\title{
Uma arquitetura da informação do processo de negócio baseada nos princípios da ontologia
}

Estudante: Reginaldo da Silveira Costa Orientador: Prof.-Dr. Cláudio Gottschalg-Duque

Brasília 


\section{Uma arquitetura da informação do processo de negócio baseada nos princípios da ontologia}

Dissertação apresentada como requisito parcial para a obtenção do título de Mestre em Ciência da Informação, pela Universidade de Brasília, Faculdade de Ciência da Informação,

Estudante: Reginaldo da Silveira Costa Orientador: Professor Dr. Cláudio Gottschalg-Duque

\section{Brasília}

2015 


\section{Uma arquitetura da informação do processo de negócio baseada nos princípios da ontologia}

\section{Banca Examinadora:}

Professor Dr. Cláudio Gottschalg-Duque / Orientador

Professora-Dra. Dulce Maria Baptista - UnB/FCI

Professora-Dra: Raquel Dias - ITA - São José dos Campos/SP

Membro Suplente: Professor-Dr. André Porto Ancona Lopez - UnB/FCI 


\section{REGINALDO DA SILVEIRA COSTA}

\section{Uma arquitetura da informação do processo de negócio Baseada nos princípios da ontologia}

Esta Dissertação foi julgada adequada para obtenção do título de "Mestre em Ciência da Informação" e aprovado em sua forma final pelo Programa de Pós-Graduação em Ciência da Informação, da Faculdade de Ciência da Informação da Universidade de Brasília.

Data da aprovação:

Prof. Dr.

Banca Examinadora:

Professor Dr. Cláudio Gottschalg-Duque / Orientador - UnB/FCI

Professora-Dra. Dulce Maria Baptista - UnB/FCI

Professora-Dra: Raquel Dias

ITA - Instituto Tecnológico da Aeronáutica

São José dos Campos/SP

Professor-Dr André Porto Ancona Lopez - UnB/FCI - Membro

Suplente 


\section{DEDICATÓRIA}

Dedico este trabalho aos meus filhos Iris, Gabriel e Taynara À minha família. Aos meus irmãos e irmãs, vivos e ausentes, pois a vida deles ecoa em meu coração. Aos meus pais, onde quer que estejam. Aos meus alunos. Aos amigos. Aos que representaram qualquer adversidade em meu caminho. 


\section{Agradecimentos}

Tanto e a tantos que agradecer!

À Deus, nos limites da minha compreensão humana, pelo impulso que traz para que a minha existência tão transitória e limitada seja ungida de uma felicidade como esta!

À minha esposa Dayse por seu amor e compreensão ao meu trabalho.

Ao meu orientador, Professor-Dr. Cláudio Duque, pois sua solidariedade, estimulo e apoio foram vitais, no sentido mais literal, para esta Dissertação.

À Professora Dulce Baptista, que se tornou para mim um referencial de competência, vitalidade e de humildade, só menores do que o carinho com que se dedica a apoiar os discentes que cruzam seu caminho! Muitíssimo grato, Mestra Gentil e verdadeira!

À Professora Raquel, sempre atenta e obstinada para emprestar sua competência, sua atenção e seu carinho a uma causa!

A minha amiga Nádima Nascimento, sempre parceira e amiga sem limites para ajudar. Aos meus alunos tanto da graduação, quanto da Capoeira, a vocês minha gratidão, pois de vocês um grande estímulo sempre me tocou o coração e a mente!

Aos professores da FCI que se desdobraram em oferecer seus saberes por amor à Ciência acima de qualquer outro interesse.

As nossas prestativas apoiadoras na Secretaria da Faculdade. 


\section{Resumo}

Esta pesquisa trata da arquitetura da informação relativa a processo de negócio, sendo seu eixo central o desenvolvimento de um modelo de representação baseado em ontologia obtida a partir do processo e conceitos que versam sobre o tema. A pesquisa é justificada pela importância do conceito de processo de negócio como um fenômeno de grande impacto nas organizações em geral, sendo o interesse focal a organização e o fluxo de informações que gravitam em torno do tema, sob a ótica da arquitetura da informação. O projeto propõe a utilização de alguns elementos obtidos nos princípios norteadores da construção de ontologias, obtendo a representação semântica do conceito em textos pesquisados, tanto quanto na opinião e sugestões dos profissionais que trabalham como analistas de sistemas, consultores ou que de algum modo vivenciam experiências na lida com o segmento de processo de negócio. A pesquisa busca produzir um modelo genérico e didático da Arquitetura da Informação do processo de negócio, que sintetize semântica e ontologicamente as características mais genéricas e os atributos fundamentais do processo de negócio, baseando-se na construção de uma ontologia-leve, obtida, utilizando-se da construção de uma taxonomia navegacional. A ontologia proposta é submetida a alguns profissionais com atuação direta em processo de negócio e, por eles, é avaliada, e depois utilizada para a construção de uma visão arquitetural do fenômeno, que é encontrado como objeto de interesse de estudos, tanto do mercado de tecnologia da informação, quanto na produção acadêmica. A pesquisa busca, assim, apreender e desvelar o processo de negócio, a partir da noção do que se tornou um plano de fundo implícito com essa denominação de processo de negócio, em diversos contextos, que esta pesquisa busca estudar e compreender.

Palavras-chave: Arquitetura da Informação, Processo de Negócio, modelos informacionais, Ontologia. 


\begin{abstract}
This research deals with the information architecture from business process, with its central axis the development of a model of representation based on ontology, obtained from the process and concepts that deal with the subject. The research is justified on the importance of the concept of business process as a phenomenon of great impact in organizations in general, being the focal interest organization and the flow of information revolving around the theme from the perspective of information architecture. The project proposes the use of some elements obtained in the guiding principles of ontology construction, obtaining the semantic representation of the concept in texts found, as much as in the opinion and suggestions from professionals working as systems analysts, consultants or that somehow in touch with experiences in dealing with the business process segment. The research seeks to produce a generic and didactic model of the architecture of business process information, summarizing semantic and ontological the most generic features and the fundamental attributes of the business process, based on the construction of an ontology-light, then using it to the building a navigational taxonomy. The ontology proposal is evaluated by some professional acting directly in the business process and they are evaluated and then used for the construction of an architectural vision of the phenomenon, which is found as a growing interest in studies of both the information technology market as the academic production. The research aims thus seize and uncover the business process, from the notion of what has become an implicit background with that name in the business process, in different contexts, this research seeks to study and understand.
\end{abstract}

Keywords: Information Architecture, Business Process, informational models, Ontology. 


\section{LISTA DE ILUSTRAÇÕES}

Figura 01 - Ciclo de vida do processo de negócio, pág. 29.

Figura 02 - Abordagem orientada a requisitos, pág. 34.

Figura 03 - Arquitetura corporativa centrada na Governança, pág. 35.

Figura 04 - Arquitetura influenciada pela SOA, pág. 37.

Figura 05 - Organização orientada por serviços, pág. 39.

Figura 06 - Mapa de processos RGB, pág. 54.

Figura 07 - Imagem do Formulário de Avaliação Terminológica, pág. 63.

Figura 08 - Arquitetura do Processo de Negócio I, pág. 87.

Figura 09 - Rich Picture do Processo de Negócio, pág. 89.

Figura 10 - Arvore hiperbólica do processo de negócio, pág. 91.

\section{LISTA DE TABELAS}

Tabela I - Tipos de Processos Segundo a Rummler Bräscher Group, pág. 53. 


\section{LISTA DE ABREVIATURAS E SIGLAS}

PPGCinf - Programa de Pós-Graduação em Ciência da Informação

CI - Ciência da Informação

TR - Teoria da Relevância

AI - Arquitetura da Informação

ABPMP - Association of Business Process Management Professional

BCE - Biblioteca Central dos Estudantes

BPM - Business Process Manager

BPMn - Business Process Manager Notation

CPAI - Centro de Pesquisas em Arquitetura da Informação

SOA - Service Oriented Architecture

FCI - Faculdade de Ciências da Informação

UnB- Universidade de Brasília

WfMC - Workflow Management Coalition

IBM - International Business Machine

GED - Gerenciamento Eletrônico de Documentos

ECM - Enterprise Content Manager

ERM - Enterprise Resource Management

TI - Tecnologia da Informação

RBG - Rummer Bräscher Geary

XML - EXtensible Markup Language

DTD - Document Type Definition 


\section{SUMÁRIO}

Item

Título

Página

LISTA DE ILUSTRAÇÕES / LISTA DE TABELAS.....................................

LISTA DE ABREVIATURA E SIGLAS...................................................... 10

$\begin{array}{lr}\text { CAPÍTULO I } & 13\end{array}$

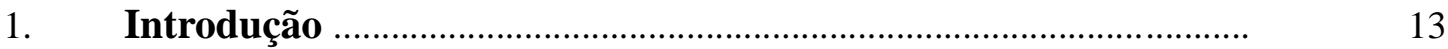

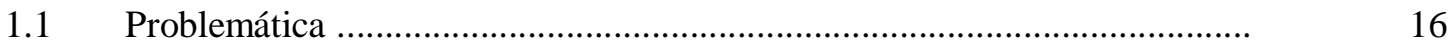

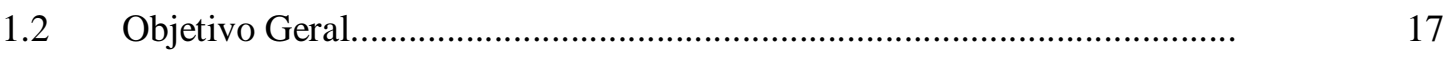

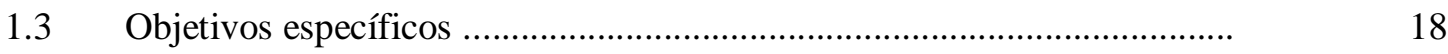

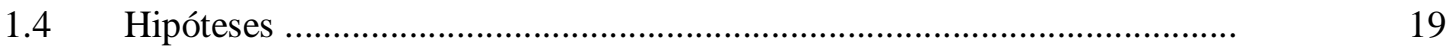

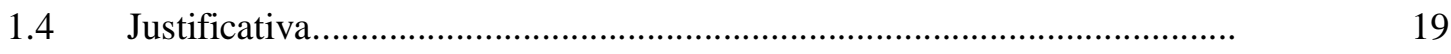

$\begin{array}{ll}\text { CAPÍt ULO II } & 25\end{array}$

2. Revisão Teórica................................................................ 25

2.1 Elementos de uma arquitetura orientada por serviços............................... 36

2.2 Elementos Multimodais do processo de negócio.......................................

2.3 Elementos da Teoria da Relevância 42

2.4 Experiências de campo - observador-participante..................................... 43

$\begin{array}{ll}\text { CAPÍTULO III } & 48\end{array}$

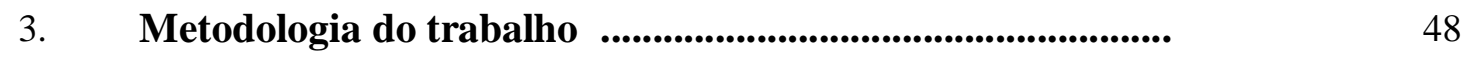

3.1 Metodologias de mercado para o processo de negócio............................... 53

3.2 Métodos e ferramentas para representação de modelos arquiteturais $\quad 57$

$\begin{array}{ll}\text { CAPÍtULO IV } & 58\end{array}$

4. Resultados da Pesquisa....................................................................... 58

4.1 Pesquisa Empírica - Descrição e relatos................................................... 58

4.1.1 A descrição de um objeto multidimensional e multifacetado............. 60

4.1.2 Representação de uma estrutura Ontológica........................................ 62 
4.1.3 Taxonomia Navegacional ......................................................... 63

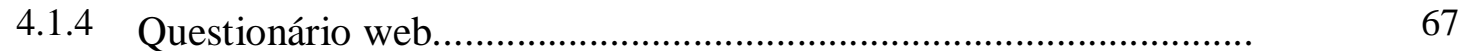

4.2 Resumos da Pesquisa.................................................................................

4.3 Uma Arquitetura da Informação do Processo de Negócio 87

4.3.1 Arquitetura da Informação do Processo de Negócio II 89

4.3.2 Uma arquitetura em rede......................................................... $\quad 90$

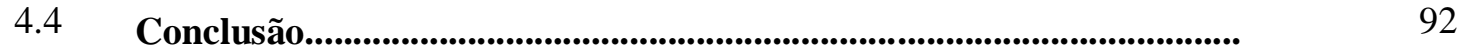

5. REFERÊNCIAS BIBLIOGRÁFICAS ....................................... 96

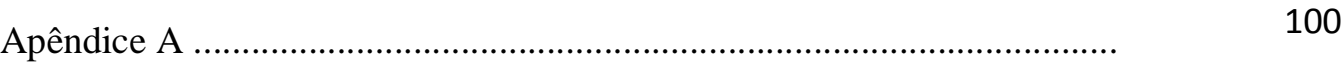

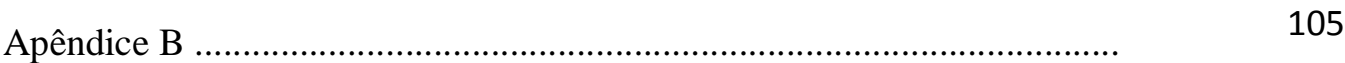




\section{CAPÍtULO I.}

\section{Introdução}

Quando o conhecimento se converte em informação, mediante os processos de codificação, ele pode fluir livremente no espaço e no tempo.

J. Robredo (2003)

Diante da abrangência e celeridade das mudanças no contexto no qual a Ciência da Informação se insere, tendo a informação como principal objeto e caracterizando-se como sua clientela toda uma "sociedade da informação", onde se encontra o primado da economia do conhecimento (TARAPANOFF, 2006), os desafios se acumulam e os pesquisadores e coordenadores de processos acadêmicos, a cada dia, buscam novos insights para oferecerem respostas, propostas e, implicitamente, soluções para essa avalanche de novas necessidades que representa a dita sociedade da informação.

Um modelo de organização que a cada dia cresce e oferece um estimulante tema para novos estudos repousa no conceito de "processo" (ROBREDO, 2003), embora tal conceito seja amplo e não claramente definido em sua caracterização, pelo autor (Da Ciência da Informação Revisitada aos Sistemas Humanos de Informação. Brasília. Thesaurus. 2003), que apenas o cita en passant em sua obra referencial para a definição de uma proposta de identidade para a ciência da informação.

Também foram encontrados exemplos de pesquisas cujo interesse foca os "processos de inovação", como é o caso da tese de doutorado defendida na Faculdade de Ciência da Informação da UnB, no Centro de Pesquisa da Arquitetura da Informação - CPAI, a qual, segundo o autor "se consolida em um modelo de Arquitetura da Informação, construída sob a orientação da proposta da Escola de Brasília, que se fundamenta nos princípios da fenomenologia hermenêutica" (OLIVEIRA, 2012). 
Outros aspectos e abordagens da Arquitetura da Informação podem ainda ser considerados, tais como o fato de ela ser um conjunto de elementos de diversas disciplinas e áreas de conhecimento, como da Biblioteconomia, Gestão e Ciência da Informação, unindo conceitos e habilidades que são incorporadas a ela a partir de fontes como design de interação, engenharia de usabilidade, comunicação, etnografia, psicologia da informação, modelagem de objetos e outras (PAIVA, 2012), o que não excluiria ainda a dimensão dos estudos da Linguística ou da Engenharia do Conhecimento (DZIEKANIAK et all, 2011).

Encontram-se ainda atualmente outros contextos onde o conceito de processo de negócio é empregado, entre eles, para citar alguns, estão: nos processos organizacionais (TARAPANOF, 2006); processos de construção, comunicação e uso da informação (CASTRO, 003, apud GUMIEIRO, 2009); processos decisórios (ALBAGLI, 1996); isso sem considerar o universo dos produtos-conceito que a indústria da informática oferece ou anuncia comumente, envolvendo o chamado "processo de negócio".

Diante desses exemplos, entre outros tantos que são focados ou citados no decorrer desta pesquisa, pode-se perceber que tais processos incluem questões tanto científico-epistemológicas, quanto abrigam demandas da chamada sociedade da informação, que por sua vez redunda em impactos criados e supridos pelo mercado da tecnologia da informação e, sob esse prisma tornam-se revestidos, portanto, de interesse social, o que os torna, também, por pressuposto, de interesse da ciência.

Epistemologicamente poder-se-ia ponderar sobre a ambiguidade do conceito processo de negócio, e o seu provável interesse para um debate dentro da $\mathrm{CI}$, o que aqui se propõe refletir-se, haja vista uma possível veia desse conceito como uma forma genérica - lato senso, portanto - de essa expressão abrigar um interessante modus operandi na organização das informações de um sem número de situações, pois o conceito se reveste de uma série de possibilidade, diversas das quais são mostradas neste estudo e ao mesmo tempo o conceito guarda diversas outras possibilidades, como se buscará ser demonstrado na presente pesquisa.

A intenção desta pesquisa, também, é buscar compreender, sistematizar e apresentar resultados que ofereçam contribuições para a apropriação do "processo de negócio" enquanto um universo temático compatível com os fundamentos da organização da informação, além de, no caso deste trabalho, ser norteado pelo uso de arquitetura da informação como modo de representação de diversos exemplos de estudos, particularmente estruturando esses exemplos em sua maioria empíricos, pela natureza do próprio objeto de estudo, ao lado da busca de sua 
origem etimológica, buscando-se modelos baseados em suas ontologias e seus elementos semânticos (HEPP, 2007).

Esta pesquisa se reveste do caráter bibliográfico, enquanto sua busca pela explicitação do fenômeno processo de negócio no contexto de uma série de estudos, onde esse conceito se acha posto de maneira quase sempre implícita, não havendo ao que percebeu o autor, estudos que busquem o seu significado semântico e ontológico, que é o interesse deste Estudo.

Os estudos sobre o processo de negócio, no entanto, requerem uma incursão inevitável no terreno da sua compreensão como um fenômeno empírico, na formatação de exemplos e na exploração de modelos que possam exprimir de maneira efetiva sua aderência ao uso dos instrumentos disponíveis no universo da Arquitetura da Informação e mesmo de ferramentas que são utilizadas para aplicação dos exemplos demonstrados no estudo, que incluem o software Treebolic, o qual é produzido e gentilmente compartilhado pelo consórcio Forceforge.net, sendo esse artefato utilizado para uma representação de arquitetura navegável em rede do conceito, bem como sua validade junto a especialistas que participarão do processo de validação dos conceitos e atributos aqui levantados.

O estudo está organizado da seguinte forma: Capítulo I, que oferece uma introdução ao assunto, latu sensu; define o problema, o objeto de estudo e as justificativas da pesquisa; no Capítulo II, são apresentados os resultados da pesquisa no campo dos referenciais teóricos e dos marcos teóricos sobre o tema. No Capítulo III, são apresentadas as bases metodológicas do trabalho e o cronograma do desenvolvimento da pesquisa. No Capítulo IV, foram registrados os resultados obtidos na pesquisa, bem como sua análise e a apropriação desses resultados para a produção de artefatos de arquitetura da informação aqui propostas; no Capítulo V, encontram-se as referências bibliográficas e outras referências utilizadas ou apropriadas no presente estudo. 


\subsection{Problemática}

Sempre existe uma apreensão natural quanto a aderência de um problema envolvendo questões de natureza abrangente como o que trata esta pesquisa, assim sendo entende-se como válido a citação a seguir, na qual se observa que os problemas que se acolhe, tanto despertam, quanto desafiam os limites de um trabalho acadêmico no âmbito da CI: “... we are not students of some subject matter but students of problems (...)" (POPPER, 1972 apud SERACEVIC, 1995). E problemas, destaca, podem cruzar fronteiras de um assunto ou disciplina.

Portanto, os conceitos e as peculiaridades de que se revestem o processo de negócio, encontram-se como uma natural interdisciplinaridade, sendo pouco provável que se possa debatê-lo, sem que se admita essa premissa.

A adoção de estudos e modelos desde a introdução do conceito de "arquitetura da informação" (WURMAN, 1997), se proliferou, se expandiu e se multiplicou em inúmeras produções e novas aplicações do próprio conceito, o qual vem se tornando uma das importantes inovações que a Ciência da Informação passou a adotar, o que trouxe novas propostas e facetas na formatação de modelos e soluções relacionadas aos espaços informacionais, vinculados principalmente com a Organização da Informação, segmento da CI que possui diversas missões e direções de desenvolvimento.

Na ciência da informação, os processos de negócios tem sido objeto de eventos que tratam especificamente desse tema, e reúnem representantes, tanto do ambiente acadêmico, quanto de empresas privadas e estatais, sendo uma premissa desta proposta de pesquisa, que existem perspectivas e potencial interesse no tema, exemplo disso há o registro de que em dezembro de 2011, foi realizado o $4^{\circ}$ Intercambio de Processos Organizacionais, demonstrando que esse tema faz parte do elenco de interesses das ciências da informação, nesse caso através do grupo de estudos CPAI (Centro de Pesquisas em Arquitetura da Informação), que promove referidos conclaves, apenas para mencionar um dos núcleos existentes de estudos do tema, sem excluir outros estudos existentes, tanto na própria FCI quando em outras áreas e unidades da Universidade de Brasília e também de outras universidades, no Brasil e no exterior.

Admitida a premissa do interesse do tema ao foro das questões da CI, caberá então ter-se uma abordam que permita uma incursão no tema do processo de negócio, como 
elemento do interesse da área de organização da informação e dela a premissa de que grande parte da informação em uso, ou seja, no curso de sua vida útil, como elemento de tomada de decisão, seja operacional ou executiva, administrativa ou acadêmica esteja implícita ou explicitamente dentro de um fluxo de informação e, portanto, de modo genericamente tácito (NONAKA e TAKEUCHI, 2003) dentro de um processo de utilização da informação.

A premissa é de que processo de negócio possa ser encontrado em qualquer natureza de instituição, portanto cabe a esta dissertação buscar uma representação ontológica que seja a fundação semântica mais abrangente possível do processo de negócio em nosso universo de temas disponíveis.

A presente proposta de pesquisa acadêmica busca, assim, enfocar como problema central e geral de trabalho, a seguinte questão:

$\checkmark$ Que Arquitetura da informação do fenômeno processo de negócio, pode ser demonstrada a partir de seus elementos ontológicos e semânticos?

Como questões específicas a pesquisa irá buscar respostas para as seguintes questões específicas:

$\checkmark$ Como utilizar um modelo de representação que demonstre o processo de negócio enquanto um sistema conceitual informal? (SCHIESSL e BRÄSCHER, 2012).

$\checkmark$ Quais atributos e classes que definem um processo de negócio como conceito, ou modelo de organização da informação?

$\checkmark$ Como representar graficamente uma arquitetura da informação do processo de negócio, baseando-se em seus elementos ontológicos?

\subsection{Objetivo Geral}

O objetivo da pesquisa é desenvolver estudos que permitam a compreensão do processo de negócio, através de modelo baseado em ontologias (classes, propriedades e relacionamentos de metadados), a partir do que, busca-se sua representação, seguindo as premissas, e as orientações da arquitetura da informação, sendo esse enfoque obtido na perspectiva da Ciência da Informação, e para tal empreender uma revisão prospectiva na literatura e nos marcos teóricos disponíveis no universo acadêmico, mormente - mas não 
necessariamente - na produção brasileira, bem como do uso do conceito em abordagens típicas existentes no mercado da tecnologia da informação, dos serviços de consultoria e na ação dos profissionais de "engenharia de processos", visando compreender o chamado "processo de negócio" e suas apropriações em produtos e serviços no mercado, tanto quanto em estudos e pesquisas do universo acadêmico.

De modo resumido, o objetivo geral poderá ser definido como:

Um estudo do fenômeno do processo de negócio como conceito de organização da informação, através de elementos de sua ontologia, visando a construção de uma arquitetura de informação sobre o tema.

\subsection{Objetivos Específicos:}

Como objetivos específicos a pesquisa deverá:

$\checkmark \quad$ Produzir e validar o processo de negócio através de modelo semântico e ontológico, através da inteiração com profissionais e especialistas que atuam no segmento de mercado da engenharia de processos.

$\checkmark \quad$ Desenhar modelo que permita a compreensão do processo de negócio em sua dimensão semântica e ontológica, trazendo o fenômeno para o campo das representações da organização da informação; e, ainda,

$\checkmark$ Desenvolver uma arquitetura da informação, após empreender ações tais como o "escutar, o construir, o habitar e o pensar a informação como atividade de fundamento de ligação hermenêutica de espaços, desenhados ontologicamente” (LIMA-MARQUES \& MACEDO, 2006, pág. 245), relativamente ao fenômeno processo de negócio. 


\subsection{Hipóteses}

As hipóteses que resumem a expectativa dessa pesquisa, são as seguintes:

$\checkmark$ O fenômeno objeto desta pesquisa, processo de negócio, estaria estreitamente ligado a questão epistemológica da organização da informação;

$\checkmark$ Os elementos da taxonomia navegacional e da ontologia apoiariam a construção da organização da informação do fenômeno;

$\checkmark$ A arquitetura da informação seria uma forma de representação que ajudaria na compreensão do fenômeno.

\subsection{Justificativa}

Demandas latentes podem ser reconhecidas e colhidas no campo do processo de negócio, as quais são debatidas constantemente no front das empresas e setores internos de tecnologia da informação, mormente em pesquisas e projetos patrocinados pelo interesse da indústria da informática.

Nesse sentido o fenômeno está estreitamente ligado ao modus operandi da construção de espaços organizados de informação e, portanto, a sua arquitetura no sentido definido por Wurman (1997), cabendo nesse modelo de apropriação as dimensões de problema enquanto um problema e nele a caracterização ou identificação de quatro variáveis que seriam: i) recursos; ii) heurísticas; iii) controle e iv) concepções, percepções e pré-conceitos (SCHOENFELD, 1985a, apud PINTO, 2003), pois o desenho de arquiteturas nesse contexto pressupõe a disponibilidade de condições mínimas através dos quais se possa programar de maneira lógica e, portanto, compatível com as necessidades e exigências dos computadores.

$\mathrm{Na}$ tecnologia da informação, portanto, o problema tem uma série de faces que são exploradas segundo critérios que atendam ao mercado, naturalmente, mas nem por isso menos extensivo o debate em torno do processo de negócio enquanto fenômeno de interesse, tanto quanto pela busca de padrões e de definições que o livre ou minimize da presença dos verbetes ambíguos dentro do vocabulário da TI.

Para tanto diversos movimentos buscam unificar os conceitos por trás do processo de negócio, através do debate que visa, principalmente, estabelecer métricas e padrões que permitam a convivência entre tecnologias distintas, sem roubar-lhes a originalidade, mas que, 
ao mesmo tempo, lhes aufira a condições de tecnologia consolidada e perfeitamente sedimentada nos balcões de soluções tecnológicas para atender aos problemas das instituições. Tanto é assim, que se encontra em plena atividade, a ABPMP - Association of Business Process Management Professional ${ }^{1}$, que busca a definição de padrões, compartilhamento de melhores práticas, a certificação, além do treinamento técnico de profissionais, desenvolvendo diversos fóruns a nível nacional e internacional, e neles buscando a adesão de novos associados, bem como a propagação dos padrões e definições ali produzidas.

$\mathrm{Na}$ Ciência da Informação, os conceitos e métodos desenvolvidos em estudos relativos ao processo de negócio não mantêm, necessariamente, alguma paridade ou produção em número e grau de abrangência do problema, como aqui identificado, visando fazer frente a essas demandas, seja por outras prioridades nas pesquisas, seja pelo insuficiente efetivo de pesquisadores que se dedicam as questões relativas a essa natureza de assunto, ou mesmo pela absoluta falta de prioridade que o tema desperte em trabalhos conhecidos na CI,

É sabido, entretanto, que existe um ritmo com o qual a indústria identifica nos contextos de mercado a possibilidade de obtenção de lucros, numa eterna corrida pelo lançamento de novas soluções e produtos, sem respaldo ou correspondência de interesse do front acadêmico, correndo ambos esses processos à revelia um do outro.

Uma premissa da proposta desta pesquisa é de que a abordagem utilizada para modelagem do processo de negócio, como elemento de suporte à compreensão da realidade informacional das organizações, traga contribuições para a melhoria de seu entendimento e também ajude na formulação de diagnósticos e proposições de alternativas para aperfeiçoar ou criar novos modelos de informação e, nesse sentido, ofereça suporte à organização da informação do processo de negócio, latu senso.

Justificativas, no entanto, não nasceriam certamente de um apanhado de razões aleatórias dentro do contexto da explosão de um tema em profusão no universo da produção acadêmica.

Por isso, destacam-se, aqui, experiências profissionais do autor desta dissertação, além das pesquisas bibliográficas e estudos acadêmicos com o tema, estrito senso, como parte dos impulsos que levaram a esta pesquisa, isso reporta ao fato de que a própria escolha de um tema/problema traga inevitavelmente uma carga de escolhas ou de experiências acumuladas,

${ }^{1}$ www.abpmp-br.org 
sendo inviável negar-se tal premissa, como também desnecessária tal negação (TOMANIK, 2004).

Uma justificativa fundamental desta dissertação se acha na premissa de que as demais produções conhecidas e recolhidas durante a realização deste estudo (havendo uma óbvia despretensão de poder-se abarcar-se todo o universo de produções existentes), fato é que até o presente momento, nenhum estudo foi identificado como uma contribuição que esmiuçasse os atributos de processo de negócio em sua plenitude de significado, ou pelo menos oferecesse um determinado valor ao conceito, semântica ou ontologicamente falando, que é a proposta deste trabalho.

A produção de modelos que represente as meta-informações do processo de negócio, portanto, se justificaria pelas inúmeras relações com o tema e, de fato, os modelos ontológicos são justificados pelo valor que agregam aos objetos estudados, emprestando-lhes maior clareza e facilidade de organização, dentro de seu espaço de existência ou mesmo para sua compreensão por atores mais distanciados do fenômeno, uma vez que ontologias são utilizadas atualmente em diversas áreas para organizar a informação, conforme ratificado por diversos autores entre os quais alguns já foram citados, havendo ainda estudos de Bateman, 1996; Borgo et alii, 1997; Aguado et alii, 1998; Domingue, 1998; Hasman et alii, 1999; Shum; Motta \& Domingue, 2000; Leger et alii, 2000; Kalfoglou, 2001; Vázquez, Valera \& Bellido, 2001; Gandon, 2001; Martin \& Eklund, 2001; Alexaki et alii, 2002 (apud ALMEIDA et PAX, 2003).

A arquitetura da informação, por sua vez, em dado momento de sua história, é apropriada para apoiar e sofre adaptações para as questões relacionadas com a Ciência da Informação, contexto no qual é sua aplicação ambientada a contextos onde possa ajudar a identificar a necessidade de organização da informação e, para tanto, possui como mediação os pilares do "escutar, o construir, o habitar e o pensar a informação como atividade de fundamento de ligação hermenêutica de espaços, desenhados ontologicamente" (LIMA-MARQUES \& MACEDO, 2006, pág. 245)

Nesse sentido, a arquitetura da informação aplicada à compreensão do fenômeno processo de negócio, se reveste da possibilidade e de apoio no sentido de se permitir uma forma de trazer o problema para o âmbito da Ciência da Informação, haja vista a complexidade existente decorrente da ambiguidade e da abrangência do tema, o qual se estende desde uma forma elementar de um fluxo de informação básico, até as mais variadas questões de 
organização do conhecimento de uma instituição de múltiplas funcionalidades e inúmeras facetas e critérios.

A AI seria uma maneira de simplificar os significados do processo de negócio, tornando-o algo compreensivo e sistematicamente visualizado.

Uma ontologia, por sua vez, tem diversas utilidades (SCHIESSL e BRÄSCHER, 2012), sendo que para o propósito desta dissertação ela servirá como subsídios para a futura construção de um sistema conceitual informal e também como uma especificação de uma conceitualização (pág. 127) o mais abrangente possível.

\subsubsection{Adoção das Ontologias}

A Ontologia tem principalmente a função de permitir um nível de organização e sumarização de conceitos, de sorte a torná-los imbuídos de uma forma sistêmica, onde se minimize ou se faça desaparecer a ambiguidade, para se classificar áreas de conhecimento e seus universos informacionais, apoiando, portanto, a organização da informação sobre um fenômeno, no caso o processo de negócio.

A Ontolog-Forun é uma comunidade virtual que vem trabalhando no desenvolvimento dos conceitos de acervos ontológicos ${ }^{2}$, nela vem se desenvolvendo atividades colaborativas por centenas de pesquisadores, participantes, de diversos países, desde o início do ano de 2000, já estando bastante consolidadas diversas ações que a comunidade vem empreendendo, para eles uma ontologia "define os itens usados para descrever ou representar uma área de conhecimentos".

Mas, principalmente, o objetivo dessa comunidade se refere ao uso em ambiente computacional, por isso para eles as ontologias "compreendem as definições de computador utilizável de conceitos básicos em um domínio e os relacionamentos entre esses conceitos”, tornando-se assim uma maneira para tornar o próprio processamento semântico uma realidade, já que a ambiguidade é sua maior inimiga (SCHIESSL e BRÄSCHER, 2012).

A missão empreendida pela Arquitetura da Informação, por outro lado, se refere do mesmo modo, à busca da melhor forma de organizar um espaço informacional, além de têla também, a informação, como parte dos riscos inerentes à ineficiência ou ineficácia dos

\footnotetext{
${ }^{2}$ http://ontolog.cim3.net/
} 
modelos arquiteturais adotados, haja vista os impactos com que a ambiguidade afeta os protótipos ou os modelos desenvolvidos.

Embora outras conquistas de padrões já tenham se efetivado, tanto no mundo da ciência da computação, quanto na ciência da informação, tais padrões são sempre postos a prova, trazendo sempre novas exigências e necessidades que fazem o processo de construção de modelos de organização da informação tornarem-se cada vez mais evoluídos, mas, nem por isso capazes de eliminar a sobrecarga de informações que são produzidas e acumuladas nos processos acervos das empresas e quaisquer outros cenários informacionais, tanto quanto nos núcleos de pesquisas.

Um desses padrões francamente adotado no universo das ciências da computação, tanto quanto nas tecnologias de mercado, seria o XML (EXtensible Markup Language), que é utilizado para a descrição dos dados (portanto, metadados), que se tornou uma solução que permite a integração de bases e processos informatizados de diferentes organizações, sendo esse padrão plenamente aceito, ao lado de outros recursos a ele anexados, como é o caso do DTD (Document Type Definition), cuja proposta é definir os requerimentos de construção de blocos de processos dentro de um documento tipo $\mathrm{XML}^{3}$, que de forma confiável e padronizada permite compreender o significado de novos vocábulos e automaticamente identificar o comportamento apropriado para o tratamento das bibliotecas de metadados, que são assim suportadas e levadas para o universo semântico de processos automáticos.

As ontologias, por outro lado, são, geralmente, expressas utilizando-se de uma linguagem de base lógica, sempre mais abrangente, mais precisa e consistente, cujas definições significativas podem ser feitas utilizando atributos como classe, propriedade e relações.

Por isso, as aplicações que se utilizam de ontologias podem ser consideradas inteligentes, no sentido de que podem oferecer mecanismos para funcionar com muito mais precisão no nível conceitual.

A palavra ontologia no contexto da tecnologia da informação tem sido utilizada para descrever artefatos com diferentes graus de estrutura, algumas delas do tipo taxonomias simples, para classificar, organizar e sistematizar os metadados de uma base informacional.

Mais formalizadas, as ontologias especificam descrições para os seguintes conceitos:

Classes - (objetos genéricos) em diversos domínios de interesse;

\footnotetext{
${ }^{3}$ http://www.w3schools.com/dtd/
} 
Relacionamento - os que existam entre as classes, que traduzem as tipologias dos fluxos no que diz respeito às ações que ocorrem; e

Propriedades - também conhecido como atributo, que são os primados do que deve existir nas classes.

$\mathrm{Na}$ ciência da informação, existem consagrados diversos tipos de estruturas utilizadas para a organização da informação, entre as quais: glossários, dicionários, e também os que organizam com a criação de categorias que são os cabeçalhos de assunto e os esquemas de classificação (ou taxonomias). Outras bases se organizam a partir dos conceitos e seus relacionamentos, que são as ontologias, os tesauros e as redes semânticas (ALMEIDA et PAX, 2003).

As ontologias têm sido utilizadas para a organização de conteúdos de fontes de dados. Ela é criada por contribuições de especialistas e definem as regras que regulam a combinação entre os termos e suas relações em um determinado domínio de conhecimento.

A ideia central da ontologia seria justamente atingir o mais próximo possível a abstração que existe na mente do usuário dos sistemas de informação, ajudando na eficácia de recuperação da informação pretendida. Trata-se, por assim dizer, de um refinamento no conceito de meta-informação que, assim, permite menos desperdício de tempo das pessoas quando desejarem um determinado conceito.

Naturalmente, desde os primórdios da organização da informação, o que se busca é justamente um modelo cada vez mais eficiente e eficaz de recuperação de informações, dispostas de maneira a serem mais facilmente recuperada, haja vista o turbilhão de crescentes volumes que atingem as bases informacionais a cada dia.

Assim sendo, considera-se que o volume de usos e as abrangências expressas nos processo de negócio seriam justificativas plausíveis para que esta pesquisa se desenvolvesse, e oferecesse contribuições na tipologia, nas classificações, nos metadados e em tantas outras formas de apropriação do conceito de "processo de negócio" que, para ser atingido optou-se pela proposição de modelos inspirados nas formas expressas pelas ontologias, e formatados, segundo o modus operandi da arquitetura da informação, visando expressar a compreensão do objeto deste estudo, de maneira adjetiva e substantiva dos processo de negócio, em suas diversas embalagens teóricas, ou empíricas. 


\section{CAPÍtULO II.}

\section{Revisão Teórica}

Como processo de negócios, para efeito desta pesquisa, entende-se as diversas naturezas de "negócio", tanto aqueles que são normalmente privilegiados como interesse de mercado da indústria da informática, quanto daqueles que se caracterizam como eixo de atuação do setor governamental, do mesmo modo que o terceiro setor, onde o primeiro setor seria composto pelas organizações governamentais sem fins lucrativos; o segundo setor aquele composto pelas organizações não-governamentais com fins lucrativos e o terceiro setor o que é composto pelas organizações não governamentais sem fins lucrativos (LAVALLE et ali, 2006) ou, ainda, empresas privadas, que podem ser agrupadas de modo transversal sob a ótica do tema do seu próprio "processo de negócio".

A partir de um determinado momento, não muito claro, poder-se-ia dizer que nasce a chamada cultura do processo, não como uma estratégia isolada que passou a fazer parte dos artefatos tecnológicos ou metodológicos das empresas, mas, antes, uma abordagem crucial de análise e avaliação dos níveis de efetividade e desempenho, relacionados com o âmago da produtividade e a qualidade relativa aos fluxos de informação e de decisão dentro das empresas (COSTA et MEDEIROS, 2003).

O mapeamento revela as interferências que cada ator envolvido impõe ao fluxo produtivo, em paralelo ao fluxo informacional, evidenciando de modo sistemático e, quando, devidamente, organizado e suportado em tecnologias afins, tornando-se mensurável, capaz de demonstrar os setores e etapas que promovem a dinâmica dos resultados e imprime celeridade aos fluxos em contraposição aos que seguram, retém ou estrangulam o andamento efetivo da produção, quais setores ou atores contribuem para acelerar o passo dos negócios e quais o inibem ou simplesmente o paralisa. Buscando-se, diante desse quadro informacional, a solução dos problemas e a volta da efetividade ao seu eixo de normalidade ou de melhoria.

Embora útil, no entanto, pode-se notar rapidamente que essa cultura do processo traz em seu bojo não só felicidade e promoções de destaque para os atores, mas traz, também, a inevitável agrura dos controles, da transparência dos gargalos - e acaba por revelar o que, ou 
quem está por trás, ou à frente dessas etapas, e dá visibilidade ao desempenho dos atores e assim monitora os processos de gestão e ou de tecnologias adotadas.

Esse tipo de solução acaba fazendo transparecer os pontos cegos dos sistemas corporativos, onde se oferece, às vezes, o dissabor da percepção que demonstra que as chamadas soluções caseiras, aqueles pequenos sistemas desenhados com ferramentas improvisadas, planilhas e outros mecanismos, automatizados ou não, produzem impacto direto na performance dos segmentos produtivos.

Observa-se ai o fato de que os controles manuais eram, e em muitos casos ainda são, um verdadeiro tricô no meio de uma engenharia toda informatizado, ao tempo em que, justamente, nesses controles, residiam diversas decisões e ações de profundo impacto no negócio, como por exemplo, a forma como nos integramos a um fornecedor ou parceiro; onde temos mapeados, ou produzimos uma articulação de um novo caminho para um projeto ou uma solução emergencial dentro dos modelos de informação que são adotados, ou descartados dentro das organizações.

Pode-se perceber que a cultura do processo não será apenas uma nova embalagem para as velhas fórmulas utilizada pela indústria de informática, que na maioria das vezes retifica roupagens e conceitos já consagrados, incluindo novas funcionalidades, ou, simplesmente, um novo jargão para se apropriar mercadologicamente de demandas conhecidas, e oferecer novas percepções aos processos e subprocessos institucionais, seja isso um fato que afeta uma organização de natureza acadêmica, da indústria, do governo, ou outra, pois como afirma MATTOS et al.: O Processo de negócio está sendo considerado o principal fator de sustentação e aperfeiçoamento das competências centrais das organizações (MATTOS et al, 2012)

Essa cultura seria responsável por um tipo de inovação da qual provavelmente não mais poder-se-ia ficar livres: trata-se do estado-da-arte do desempenho empresarial, baseado na leitura de indicadores setoriais, os quais, depois de conhecidos, não mais seria possível desprezar ou ocultar; tais como a possibilidade (e necessidade) da substituição de soluções estanques, proprietárias, improvisadas ou casuísticas, por modelos e sistemas de informação abertos e integrados, evolutivos e principalmente que ofereçam clareza aos fluxos de informação dentro da organização.

Dentro do que passou a ser tratado como reengenharia de processos, por setores especializados do mercado da informação e de serviços técnicos específicos oferecidos no mercado para dar suporte e respostas para a estratégia corporativa, nasce a inspiração ou o meio 
de interferir positivamente nos fluxos produtivos ou decisórios, tanto quanto na possibilidade da eliminação de passos que não contribuam para os resultados esperados ou na eliminação de outros tantos passos meramente burocráticos.

Trata-se, enfim, da gestão efetiva de uma cadeia de valores (denominação genérica atribuída ao processo de negócio, do ponto de vista de sua interferência valorada na eficiência e/ou eficácia do processo produtivo) que interfere no processo de trabalho e nos resultados corporativos.

Esse seria o fundamento inicial de uma avaliação das questões que envolvem o conceito e a abrangência do tema tratado na presente dissertação, aqui enfocado como "processo de negócio", onde se busca a compreensão da abrangência conceitual e os seus desdobramentos semânticos, e ontológicos.

Poderiam ser adicionados alguns outros fatores também importantes que estimularam o desenvolvimento desta dissertação, dentre os quais a intenção de provocar uma discussão abrangente sobre o modus operandi dentro das empresas, ao lidarem com tecnologias, modelos informacionais, conceitos, cultura e artefatos relacionados com seus "processos".

Os aspectos mais teóricos da questão debatida passam pela interpretação do fenômeno à luz da arquitetura da informação, onde o problema assume uma proposta sistêmica de compreensão, como um fenômeno business, enquanto fato objetivamente ligado às funções corporativas e institucionais de qualquer natureza - e não somente como uma questão afeta às organizações diretamente interessadas em ganhos financeiros. Com esse intuito a pesquisa busca traduzir o conceito de "negócio" enquanto algo inerente a qualquer área de atuação institucional.

Estudos debatem o processo de negócios no contexto acadêmico, no âmbito da ciência da informação, algumas das quais serão pontuadas no trabalho e servirão de interlocução teórica, conceitual ou empírica desta dissertação.

Outras contribuições e pesquisas, como a pesquisa obtida na Faculdade de Tecnologia, a dissertação de Mestrado "Contribuições para melhoria da Gestão Organizacional por intermédio de Processo de negócio", de autoria de Guilherme Pereira Souto, orientado pelo Professor-Dr. Luís Fernando Ramos Molinaro (2012), que, entre outras fontes, oferece um importante subsídio para a compreensão do espectro no qual se enquadra o objeto deste estudo, demonstrando sua transdisciplinaridade enquanto tema acadêmico.

Por outro lado, no âmbito do mercado da tecnologia da informação, principalmente no segmento de serviços de consultoria, o conceito de processo aparece como 
questão de uso estratégico, visando alavancar a produtividade nas organizações, buscando-se nos projetos os requisitos e passos necessários para sua internalização.

Os segmentos que oferecem essa natureza de serviço, enfocam o processo de negócio enquanto saber institucional necessário, pesquisam mecanismos aplicáveis, metodologias, ferramentas, instrumentos e abordagens para servir de base para a implantação de novos modelos de negócio, ou novos níveis de atuação do todo, ou parte da corporação.

Esse campo de atuação vale-se, via de regra, de ferramentas do tipo workflow, um consagrado tipo de tecnologia que automatiza os fluxos de processos além de controlar os que existem, implantando ou mudando controles sobre as regras, fluxos e ritmos de trabalho.

Também se tornaram comuns os projetos de BI - Business Intelligence, com uma proposta na qual se busca a construção de bases de informações corporativas, construindo-se os chamados "modelos multidimensionais" de dados, e nos quais são oferecidas soluções de acesso para consultas do tipo on-demand (também denominadas acesso não estruturado) aos executivos e setores estratégicos das empresas. Essa forma de tecnologia embora já existente há razoável tempo no mercado, ainda padece de uma série de limitações, particularmente, no que diz respeito aos custos, à cultura das equipes e à falta de continuidade de grande parte dos projetos iniciados.

Existem também serviços para projetos da mencionada e muito praticada reengenharia de processos, a maioria das vezes sob a responsabilidade da área de gestão de tecnologia da informação das empresas e, em alguns casos, áreas de Gestão de Processos, esses últimos principalmente, e, basicamente, em empresas de grande porte.

Assim sendo, projetos e ações que lidam diretamente com os chamados "processo de negócio" são presentes na indústria de modo e com espaços claros de aplicação, e se destinam as vezes, aos executivos de tecnologia da informação, outras vezes aos setores de planejamento estratégico.

O tema também desperta o interesse de segmentos das pesquisas acadêmicas, conforme já mencionado, como no exemplo obtido da Engenharia de Produção, que interpreta o fenômeno do processo de negócio, bem como debate o conceito de workflow Costa (2009) apresenta como dissertação de mestrado o tema: Formulação de uma metodologia de modelagem de processo de negócio para implementação de workflow, estudo com enfoque instrumental, típico ramo de estudos da área, mas que corresponde, de algum modo, ao interesse do mercado das consultorias. 
O autor oferece uma ilustração para a compreensão da combinação de elementos que compõem uma solução envolvendo o processo de negócio, tendo como intenção a sistematização da construção de workflows, os quais são, por definição, aplicáveis à praticamente qualquer área onde exista um fluxo produtivo, envolvendo informações, documentos, interferências humanas ou mesmo de processos automáticos, além do conjunto de opções que esse tipo de tecnologia oferece para os gestores do negócio, latu senso, conforme pode ser visto no modelo do estudo de Costa (2009), a seguir:

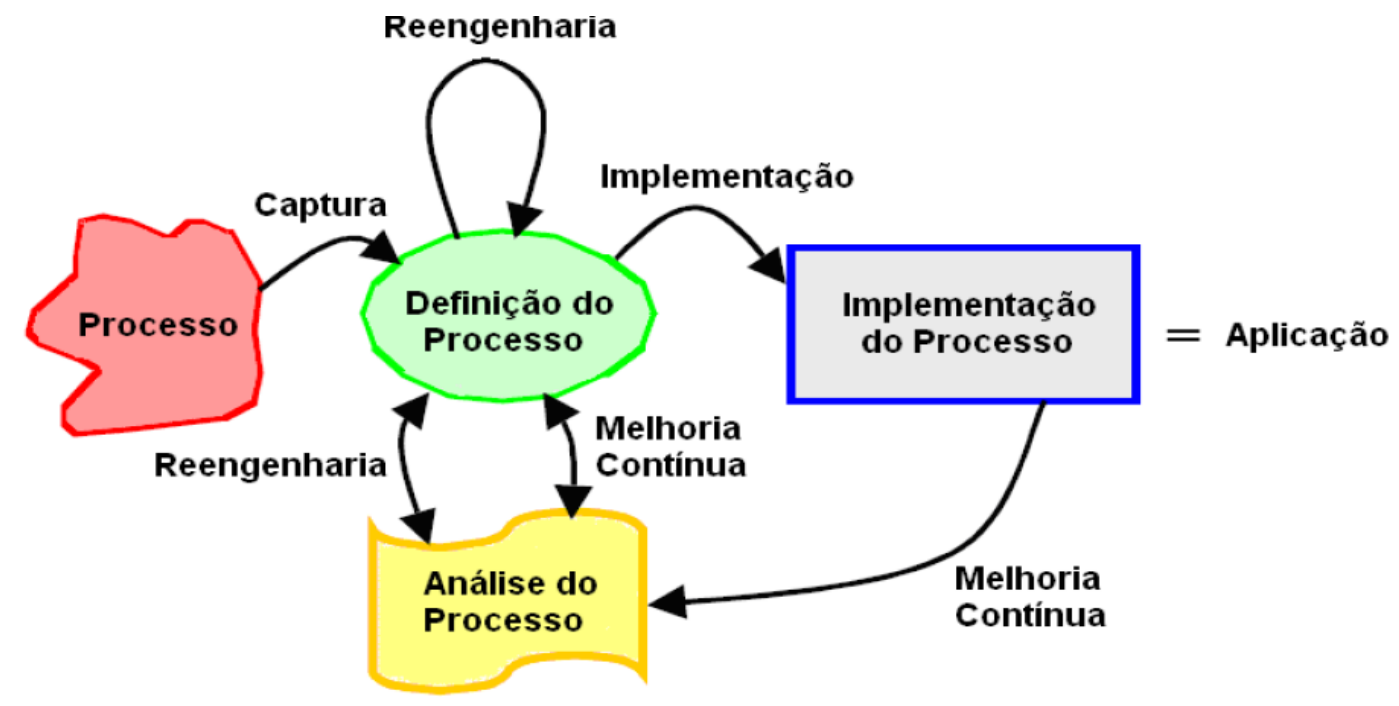

Figura 01 - Ciclo de vida do processo de negócio

Fonte: COSTA, 2009.

No modelo utilizado, o autor demonstra a articulação entre diversos conceitos presentes nesta dissertação, embora, como descrito, trate de uma pesquisa da área de Engenharia de Produção. O que se vê, portanto, é que os conceitos são comuns e isso ilustra e reforça a necessidade identificada nesta dissertação de buscar-se uma maneira de organizar essas informações, que ensejem, pela natureza da própria área de estudos na qual esta pesquisa se encontra, sua melhor classificação e compreensão, inspirada nas noções ontológicas do tema.

Destaque-se, que no bojo desta dissertação, o problema será visto e tratado pela busca de seu significado enquanto interesse da ciência da informação, da engenharia de processos, buscando entende-lo sob o ponto de vista dos profissionais e pesquisadores de disciplinas da Administração, admitindo-se que possam existir outros enfoques que não foram privilegiados no contexto deste estudo dissertativo. 
Este estudo buscará o balizamento dos atributos e conceitos que foram identificados como inerentes ao "processo de negócio" por profissionais especializados que atuam nas áreas de gestão, consultoria ou estudos diversos envolvendo abordagens empíricas principalmente, mas principalmente com atuação diretamente no processo de negócio.

O tema encontra-se debatido em grande universo de estudos, e para ilustrar a abrangência de tais estudos existentes, encontrou-se o seguinte resultado, em uma pesquisa comum via internet, através do sistema de busca "Google, em 19-SET-2014, utilizando-se a argumentação da busca como: ("processo de negócio" + tese or dissertação + PDF), a qual retornou aproximadamente $\underline{\mathbf{8 4 . 6 0 0}}$ resultados.

Modificando-se essa busca, feita na mesma data, utilizando a expressão: ("processo de negócio" + tese or dissertação + PDF + ontologia), o sistema de busca retornou aproximadamente $\underline{38.400}$ resultados.

Naturalmente essa busca não pretende ser um indicativo infométrico que possa ser usado como uma análise precisa, ou, cientificamente comprovada do universo existente de estudos e produções acadêmicas sobre o tema. Ela apenas visa oferecer ilustração e uma representação lato-sensu do provável universo empírico que também ilustra a abrangência do interesse do tema, particularmente a expressão "processo de negócio"; nota-se apenas, com a ilustração, o quanto o problema vem tornando-se, a cada dia, mais e mais estimulante, e presente como temática para o desenvolvimento de trabalhos acadêmicos, científicos e/ou tecnológicos.

Grande parte dos estudos que foram lidos e relacionados (ver bibliografia) são de instituições de ensino e pesquisa que atuam em cursos de natureza tecnológica, como sistemas de informação, ciência da computação, engenharia mecânica, engenharia de produção, etc.

Dos estudos publicados, obtidos ou exemplificados nesta dissertação, buscou-se amostras do tema do estudo lato senso, bem como de situações e conceitos que auxiliem na compreensão das questões relativas ao tema, tendo sido tais estudos parte dos subsídios empíricos e amostras, obtidas, para a busca por um conjunto de atributos, propriedades e abrangência do fenômeno observado.

Os subsídios dos estudos, artigos, teses e dissertações analisadas ofereceram expressivas contribuições ao tema, principalmente, por trazer à tona uma discussão sistêmica, as quais se buscou transportar para uma visão sustentada nos elementos de uma arquitetura da informação, tendo como função a organização das informações do tema-chave, apoiando a pesquisa nos elementos teóricos que suportam a modelagem de sistemas de informação 
(Robredo, 2003). Perseguiu-se trilhas teóricas e conceituais da Ciência da Informação, sempre que possível nas pesquisas realizadas na FCI - Faculdade de Ciência da Informação.

Buscou-se assim estudos que se relacionam diretamente com o objeto de pesquisa, que tem declarado interesse na questão do "processo de negócio", ou, alguma forma de estudo ontológico vinculado ao tema, como estudo acadêmico ou técnico, ressalvada uma certa banalização de que o conceito se revestiu no mercado e mesmo nas pesquisas acadêmicas, servindo a um sem número de interesses, visões e propósitos, conforme demonstrado pelo volume de estudos que podem ser encontrados a respeito.

Destaca-se desta análise, no que diz aos estudos que foram identificadas no universo das dissertações e teses encontradas, que, salvo melhor compreensão, admitida ainda por absoluta coerência e reconhecimento crítico e ético, os limites do acesso a toda extensão da produção existente, em nenhuma das produções obtidas, havia declarado enfoque ou tema de estudo o próprio significado do conceito de "processo de negócio", ou seja, nota-se como premissa que não se encontrou estudo análogo, no qual se questiona o sentido, a abrangência, os atributos ou o seu significado semântico, taxonômico ou ontológico, sendo esse o interesse desta dissertação, estrito senso.

Encontrou-se estudo, consignado na tese de doutorado de Jorge Cordeiro Duarte (2010), debate "Uma Arquitetura Ágil da Informação Organizacional", onde o autor parte do pressuposto de que:

As organizações atuam hoje em um ambiente caracterizado pela mudança constante e, por isso, necessitam de instrumentos que permitam agilidade para adaptar suas estratégias, processos ${ }^{4}$ e sistemas às necessidades de cada momento onde o autor afirma que a Arquitetura da Informação Organizacional (AIO) tem sido identificada por pesquisadores como a abordagem adequada para prover essa agilidade.

Nessa perspectiva de estudo, encontramos mais um importante indicativo quanto à aderência da proposta de pesquisa relacionada com a adoção de uma arquitetura da informação que aborde os processos e neles a rede de informação, os fluxos operativos de informações, dessa feita no âmbito das organizações, destinatárias de algum modo das produções da universidade, além da fronteira epistemológica acadêmica em si, outra faceta de demandas que comportariam uma abordagem dessa natureza.

\footnotetext{
${ }^{4}$ Formatação e negrito do autor desta dissertação.
} 
As premissas decorrentes das otimizações que abordam o emergente enfoque de orientação a serviço (conhecidas como SOA - Service Oriented Architecture), podem trazer grandes ganhos para o desenho de metamodelos de organizações, também serão consideradas como provável adendo para a expansão do universo abrangido pela solução das arquiteturas informacionais, consideradas sob a ótica de toda a sua densidade e efetividade teórica, com reflexos previsíveis no seu terreno de práxis.

Assim sendo, a combinação proposta no presente projeto visa integrar a visão ontológica ao processo de negócio, oferecendo essa contribuição como um insumo invulgar para o aprofundamento do reflexo da economia de processos decorrente da já impactante orientação a serviços, premissa universal de todas as formas de organização que poderá ser acolhida junto ao framework ontológico pautado nos elementos que propõe a Escola de Brasília, uma fenomenologia hermenêutica, uma proposta que pode trazer novas visões para um problema que se acha aparentemente desprezado e, portanto, "resolvido" e não plenamente estudado no âmbito da ciência da informação, proposta neste projeto.

Observando o contexto das produções e os focos de interesse da Ciência da Informação - incluindo os conteúdos e temas encontrados em resultados publicados de pesquisas, percebe-se que a questão do "processo" está diluída como parte de temas tangenciais aos artigos/palestras apresentados ali, tanto quanto pode-se verificar em outras produções correntes, entre elas, via de regra, as arquiteturas informacionais também têm sido vistas através de modelos e notações que basicamente estudam, analisam buscam revelar grandes eventos de um fluxo comunicacional, quase sempre sob uma perspectiva epistemológica ou sistêmica, ficando quase sempre para um segundo plano as apropriações que o processo permitiria, como se observa no estudo citado desenvolvido no CPAI que discute o "processo de inovação" (OLIVEIRA, 2012).

Ou seja, se levarmos em conta Le Coadic (2004, pag. 25) que afirma que esta ciência tem "por objetivo estudar a gênese, a natureza e os efeitos das informações (...) e analisar os processos de produção, comunicação e uso dessas informações" (grifo deste pesquisador), as questões relativas ao processo poderiam ser um importante tema para a ciência da informação e, assim, sê-lo também para a arquitetura da informação.

Nos exemplos de produções encontradas no âmbito dos trabalhos de alunos da FCI-UnB, encontrou-se ainda a monografia orientada pelo Professor-Doutor Mamede Lima Marques e desenvolvida por Zenilton de Jesus Gayoso de Miranda (2006), que aborda o 
"mapeamento de processos baseados em arquitetura da informação", o qual também foca o debate sobre a questão do processo no contexto da arquitetura da informação.

A análise desenvolvida no estudo de Miranda (2006), busca uma identificação da AI com o contexto de organizações, visando auxiliar a compreensão de seus processos administrativos, culturais e estratégicos frente ao pressuposto da existência de uma "convergência "epistemológica" do pensamento sistêmico, da arquitetura da informação e da teoria da coordenação pode resultar em uma base conceitual para iniciativas de mapeamento de processos".

O mundo das organizações, por outro lado, vive seu próprio critério de auto definição, onde são encontrados exemplos os mais distintos tratando o tema "processo de negócio", além das referências encontradas em foro universitário.

A abordagem orientada a processos, como por vezes são denominados os projetos que tratam nas organizações os seus processos negociais, seja visando estudo de transformação ou simples compreensão de seus problemas, vem sofrendo constantes mudanças de enfoque, tanto quanto de tipologias de abordagem, metodologias, ferramentas e fontes de referência.

Nesse universo de transformações em profusão, destacou-se neste estudo algumas das perspectivas já consolidadas, onde e como se utilizam soluções obtidas na e da tecnologia da informação, ou são desenvolvidas em setores estratégicos, nos quais se busca a administração de processos corporativos e visam sua gestão de modo efetivo.

Algumas dessas abordagens e métodos focam-se em elementos e critérios corporativos, tendo como alternativa, modelos onde o processo de negócio aparece numa posição periférica das abordagens, tais como o modelo ilustrado a seguir: 


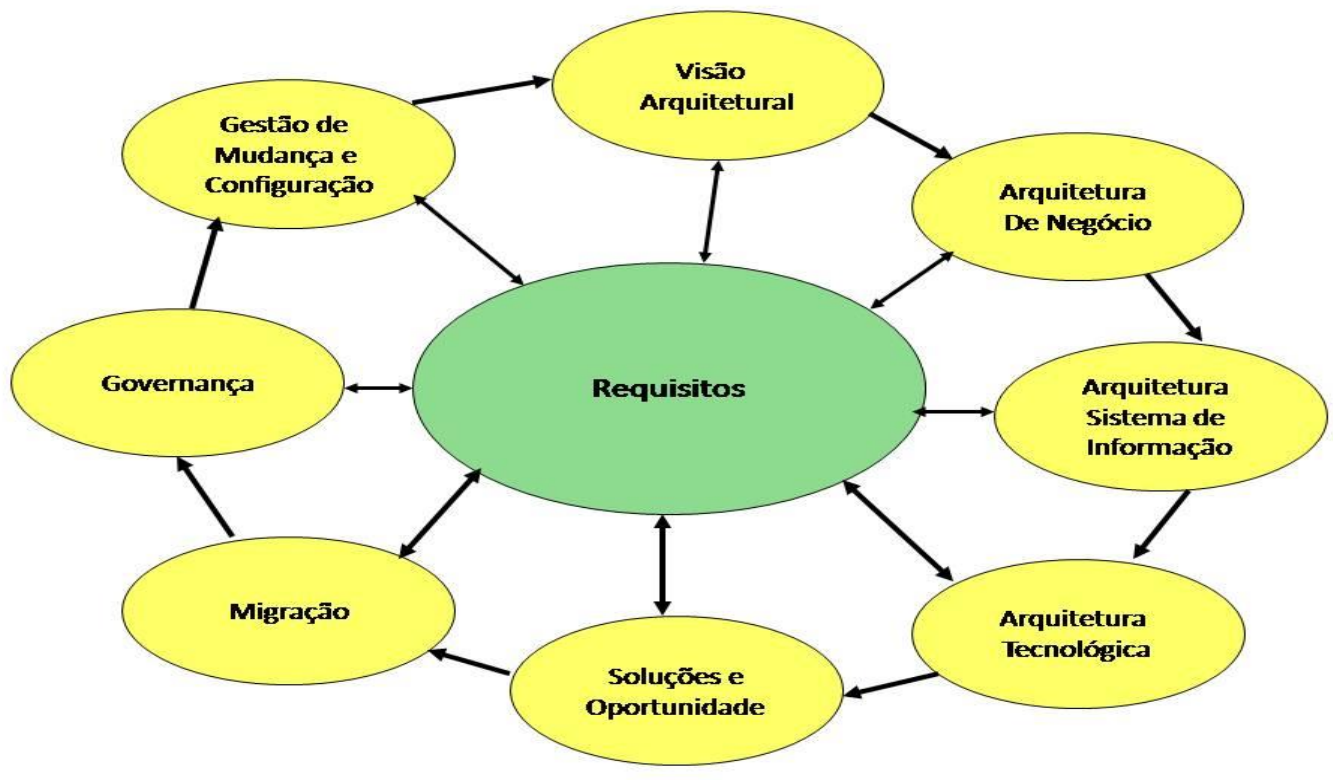

Figura 02 - Abordagem orientada a requisitos

(Ilustração do autor, 2015)

Nessa abordagem os diversos instrumentos de gestão corporativa são transformados em insumos que respondem a determinadas funções estratégicas, onde a meta é o atendimento aos requisitos da organização e onde o processo de negócio também exerce o mesmo papel. Essa estruturação visa tornar todos os processos que subsidiam a organização em suas metas, coadjuvantes para responder cada um por sua vez ou em conjunto aos requisitos e demandas latentes na organização.

Exemplos de aplicação desse modelo sugerido seriam bancos e outras organizações que privilegiam as questões relacionadas com os requisitos de seus sistemas de informação, ou empresas que atuem na área de serviços, pressionadas que são com as questões de qualidade, esse modelo também atenderia a instituições ou setores que tenham como negócio a produção de artefatos de informação, como fábricas de softwares, produção de impressos e outros produtos que tragam como cerne de sua confecção os requisitos de que são dotados.

Outra abordagem também exercida em algumas instituições, sejam estatais ou privadas, focam sua organização e espírito corporativo na centralização das ações na figura da governança corporativa.

Esse modelo atende a setores e empresas que tem numa figura central todo o seu fluxo de controle e de gestão, sendo os demais processos periféricos a essa centralização. A 
figura a seguir ilustra uma estrutura que trata o processo de negócio como parte dessa engrenagem corporativa:

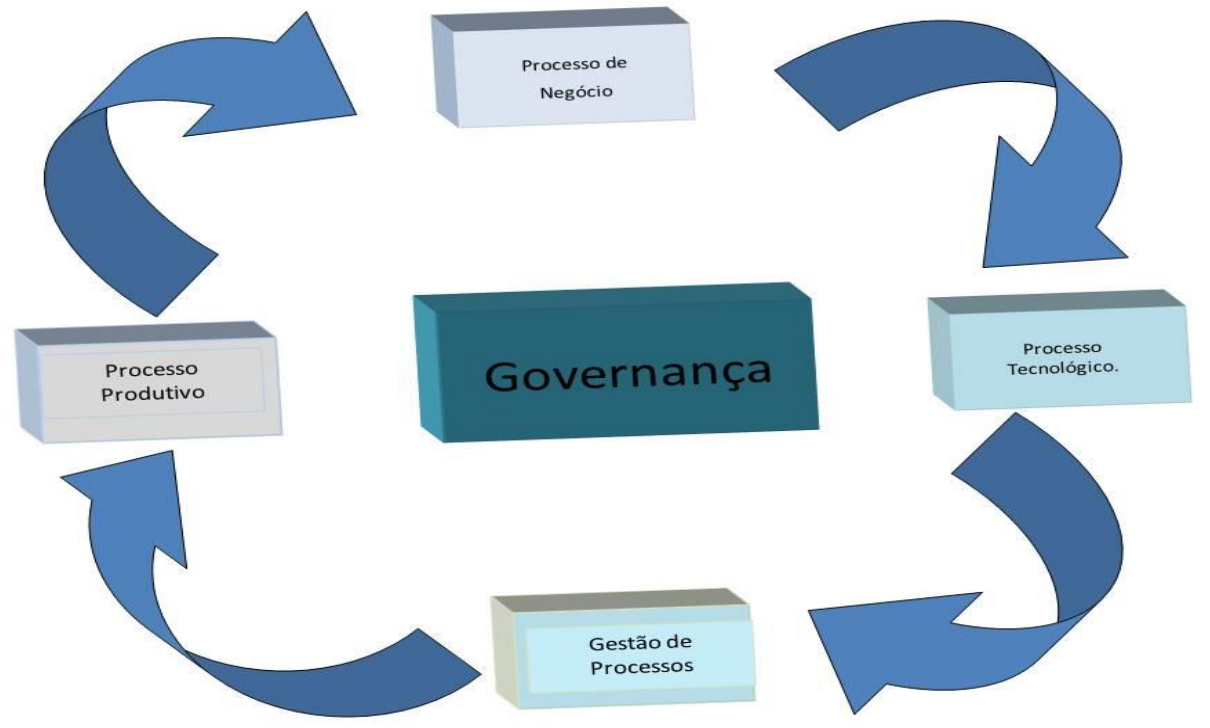

Figura 03 - Arquitetura corporativa centrada na Governança

(Ilustração do autor, 2015)

Nesse caso fica evidente a filosofia centralizadora do modus operandi da organização, mesmo sem entrar no mérito da escolha. Esse modelo também atende bem a tipologia dos serviços terceirizados, onde o papel central é de apenas exercer a governança e toda a engenharia produtiva fica em setores ou atores descentralizados, ou alhures, em terceiros contratados.

Essas ilustrações trazem contribuições para que se perceba a diversidade de enfoques com que o "processo de negócio" é orientado na organização, tanto quanto aos seus modus operandi, quais sejam, metodologias, ferramentas, abordagem interna ou terceirizada, prioridades relativas e outras questões que produzem e interferem nessa diversificação de visões e de maneiras de abordar o tema nas empresas.

Diante da complexidade para se ter o tema trazido à luz sob uma semântica comum, ou pelo menos coerente com os meios atuais de organização e divulgação das informações sobre o tema, essa proposta de pesquisa acode, então, a esse tema, onde é intrínseco um grande número de eventos e de lógicas aparentemente desarticuladas, onde a matéria é focada, práticas afins ou totalmente dissociadas que se encontram no processo de negócio sob as mais diferentes utilidades e abordagens. 


\subsection{Elementos de uma arquitetura orientada por serviços}

No processo evolutivo dessas soluções, cabe registrar, já é possível encontrar-se abordagens e tecnologias que suportam o conceito de "SOA" (Service Oriented Architecture Arquitetura Orientada a Serviços), tornando-se ainda mais sofisticados esses conceitos e critérios, revendo os processos corporativos e funcionais típicos dos antigos sistemas de informação, orientado por funções dos aplicativos, que seguem os modelos informacionais corporativos e se baseia nos organogramas, onde os modelos de informação são estanques e suportados, muitas vezes em soluções tecnológicas monoliticamente construídas para cada setor ou divisão, e estão presente em grande número de organizações, migrando-se essa lógica segregada para a categoria de soluções orientadas a serviço. Essa abordagem necessariamente segue uma lógica corporativa e descarta as antigas visões setoriais.

Essa mudança vem ocorrendo há diversos anos e, malgrados os ganhos que são obtidos na sua adoção, os custos para migrar ou adaptar sistemas, culturas, modelos informacionais, bases de informações, conceitos empresariais, para essa visão tornam ainda embrionária sua efetiva expansão e uso nas organizações.

Essa dificuldade passa também pela questão que encapsula os sistemas de informação aos setores, onde muitos processos são apoiados em diversos deles, costurando-se um conjunto de rotinas para se chegar a uma solução que corresponda a um serviço específico. Essa abordagem segue a orientação dita funcional.

Essa nova visão, processos orientados a serviços, envolve a resolução de fronteiras funcionais, às vezes culturais e mesmo de incompatíveis ambientes operacionais existentes, onde a nova abordagem prevê a superação de todos esses entraves colocando à disposição dos usuários e gestores, processos que se destinam a execução de serviços, devendo os mesmos, assim que implantados, ocultar todo o qualquer procedimento específico vinculado a um determinado sistema de informação.

Para que possa emergir tal abordagem e com ela obter-se a terra prometida do processo das arquiteturas orientadas a serviço, tem-se antes que entender com propriedade os requisitos desse tipo de arquitetura, particularmente as premissas pelas quais ela passa antes de se tornar realidade.

A ilustração a seguir busca demonstrar tal arquitetura, genericamente falando, onde os sistemas baseados em funções deixem de existir - no sentido da interface vista pelos usuários e acima deles é construído/obtido um barramento empresarial de serviços que faz a atividade de integrar todos os processos que sofrem alguma interação com as pessoas, 
"mascarando", por assim dizer, o seu acesso, promovendo-os a um modo de operação background (os sistemas antigos são processados em modo discreto, sem interação direta com os usuários) e, de maneira transparente ao interlocutor humano, o acesso é feito pelos processos automatizados de integração. Esse modelo deixa sem percepção quanto aos sistemas legados, os clientes ou os usuários da empresa.

A ilustração abaixo, busca demonstrar um modelo genérico desse tipo de arquitetura orientada a serviços:

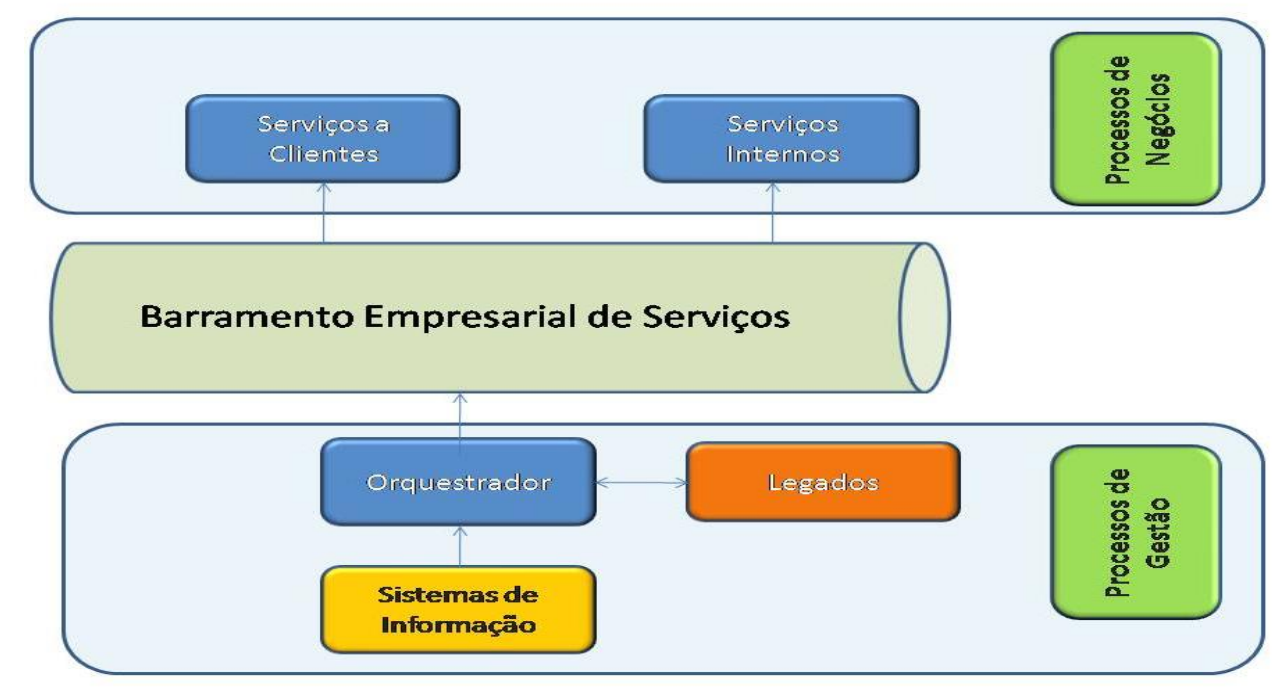

Figura 04 - Arquitetura influenciada pela SOA

(Ilustração do autor, 2015)

Como demonstrado, na Figura 04 acima, a presença da orientação através do barramento empresarial de serviços passa a influenciar fortemente os processos, uma vez que eles passam a ser estabelecidos diretamente frente aos serviços, os quais se tornam a unidade básica de organização dos sistemas de informação, substituindo os antigos processos orientados pelas funcionalidades.

Os sistemas de informação antigos, grande parte ainda em uso, particularmente quando ocupam o conceito de "sistemas críticos", tantas vezes se orientam e são desenvolvidos visando estruturas dos organogramas, ou por soluções construídas em torno dos nichos de atuação nas empresas, de onde emergem aplicativos de informações que ganham vida própria e seguem um sem número de anos, tornando-se o eixo em torno dos quais são criados e extintos setores, estruturas e outras formas de administração, tanto formal quanto informal. 
As vantagens da orientação a serviços abrigam uma série de mudanças, onde os modelos que buscam essa abordagem precisam, conforme de relatos de experiências práticas em empresas que fizeram essa adesão, ter um plano de evolução elaborado com rigor. Os custos são altos. A migração requer grande esforço e tecnologias de ponta. Não se pode, assim, acreditar-se numa popularização muito próxima ou produto de uma ação casual e simples para sua plena implantação.

A ilustração acima apresenta uma estrutura denominada "barramento empresarial de serviços" a qual representa uma hiper-camada de tecnologia da informação (SADIQ \& RACCA, 2003), residindo nela uma série de funções, onde são resolvidas questões como a execução de procedimentos automatizados visando transformar antigos modelos funcionais em modelos orientados a serviços, tais como acessos a sistemas legados, consultas a bases internas ou externas, emulação de uma série de procedimentos automatizados sem que o usuário participe ou interfira neles.

Esse conjunto de funcionalidades busca tornar a existência dos serviços o motor central do processo de negócio, tratando como unidade de conhecimento as regras e as funções inerentes aos serviços e, por assim dizer, camuflando (tecnicamente é dito "colocando em background") os sistemas e suas interações isoladas, que requerem muito mais esforço dos usuários, pois cada sistema tem uma conexão independente (login), as vezes com formatos de senhas e de login diferentes, uma vez que a maioria deles são dos chamados "sistemas legados". Essas interfaces se destinam a obter as unidades de serviços mais simples e mais eficientes.

Para ilustrar essa inovação, tome-se o exemplo de uma rotina de abertura de conta em uma agencia bancária, a qual, pelo modus operandi antigo (orientado e atendido pelos sistemas funcionais) exigiam que os atendentes entrassem em diversos sistemas, fazendo login em cada um deles, interagindo para resolução de funções parciais relacionadas com a abertura de contas e, depois, outro e outro mais, chegando a casa de até dez diferentes sistemas para concluir um processo de abertura de contas.

Com a substituição desse processo pela abordagem de serviços, o acesso aos sistemas fica automatizado a partir de um login único e a visão que o atendente tem é de apenas um serviço, o serviço de abertura de conta. Essa alternativa chega a reduzir mais de $60 \%$ (sessenta por cento) do tempo utilizado para tal tarefa.

Uma fase inicial da implantação dessa tecnologia passa pela adaptação provisória dos modelos existentes, "mascarando" sistemas, interfaces tradicionais, acesso a sistemas 
extranet, internet ou intranet, transparentes e, progressivamente a empresa busca se tornar apta no sentido pleno para a incorporação da filosofia de toda sua atuação orientada a serviços.

Com a evolução desse modelo, as bases de dados, os sistemas de informação e os modelos de processo de negócio, são todos repensados e reescritos, tendo em vista uma nova orientação geral da organização que servirá para mobilizar os fatores críticos dos modelos de negócios, reificando-os para uma nova era de processo de negócio, onde o fator serviço se torne o centro do valor agregado das soluções.

A ilustração apresentada abaixo busca demonstrar essa nova visão que poderá emergir no processo de negócio:

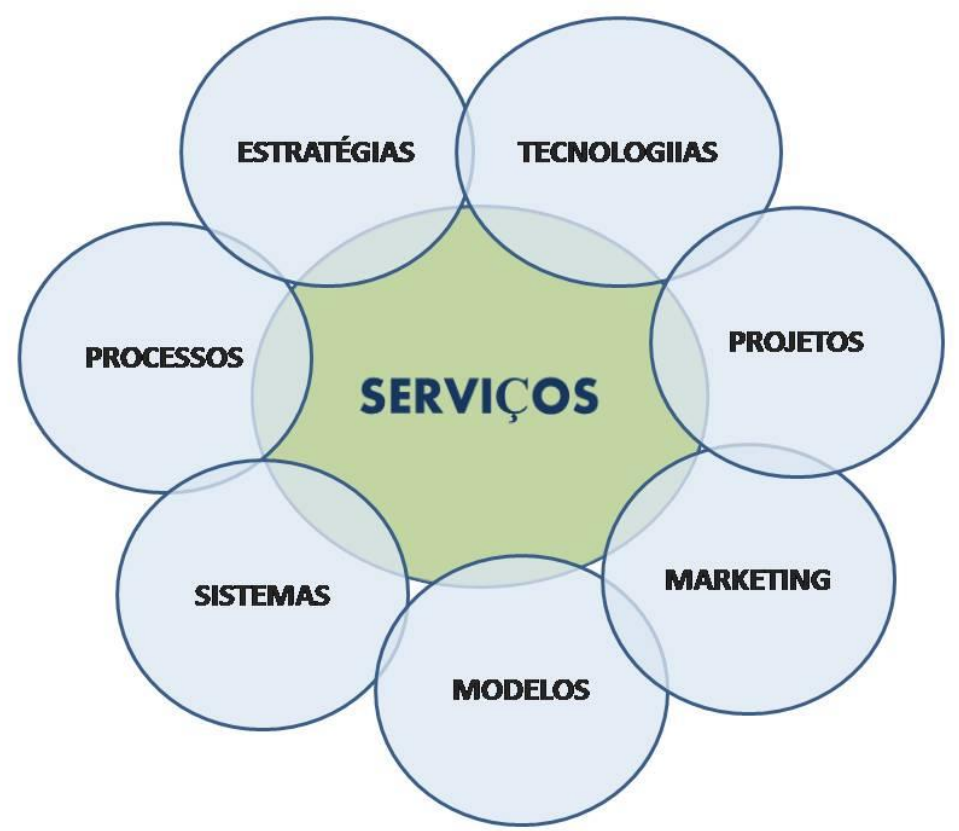

Figura 05 - Organização orientada por serviços

(Ilustração do autor, 2015)

A expectativa é no sentido de que todos os elementos que compõem os modelos de uma organização, deverão migrar no sentido de se tornarem parte de uma estratégia corporativa que tem como diretriz basilar a orientação a serviços. 


\subsection{Elementos Multimodais do processo de negócio}

Dentre os estilos e modus operandi de opções e enfoques para compreender a o processo de negócio, cabe acrescentar, entre elas ainda objetivar essa produção, seja no terreno das atividades dos consultores ou técnicos que atuam no mercado, seja na visão acadêmica, nos casos dos estudos obtidos e arrolados nesta pesquisa, pode-se acrescentar como fator adicional para a compreensão do fenômeno processo de negócio e sua semântica inerente como um estudo de multimodalidade (KRESS et VAN LEEVWEN, 2006).

Essa perspectiva pode ser obtida em se colocando algumas das dimensões em que os estudos sobre esses processos de desenvolvem, entre as quais pode-se identificar as seguintes modalidades de compreensão dos mesmos:

Dimensão Cultural - o processo de negócio é impregnado de questões da personalidade cultural das organizações e isso tanto pode auxiliar como prejudicar a busca da reengenharia desses processos (COSTA, 2001), pois essa dimensão poderia ser utilizada para compreender os fatores de estímulo às equipes, o que se desprezado poderia, ao contrário, tornar-se um elemento de resistência ao trabalho de remodelagem do processo.

Essa visão relativamente simplista da cultura organizacional e sua relação com o processo de negócio se destina a permitir uma visualização desse fator como ponto indissolúvel do problema, acrescentando-lhe esse modo de leitura e abordagem, mormente nos momentos de apresentação dos resultados, na comunicação escrita e outros pontos de contatos diretos com o público interno da organização.

Dimensão Estratégica - o processo de negócio ocupa um importante pilar na forma de cada organização perseguir os seus objetivos e metas de trabalho e de sucesso em sua missão corporativa: o conhecimento sobre isso contribui tanto para a produção de diagnósticos substantivos, quanto para definir os níveis de ajustes que poderiam levá-las ao sucesso ou a melhorias em seus resultados.

Fazem parte do levantamento de qualquer processo institucional, a dimensão estratégica, cuja principal fonte de atuação e de obtenção de resultados está justamente pautado na questão dos referidos processo, sua compreensão ou diagnóstico, sua análise enquanto pontos de estrangulamentos na produção ou no fluxo de informação e decisão, tanto quanto na 
proposição de mudanças, visando novos estágios pretendidos, para o atingimento de metas ou de aderência à visão do negócio pelas organizações.

Dimensão informacional - a análise do processo de negócio passa necessariamente pela compreensão de seus modelos e fluxos de informação. Isso serve tanto para nutrir a compreensão da instituição e seus desígnios estruturais, culturais, operacionais e executivos, como também para permitir diagnósticos dos modos de informação, grau de acuidade, níveis de defasagem, fontes, confiabilidade ou riscos e segurança da informação (HEPP et ROMAN, 2007).

Sobre a ótica informacional é mister destacar-se a confluência de diversos fatores que deverão ser compreendidos para qualquer interferência nos processos de uma instituição, entre esses os sistemas de informação, sejam automatizados ou não (ROBREDO, 2003); as estruturas de metadados e suas bases correspondentes, tanto no aspecto de sua abrangência, como nível de capilaridade das redes, autonomia e integração das informações de setores, equipes, além da própria política de arquiteturas da informação adotadas, pois os principais problemas e limites do processo negocial envolvem suas informações, sua prioridade e características próprias. Segundo Hepp e Roman (2007, pág. 3): “A substantial part of Information Systems literature deals with aspects of modeling business processes", ou seja, não se trata de um fenômeno isolado, é essencial esse enfoque para compreender a dimensão informacional de uma determinada instituição, seja pública ou privada.

Dimensão social - é fato notório que os problemas das organizações passam, em grande parte, pelo grau de integração de seus diferentes níveis e estruturas hierárquicas ou horizontais, tanto quanto ao grau de fluidez das relações interdepartamentais ou setoriais.

Compreender essas relações será de vital importância para o sucesso de uma empreitada transformadora, tanto quanto para a elaboração de um diagnóstico realista que entreveja os impactos do processo de relações humanas nos resultados da empresa (CHAUI, 1986). Há ai uma expectativa implícita de que esse fenômeno humano nas organizações seja o aspecto balizador em si da sua estabilidade.

O conjunto desses fatores combinados entre si ao lado de outros modus, não elencados neste estudo até pela não intenção de uma exploração extenuante dos diversos desdobramentos do tema, servindo antes como proposito ilustrativo dentro do contexto desta dissertação, constituiriam uma contribuição para sua estruturação justamente enquanto tema multimodal para a compreensão e a reengenharia do processo de negócio. 
Para se caracterizar como multimodal é necessária uma conjunção de fatores que forneçam a diversidade de elementos que compõem uma determinada realidade ou contexto. Esse breve insight no contexto deste trabalho pretende apenas emoldurar um conjunto de possibilidades que cercam o objeto de estudos desta pesquisa, permeando-lhe os diversos enfoques que norteiam ou nortearão sua compreensão e sua devida sistematização, tanto como objeto de estudos, como instrumento de atuação tecnológica, na rota dos métodos da engenharia de processos.

\subsection{Elementos da Teoria da Relevância}

Conforme SILVA e DUQUE (2013), a Teoria da Relevância é uma proposta de Sperber \& Wilson (86/95), que visa compreender sobre a racionalidade da comunicação humana e a interface entre o processo comunicativo e cognitivo. Assim sendo estaria presente em qualquer processo humano de comunicação e, ainda, na comunicação homem-máquina (DUQUE, 1998).

Toda a racionalidade por trás de um processo de negócio estaria sujeita, implícita ou explicitamente, às regras de relevância na comunicação e na escolha do modus operandi institucional. Não necessariamente isso careceria de ser visto do ponto de vista econômico financeiro. A racionalidade puramente financeira não poderia ser generalizada como atributo máximo da eficiência ou eficácia de um processo de negócio, em razão de aspectos históricos e culturais, de existência e consequência inerentes a evolução e a sobrevivência de uma instituição de qualquer natureza, devido, inclusive, à sua natureza multimodal, comentada no capítulo anterior.

A escolha do modus operandi por sua vez, implica na economia dos tempos e movimentos de que tratou e ainda trata os profissionais de Organização \& Métodos (FISCHER, 2002). Não se pode afirmar, no entanto, que esse processo de escolhas e de eleição de relevância seja consciente, uma vez que em alguns casos nem mesmo existe, outras vezes não tem a preocupação com a economia do processo em si, como é o caso do lazer e da diversão (SILVA \& DUQUE, 2013).

Porém, no caso do processo de negócio, é justamente onde a busca pela relevância tem uma relação direta com a cognição e a comunicação, já que essa seria a função intrínseca 
de qualquer tipo de interferência nos processos institucionais e, portanto, no processo de negócio.

No caso do processo de negócio, portanto, estaria implícita a presença da escolha da relevância nos modelos de comunicação, tanto institucional e formal, quanto entre as pessoas e também entre os sistemas informatizados e seus usuários.

As funções atribuídas à alta cúpula executiva de uma instituição, são consideradas estratégicas e executivas, implicando essa caracterização como um diferencial da racionalidade das informações que chegam à essas esferas nas organizações.

Decorrente dessa expectativa surgem a alternativa da sintetização das informações, ou sua sumarização, em ambos os casos a seleção de pontos ou os extratos mais relevantes da informação é que deveria chegar a esses gestores.

Assim sendo, aí se encontram aspectos de relevância operando no processo de negócio e, portanto, isso nos interessa, naturalmente, para conhecer a sua ontologia, sua semântica e sua estruturação fundante.

Para a seleção dos termos e dos conceitos que serão adotados para a construção de uma arquitetura de referência do processo de negócio aqui pesquisado, adotar-se-á um critério de relevância, o qual será balizado em entrevista com profissionais da área de processo de negócio, seja na perspectiva tecnológica, seja na sua dimensão empresarial, sob a ótica de consultores de processo de negócio.

Além da entrevista, e a partir dela, pretende-se estender a validação do modelo a um número maior de especialistas, dessa feita via submissão de um formulário de pesquisa via web, utilizando-se o recurso de pesquisa fornecido pelo Google/forms, disponível no acervo de recursos existentes como ferramentas do Google Drive, evidentemente por ser gratuito e de fácil acesso aos profissionais a que se destina.

\subsection{Experiências de campo - observador-participante}

Este pesquisador vivenciou a implantação de soluções de reengenharia de processo de negócio, especificamente projetos tecnológicos de reengenharia organizacional, tendo atuado tanto como Consultor de Processo, como também Especialista de Tecnologia da Informação, obtendo-se daí uma visão abrangente do problema no âmbito de algumas organizações de grande porte, palco de algumas das experiências aqui relatadas, tanto quanto 
experiências envolvendo problemas da mesma natureza em trabalhos como consultor independente no mercado de tecnologia da informação.

Fruto dessas experiências de observador-participante obteve-se um conjunto de arrazoados usuais, onde são produzidos argumentos que se opõem a uma abordagem orientada por processos, dentre esses, algumas propostas surgem naturalmente vindo ao encontro de alguma forma de dificuldade, normalmente encontrada nos projetos que buscam implantar soluções informatizadas de processos ou, antes disso, quando da formatação e argumentação para a chamada "reengenharia de processo", a qual sempre desencadeia alguma resistência declarada ou subliminar, nos atores evolvidos.

Dentre as resistências registradas, algumas delas dirão respeito à disponibilidade de artefatos tecnológicos ou metodológicos que permitam o início de um projeto com essa proposta nas organizações ou instituições de qualquer natureza, ou seja, a existência ou escolha de uma ferramenta ou solução com esse fim.

A opção por uma determinada ferramenta, metodologia ou abordagem, que pode parecer no primeiro momento algo simples, poderá, a depender da complexidade operacional do ambiente da organização, se tornar uma questão crucial e delicada.

A escolha dessa ferramenta passará inicialmente pela existência de diretrizes e políticas das organizações, incluídas no seu plano estratégico, da existência de alguma política que abrigue o investimento correspondente ou alguma tomada de decisão de sua alta gerência que almeje uma mudança em profundidade dos modelos da instituição.

Nessas diretrizes, devem ser obtidas, por exemplo, linhas-mestras quanto aos caminhos que deverão ser percorridos em uma visão empresarial que orientem ações ou aquisições que subsidiem mudanças dessa natureza, tais como:

Níveis de terceirização;

Prioridades setoriais;

Abrangência ou contingência dos investimentos;

Políticas de integração entre setores e sistemas;

Padrões tecnológicos abertos ou outros;

Expectativas de internalização e generalização do domínio sobre os processos;

Papéis e responsabilidades;

Gestores funcionais;

Modelos informacionais (fontes, regras, bases, atributos);

Existência de recursos para investimento; 
Gestores e esponsers com autonomia para autorizar os custos; e

Outras diretrizes pertinentes.

Grande parte dessas diretrizes e políticas virá de requisitos técnicos, os quais serão emanados pela governança de TI ou de gestores de tecnologia da informação nas organizações. Outros tantos deverão vir dos setores de planejamento estratégico, da área de gestão de processos (se houver), ou das áreas de gestão de informações de negócio.

Esses requisitos envolvem questões internas, próprias de cada organização, não devendo ser generalizados e servem, nesta dissertação, apenas para ilustrar a sua tipologia.

Se o processo de adaptação corporativa adotar em sua implantação soluções de automação do processo de negócio, conhecidos como tecnologia workflow ou GED - gestão eletrônica de documentos, alguns outros requisitos de natureza eminentemente técnica, além de critérios decididos em função de padrões operacionais e outras normas internas.

Alguns dos mais comuns parâmetros e critérios que afetam escolhas, no que diga respeito à tecnologia de GED/workflow, são elencados a seguir, para indicar alguns dentre os que provavelmente farão parte deles, a saber:

Suporte a determinados padrões oficiais ou de mercado, a critério dos gestores de tecnologia (a exemplo do WfMC - Workflow Management Coalition ou do BPMn - Business Process Management Notation, entre outros).

$\checkmark$ Definição de ambientes típicos adotados na organização (caso haja uma preferência já existem soluções open-source, ou de fornecedores como a Microsoft, Unix, IBM e outros);

$\checkmark$ A solução deverá ainda se adaptar a critérios que optam por sua aderência a determinados padrões abertos ou evolutivos, conforme diversos deles mencionados nesta relação;

$\checkmark$ Disponibilização de adaptadores que permitam à solução interagir com outras aplicações (e-mail, editores, planilhas, redes sociais);

$\checkmark$ Permitir integração com bases de dados, conforme cada cenário institucional;

$\checkmark$ A ferramenta deverá disponibilizar base de dados que registrem os processos, os atores, os eventos e outros dados e informações, de preferência em tecnologia já do domínio da organização, em função da cultura das equipes e pela facilidade de utilização de ambientes já 
existentes. As opções quase sempre recaem em tecnologia relacional ou outros padrões abertos do mercado, embora grande parte das soluções utilize bases proprietárias e fechadas na aplicação, ainda que suportada em sistemas de gerenciamento do mercado. Isso se dá por questões de integridade, de desempenho e de compatibilidade no caso de existir algum legado de dados, informações ou sistemas da organização já residente na solução adotada;

$\checkmark$ Utilizar padrões que permitam a integração da solução com outras ferramentas de GED, ECM e Imaging;

$\checkmark$ Utilizar padrões abertos de correio eletrônico;

$\checkmark$ Oferecer facilidades de simulação de processos e soluções de BackOffice e prototipação, visando celeridade e aderência a implantação e simulação de novos processos automatizados ou controlado pelo sistema informatizado;

$\checkmark$ Suportar a autenticação de usuários de modo seguro, dinâmico e adequado aos tempos, movimentos e etapas do processo;

$\checkmark$ Oferecer e integrar subprocessos;

$\checkmark$ Dispor de indicadores de desempenho dos processos e atores;

$\checkmark$ Permitir a construção ad hoc de trilhas de auditoria por interfaces amigáveis e resultados compatíveis com atividades e funções gerenciais e de auditoria;

$\checkmark$ Disponibilizar recursos de administração e supervisão com flexibilidade para a definição de direitos individuais, setores ou perfis típicos;

$\checkmark$ Possuir segurança integrada com a tecnologia em uso na empresa (login na rede corporativa servindo para o sistema de processos);

$\checkmark$ Possuir integração com ferramentas de reengenharia de processos;

$\checkmark$ Geração de relatórios com estatísticas de desempenho do processo, das atividades, dos usuários, grupos funcionais e setores das empresas;

Ao lado desses exemplos de critérios e requisitos citados, que ilustram a migração dos processos tradicionais para uma abordagem de processo automatizado numa organização, deverão ainda ser analisados fatores de natureza não tecnológica, o que envolverá questões 
comerciais, recursos logísticos colocados disponíveis, equipes e consultores, enfim, todo o aparato que envolve uma solução confiável e bem suportada, para a empresa interessada.

Consultorias ou outros serviços de parceiros ou terceiros, vinculados à solução orientada a processos deverão também ser escolhidos, especificados e justificados, pela consequência de seus custos e eventuais dificuldades operacionais. 


\section{CAPÍTULO III.}

\section{Metodologia do trabalho}

Esta dissertação tem o caráter de uma pesquisa qualitativo, na medida em que busca a seleção de aspectos e conceitos que definam a essência semântica do fenômeno processo de negócio. Ela também se caracteriza como pesquisa empírica, uma vez que existe um aspecto de pesquisa de campo, estabelecendo diálogo com atores que atuam no terreno profissional e de pesquisa sobre o tema.

A pesquisa se deu, cronologicamente, na forma dos eventos abaixo relatados, que serão explorados e detalhados a seguir, visando a compreensão que melhor permita conhecer os pilares metodológicos, ferramentas e outros insumos que foram importantes para sua conclusão.

$\checkmark$ A pesquisa foi iniciada com a formatação de projeto de pesquisa de mestrado, apresentada no processo de seleção de candidatos para o Mestrado em Ciência da Informação, da Faculdade de Ciência da Informação, da Universidade de Brasília, sendo aceita para a linha de pesquisa em Organização da Informação, especificamente na proposta de Arquitetura da Informação para o processo de negócio;

$\checkmark$ Pesquisa bibliográfica foi desenvolvida, visando subsidiar a compreensão e o suporte teórico temático, tanto quanto metodológico e instrumental;

$\checkmark$ Pesquisa pela internet e outras fontes digitais, pessoais e de parceiros;

$\checkmark$ Mobilização de fontes e acervos pessoais do pesquisador, além do conhecimento e experiências acumuladas como observador-participante;

$\checkmark$ Seleção do material disponível, tanto fontes digitais em computador, da internet e bibliográficos;

$\checkmark$ Participação efetiva em simpósios e interação junto a profissionais da área de interesse da pesquisa, consultores, analistas e gestores em processo de negócio;

$\checkmark$ Releitura de textos de produção própria, com foco no tema;

$\checkmark$ Pesquisa bibliográfica ampla, coletando elementos do "processo de negócio" especificamente para a coletânea de termos e definições do fenômeno; 
$\checkmark$ A seleção dos autores em metodologia e outros aqui citados se deu por serem referência da área pesquisa e no debate epistemológico do tema, de ontologia, semântica e taxonomia.

$\checkmark$ A pesquisa empírica será descrita no capitulo específico sobre a mesma.

Os principais autores que deram suporte ao trabalho, do ponto de vista de sua metodologia foram Eduardo A. Tomanik (2004), João Bosco Medeiros (2011) e José Matias Pereira (2006), havendo subsídios que foram obtidos de estudos publicados que produziram versões de arquiteturas de informação ou ontologias, ou mesmo estudos afins com esses temas, dos quais foram apreendidos também pelos elementos de metodologias que os mesmos adotaram.

A estrutura de formatação, tipos, espaçamento e outros padrões desta dissertação, seguiu as recomendações da Biblioteca Central dos Estudantes da Universidade de Brasília (BCE/UNB), no endereço: http://www.bce.unb.br/normas-bibliograficas/ (último acesso em 26abr2015, às 20,45horas).

A estratégia metodológica adotada nesta dissertação, ao tempo que cumpre o papel sistematizador do trabalho, atende também como meio de facilitar o trabalho, no sentido de oferecer uma trilha que possa recriar seus resultados, e demonstrar as fontes dos critérios quanto às escolhas de abordagens e a seleção de textos que oferecem contribuições ao propósito da pesquisa.

A metodologia utilizada, mais que um artefato normativo, orientou os esforços desta produção, visando representar a síntese de anos de esforços e aprendizados do pesquisador no tema que aqui se materializa (MATIAS-PEREIRA, 2010), bem como as pesquisas específicas que apoiam o conjunto de fundamentos teóricos, referências, premissas e hipóteses.

Entre elas buscou-se uma ferramenta para a representação de uma ontologia dos termos e expressões, organizados segundos os seus atributos e relações. Dentre as opções de ferramentas disponíveis no contexto acadêmico e do mercado, e foram analisadas algumas delas, entre as quais a Treebolic, uma ferramenta disponibilizada pela Sourceforge.net, de razoável simplicidade de utilização; outra opção que permite o desenvolvimento de uma estrutura de conhecimentos em rede, a qual já foi analisada por este autor (COSTA, 2013), servindo plenamente ao fim de representar os elementos de uma ontologia-simples, a qual, de fato, não se destina apenas a oferecer um estudo ontológico no sentido estrito, mas demonstrar algumas relações que existem entre os conceitos e as classes do objeto estudado. 
Também foi realizada entrevista não estruturada com um grupo de especialistas que serviram de apoio para a validação inicial do modelo de ontologia, a qual foi, em seguida, submetida a um grupo maior de profissionais que atuam na área de processo de negócio, cabendo a eles um parecer da ontologia-leve inicialmente proposta.

Para a realização da entrevista com os especialistas, realizou um encontro presencial informal, para a qual foram convidados alguns profissionais de mercado, com os quais se debateu coletivamente, visando a apresentação da proposta da pesquisa e a obtenção de subsídios para a confecção de uma estrutura para a descrição do objeto da pesquisa: o processo de negócio.

Essa entrevista com profissionais forneceu elementos fundamentais para obtenção de approach visando o desenho inicial de uma taxonomia, a qual foi obtida, de modo implícito, junto aos especialistas.

Dessa primeira coletânea passou-se a uma pesquisa via web, para a qual utilizouse a ferramenta de uso livre (sem custo financeiro), oferecida pelo Google, exatamente o Google.drive / formulários de pesquisa.

Foi então construído um questionário web, sendo o mesmo submetido a um grupo de profissionais de reconhecida atuação na área de processo de negócio, através do link da página do formulário de pesquisa. Esse link/formulário foi remetido via e-mail diretamente para pessoas específicas e que trabalham ou pesquisam a respeito do processo de negócio, ou já trabalharam lidando com ele ${ }^{5}$.

Essa opção se encontra disponível como subsídio integrado ao Google/Drive e dentro dele uma opção para a realização de pesquisas diversas, entre as quais foi adaptada a pesquisa desta dissertação. Ambos os artefatos utilizados nesta pesquisa como suporte para a realização da atividade empírica desenvolvida na presente dissertação se encontram disponíveis no Apêndice A e B deste documento.

Após essa fase, o trabalho seguiu no sentido de compor um modelo de arquitetura da informação sobre o processo de negócio, como fenômeno de forma e tipo de organização da informação, no lato senso da expressão.

\footnotetext{
${ }^{5}$ https://docs.google.com/forms/d/1yixx4aEGM69dgEp3OXQ7ze2ez-wg7kl4xkvg6nx3VhM/edit
} 
As experiências profissionais do pesquisador, naturalmente, também interferem com estímulos de uma longa trajetória profissional, os quais foram complementados dos estudos das disciplinas do presente Mestrado (TOMANIK, 2004), juntamente com pesquisas realizadas nas bases de teses e dissertações da Universidade de Brasília, como também em outras bases acadêmicas, tais como a Universidade de São Paulo, Universidade Federal do Paraná, entre outras, obtendo-se nessas bases algumas fontes de estudos que ofereceram contribuições pela analogia temática com essa dissertação, além de ilustrar na compreensão do cenário temático e como parte dos subsídios existentes.

Os estudos e textos aqui apropriados não têm a intenção de esgotar o tema estudado, outros foram estudados por estar mais compreendidos como áreas conexas do objeto de estudos, sendo que deles, em geral, se pode extrair diversos atributos e compreensões que foram utilizados para a construção da arquitetura fundada numa ontologia, ou contribuíram para demonstrar a abrangência com que o tema pode ser tratado no bojo de estudos acadêmicos.

Para esta pesquisa foi desenvolvida uma coleta extensiva de termos, atributos e elementos semânticos do processo de negócio, os quais serão apresentados no final do trabalho, um vocabulário especializado, mas não necessariamente controlado, do jargão do processo de negócio, os quais serão arrolados no capítulo que trata dos resultados obtidos, dentre eles são extraídos os que servirão de elementos e atributos da proposta de um modelo baseado na ontologia do processo de negócio, e daí a construção de uma Arquitetura da Informação ilustrativa desse fenômeno.

As ilações relativas à arquitetura da informação, no curso de todas as etapas do trabalho, também se destinam e foram apropriadas de estudos pesquisados, ora para obter-se uma visão arquitetural dos aspectos importantes do estudo, como também para organizar as informações obtidas no curso da pesquisa, seja tanto em trabalhos empíricos de campo como também estudos de casos e referenciais a respeito do tema.

Como aspectos gerais da metodologia utilizada (MATIAS-PEREIRA, 2010), propõe-se que a pesquisa tem caráter qualitativo, onde se busca demonstrar a viabilidade da construção de uma arquitetura da informação do processo de negócio e, para sua criação, o desenvolvimento de um modelo de ontologia-leve de processo de negócio, a partir de estudos elaborados com o apoio e a notação de uma taxonomia, a qual foi bastante reduzida a no máximo três níveis de organização para estruturação da ontologia-leve de que trata essa dissertação, e essa ontologia, como foi dito, serve para subsidiar a apresentação de uma arquitetura da informação do processo de negócio, pesquisa neste trabalho. 
"No contexto da Ciência da Informação a utilização da ontologia visa diminuir as ambiguidades presentes na linguagem natural através do consenso terminológico" (SANTOS, 2013), essa premissa servirá de base para o encaminhamento do trabalho e a construção da ontologia que se almeja.

Para o trabalho empírico junto aos especialistas, foi realizado, inicialmente, uma entrevista não-estruturada envolvendo 05 (cinco) representantes de diferentes campos de atuação em processo de negócio, havendo entre eles consultores de processos, consultores de inteligência empresarial; analistas de sistemas de workflow e especialistas em sistemas de informação, com experiência em sistemas de automação de processo de negócio.

Esses profissionais apoiaram este pesquisador para produzir a definição dos termos e a estruturação que foi utilizada no questionário que foi, então, submetido a outros diversos especialistas, de modo indireto, por intermédio de uma pesquisa através de questionário via web, conforme registrado no formulário do apêndice A (Questionário Web), do qual, então, é obtida uma avaliação qualitativa da relevância dos termos, classes e subclasses propostas.

Portanto, as atividades empíricas envolveram a seguinte sequência de passos e procedimentos:

$\checkmark$ Realização de reunião de entrevista não-estruturada com um Grupo inicial de experts, para a consolidação de uma taxonomia do processo de negócio e sua apresentação via web para outros participantes em maior número;

$\checkmark$ Após essa reunião, houve a produção de um questionário para uma pesquisa estruturada, visando estabelecer o grau de relevância das classes e subclasses do processo de negócio, a qual foi respondida por um universo bem mais aberto de especialistas, num total de 25 especialistas de diferentes áreas de atuação em processo de negócio;

$\checkmark$ Recepção e consolidação dos resultados obtidos;

$\checkmark$ Analise dos resultados da pesquisa;

$\checkmark$ Confecção de relatórios de análise da pesquisa e seus resultados finais e parciais.

$\checkmark$ Apresentação da conclusão da pesquisa.

$\checkmark$ Registros das considerações finais. 


\subsection{Metodologias de mercado para o processo de negócio}

Uma solução de mercado que se destina ao desenvolvimento de reengenharias do processo de negócio, é a solução oferecida pela RBG - Rummer Bräscher e Geary, a qual foi criada na década de 90 pelos consultores que dão seus nomes, as letras iniciais, que compõe a denominação da empresa/método de trabalho. São eles Alan P. Bräscher, Geary A. e Rummler, com o objetivo de melhorar radicalmente o desempenho da organização, a partir da redefinição de seus processos interfuncionais críticos, visando melhorar o desempenho da organização (MACHADO et FISCHER, 2002).

Essa metodologia tornou-se bastante conhecida no mercado, tendo sido utilizada - e ainda o é - por empresas de diversas naturezas, tanto quanto uma grande diversidade de tipologias de problemas que sofrem sua análise e reengenharia através do seu método de trabalho.

Para sistematizar sua atuação, os consultores que adotam essa metodologia definem os tipos de processos no modelo a seguir:

Tabela I - Tipos de Processos Segundo a Rummler Bräscher Group

\begin{tabular}{|l|l|}
\hline TIPO DE PROCESSO & \multicolumn{1}{c|}{ EXEMPLOS DE PROCESSOS } \\
\hline $\begin{array}{l}\text { Processos } \\
\text { Gerenciais }\end{array}$ & $\begin{array}{l}\text { Formular estratégia; estabelecer metas de fornecimento } \\
\text { do produto; planejar para fornecer o produto; projetar a organização } \\
\text { para fornecer o produto; gerenciar o fornecimento do produto. }\end{array}$ \\
\hline $\begin{array}{l}\text { Processos } \\
\text { Auxiliares }\end{array}$ & $\begin{array}{l}\text { Comprar/alocar/gerenciar os recursos para fornecimento } \\
\text { do produto; fornecer informações para gerenciar o fornecimento de } \\
\text { produtos; atender as exigências governamentais. }\end{array}$ \\
\hline $\begin{array}{l}\text { Processos } \\
\text { Primários }\end{array}$ & $\begin{array}{l}\text { Vender o produto; produzir e entregar o produto; Dar } \\
\text { assistência técnica ao produto; desenvolver e aperfeiçoar o produto; } \\
\text { tirar o produto de linha. }\end{array}$ \\
\hline
\end{tabular}

Fonte: Manual do Consultor Fundação Dom Cabral, 1999

(Apud MACHADO et FISCHER, 2002)

Essa metodologia propõe a construção de diagramas de estudos onde são organizados atores que integrem a rede do processo, as funcionalidades que ocorrem neles, numa linha de precedência, criando uma visualização que oferece, em um único mapa, as informações que compõem as decisões tomadas no processo que está sendo estudado, no qual se está procedendo a uma reengenharia. 
Segue exemplo do referido diagrama, denominado na RGB como mapa de processos (MACHADO et FISCHER, 2002):

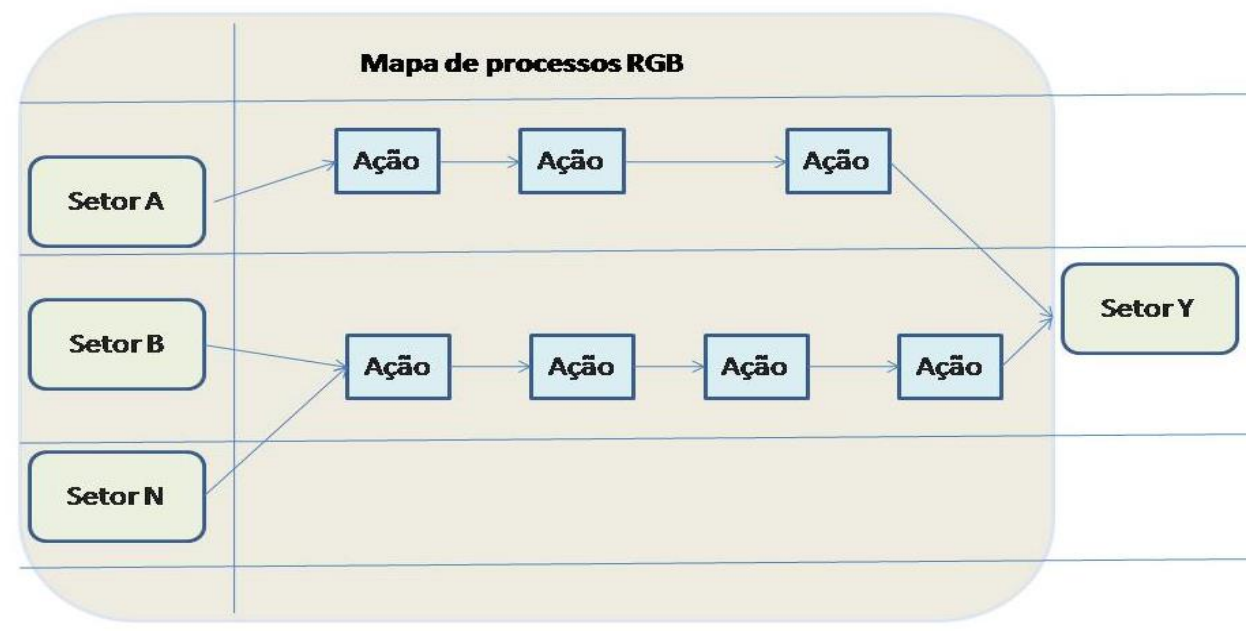

Figura 06 - Mapa de processos RGB

Fonte: versão do autor, 2105, inspirado em MACHADO et FISCHER, 2002

O mapa organiza os componentes do processo, setores e ações/funções, e sistematiza os fluxos de informação corporativa como são para depois proporem o como será, seguindo raias de fluxos de processos e oferecendo uma visualização de fácil compreensão e interação dos envolvidos. Que definem da seguinte forma a forma e a utilidade do referido diagrama:

(...) identificar: os dados utilizados na construção das informações e do conhecimento; de que forma os dados são coletados (se por homens ou máquinas, processos manuais ou sistêmicos); se os dados devem ser excluídos dos processos de negócios da organização por apresentarem problemas (ambiguidade, inutilidade, duplicidade, etc.); se os processos que manipulam os dados são operacionais, táticos ou estratégicos e, por fim, se o foco, a abrangência e os limites da aplicação da norma estão adequados e sobre quais processos ela estará sendo aplicada.

(MACHADO E FISCHER, 2002, pag. 5)

Além desse método aqui apresentado, existe uma infinidade de soluções no mercado que se propõem a resolver questões de engenharia e reengenharia de processos em empresas das mais diversas naturezas de atuação, porte ou tipo.

Para cada caso, cada empresa, poderá ser detectada questões e necessidades próprias, o que irá requerer critérios e opções pontuais, dificilmente, podendo as mesmas serem antecipadas por quem esteja longe da realidade de cada corporação. 
A área de gestão de TI da instituição, responsável pela validação ou avaliação dos impactos - estudo de viabilidade de um projeto para a internalização da gestão de processos deverá avaliar também os recursos logísticos disponíveis, confrontando-os com as diretrizes e expectativas da alta administração.

O pressuposto para todo o aparato que será deslocado para adequar-se a uma solução orientada aos processos, passa por uma decisão corporativa e, uma vez emanada, tal decisão deverá abrir o caminho que viabilizará todo o processo de mudança, todos os meios para a sua efetividade.

A fragilidade do processo de negócio enquanto fenômeno, ou como uma abordagem de pesquisa, o torna, no entendimento e na percepção do conjunto das publicações obtidas, e nas conclusões a priori deste pesquisador, um fenômeno transparente, onde ele é visto como algo inerente ao fluxo da informação, mas até então não atraiu o interesse enquanto foco de atenção, sendo exatamente este o objetivo deste estudo.

A adoção do uso de modelos de arquitetura da informação neste estudo, se justifica a partir do que se tornou uma das mais atuais e importantes abordagens para a efetiva aplicação dos elementos da Ciência da Informação, através da formatação de modelos de organização da informação no contexto de seus espaços informacionais, já tendo se tornado uma nova profissão no mercado da tecnologia da informação, embora não necessariamente na mesma orientação que é vista e proposta no estrito senso da CI.

As arquiteturas de informação vem respondendo por questões muito abrangentes e diversificadas, trazendo nisso e por isso novos desafios para os pesquisadores e estudiosos no universo das demandas e lidas com grandes ou diversificados volumes de informação, em que são levantadas necessidades tanto do poder público, da sociedade e das organizações, quanto das demais áreas de pesquisas acadêmicas, haja visto que enquanto arquitetura a noção serve desde que se trate de espaços de informação, sua sistematização, seus fluxos, suas interfaces e com elas toda a noção de amigabilidade, e ergonomia, qualidades e estruturação semântica, ontologias ou taxonomias, sendo essas ultimas fortemente utilizadas para a construção das ontologias.

Esta pesquisa traz a premissa de que o processo de negócio seja um desses segmentos de demanda e problema, uma vez que existe latente no discurso e nos diversos circuitos de mercado e mesmo em estudos acadêmicos arrolados como subsídios e referências deste trabalho, a recorrente adoção de arquiteturas como meio de sistematizar e organizar 
informações e representações simbólicas dos nichos analisados. Isso reforça o interesse desta pesquisa, enquanto expressão arquitetural.

Visando responder as suas demandas e focos de interesse, a academia busca o aperfeiçoamento de seus próprios meios de trabalho, artefatos para o desenvolvimento de projetos de pesquisa e de soluções que atendam às normas e padrões dos próprios processos de pesquisa, seja na área da Ciência da Informação, tanto quanto de outras linhas e áreas de pesquisa, onde a noção de AI possa servir também.

De fato, a CI se situa no limiar de outros setores da universidade, sendo algumas vezes subsídios para eles, por sua condição de supridora de regras e artefatos de classificação da informação latu sensu é, assim, uma área científica tipicamente interdisciplinar, a qual atua como um provedor de soluções para as demais ciências, no que diz respeito à informação, ou seja, prover pesquisa, aplicações e serviços (ROBREDO, 2003).

Em diversos segmentos da indústria do software, mormente é aplicada essa abordagem à modelagem ou a reengenharia do processo, destaca-se ainda a metodologia genericamente denominada BPM - Business Process Manager que, além de outras variantes dessa designação, promovem e torna-se a cada dia um padrão de mercado - e também em diversos estudos acadêmicos, aplicada essa abordagem em tecnologias consagradas, como workflow, ECM - Enterprise Content Manager, SOA - Service Oriented Architecture e muitas outras definições, todas elas tendo como objeto de trabalho o mesmo objeto: o processo de negócios.

Nos estudos obtidos nesta pesquisa de dissertação, encontrou-se inúmeras formas de utilização do conceito de processo de negócio, quanto à gerencia desses processos, justamente por conta de toda uma demanda que paira sobre a necessidade de se conter e controlar os referidos fluxos informacionais, não tendo sido obtidos estudos em que os conceitos de processo, em sua ontologia e significados semânticos.

Hepp \& Roman (2007, pág. 02), fazem a seguinte reflexão: 
Assim é também presumível a ausência de estudos focando a ontologia desse conceito, sua natureza semântica ou sua origem conceitual.

\subsection{Métodos e ferramentas para representação de modelos arquiteturais}

As opções existentes para representar-se arquiteturas da informação e outras representações de modelos gráficos, são inúmeros.

Para esta pesquisa, adotou-se as alternativas a seguir descritas:

$\checkmark$ Para os modelos gráficos, utilizou-se desenhos livros, representando as classes inicialmente identificadas para a arquitetura proposta;

$\checkmark$ Para a representação navegável do modelo, descrito na figura 10 desta dissertação, foi utilizada a ferramenta de desenho de árvore hiperbólica Treebolic, já mencionada, a qual serviu à representação da árvore de conhecimento completa, descrita na conclusão desta dissertação a qual, em virtude desta versão impressa não permitir a visualização de suas características navegacionais, será aqui registrada apenas através de uma imagem que representa um flagrante da tela navegável. Caso haja interesse na versão navegável, basta entrar em contato com o autor.

$\checkmark$ Para representação da arquitetura da informação descrita na figura 09, utilizou-se os conceitos da SSM - Soft System Methodology (CHECKLAND e POULTER, 2000). 


\section{CAPITULO IV.}

\section{Resultados da Pesquisa}

Nos itens abaixo, serão apresentados os resultados obtidos durante o processo de exploração das possibilidades empírica envolvendo o conceito, os aspectos semânticos e, principalmente, a obtenção e a produção de uma estrutura ontológica e, dela, a obtenção de visões arquiteturas pretendidas nesta pesquisa.

\subsection{Pesquisa empírica - descrição e relatos}

A pesquisa empírica se iniciou na entrevista não estruturada com especialistas e, nessa fase, utilizou-se uma primeira coletânea de termos e taxonomias, obtidas dos textos pesquisados e da inferência do pesquisador, que buscava a formulação inicial de um modelo semântico para o processo de negócio.

Essa coletânea serviu de motivação para a entrevista não estruturada com os especialistas, mencionada na metodologia desta pesquisa.

O questionário inicial que foi debatido com especialistas se encontra representado na imagem a seguir: 


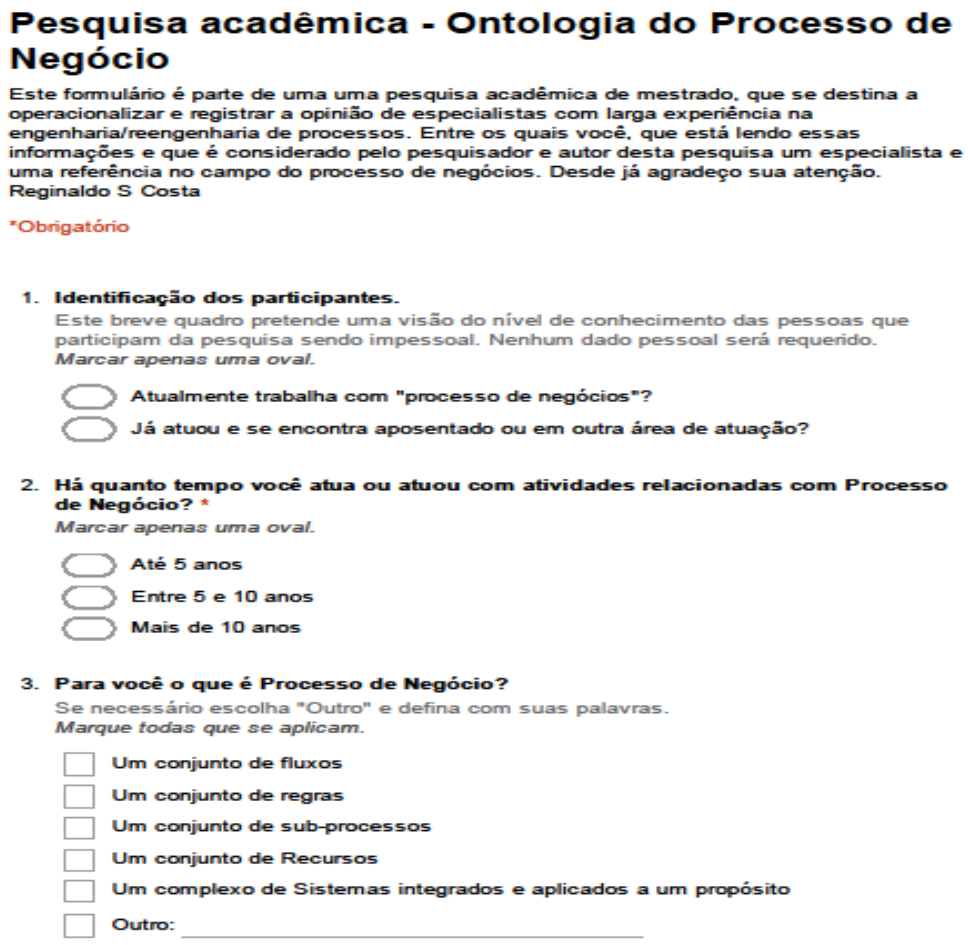

Ressalte-se que esse questionário foi utilizado apenas como motivador para o debate com os especialistas, pois ele apenas trazia uma vaga ideia do que queria-se buscar.

O que foi discutido, portanto, tratou de uma visão anterior ao próprio questionário, nesse momento representada pela estruturação do problema, a noção do modo como se poderia abordar a discussão. Foi dessa entrevista que surgiu, então, a proposta de se adotar uma gradação em termos de relevância, e também a divisão do fenômeno entre classes e subclasses.

Essa alternativa passou então a ser a forma de abordar o problema, o que foi materializado na estrutura do questionário definitivo, consignado nesta pesquisa sob o índice de Apêndice A.

Passou-se então, a fase da pesquisa via web.

Para a eleição dos participantes e convidados para responder a referida pesquisa, utilizou-se, inicialmente, da rede de contatos do pesquisador, há anos atuando no mercado de tecnologias voltadas para o processo de negócio. 
Dessa rede, foram obtidos cerca de 40 (quarenta) contatos, através de redes sociais e de listas de e-mail, aos quais, então, foi dirigida uma mensagem pessoal do pesquisador, solicitando a participação do referido especialista na pesquisa, através da resposta ao questionário, o qual foi apresentado através de link via web, que dava acesso à página do questionário, dessa feita através do Google.com/forms. O questionário esteve acessível durante 8 (oito) dias.

Depois de encerrada a participação, o sistema deixou de receber contribuições.

Para manter os participantes informados sobre o resultado da pesquisa, especificamente a parte da participação via web, foi disponibilizado aos mesmos, destinatários do convite inicial, um link que mostrava os gráficos dos resultados da enquete, através de mensagem eletrônica e o link para os resultados gráficos da pesquisa.

Cumprida essa fase de campo, passou-se à análise e a interpretação dos resultados da pesquisa, além de, principalmente, a obtenção dos modelos de arquiteturas que são apresentados nas páginas que se acham registrados nos itens seguintes deste Capitulo IV, e seus subitens.

\subsubsection{A descrição de um objeto multidimensional e multifacetado}

No decorrer da execução desta pesquisa, pode-se perceber a natureza tanto multidisciplinar, como multidimensional da essência do fenômeno denominado processo de negócio.

Sua faceta semântica é fugaz, no sentido de desviar-se sempre na direção do próximo enfoque em que o mesmo é encampado ou percebido. Em um movimento de descoberta e redescoberta constante e dinâmica, envolvendo autores e diversas orientações e interesses, tanto quanto os atores que reinterpretam o seu conceito e sua aplicação. Portanto, torna-se um processo de grande abrangência.

Essa breve introdução permite vislumbrar que o objeto desta pesquisa, o processo de negócio, na verdade encontra-se sempre ajustado em concordância a muitas e diferentes possibilidades de sua leitura, assim como, adequado à aplicação no contexto das mais variadas experiências, tanto acadêmicas quanto tecnológica e mesmo negociais.

Algumas das facetas identificadas na busca da definição e identificação do processo de negócio enquanto objeto de pesquisa, buscando sua tradução semântica, 
transparece a dificuldade quando se busca uma forma de sua conceituação unitária, universal e, portanto, ontológica.

Para ilustração da abrangência mencionada, segue-se algumas das identidades obtidas nesta pesquisa e, com elas, uma pequena descrição de suas peculiaridades em cada contexto:

$\checkmark$ Enquanto tema de interesse de pesquisadores acadêmicos, foram selecionados diversos trabalhos que foram lidos e apropriados como referências bibliográficas, tanto quanto citadas e debatidas no decorrer do estudo aqui apresentado;

$\checkmark$ Como área de interesse acadêmico, destaca-se abaixo alguns deles, também apropriados e debatidos no curso desta pesquisa:

1. “Contribuições para Melhoria da Gestão Organizacional por Intermédio de Processo de negócio", Dissertação de Mestrado (fls. 26);

2. $4^{\mathrm{o}}$ Intercambio de Processos Organizacionais, evento realizado no âmbito da FCI/CPAI, que visa o diálogo entre a academia e as instituições públicas, visando o intercâmbio de produções e problemáticas que permeiam os atores desse debate (pág. 15); e outros.

$\checkmark$ Sendo instrumento de agregação de profissionais do mercado, que se articulam visando sistematizar questões e padrões que afetam a tecnologia e os serviços relacionados com o processo de negócio, também compartilharem estudos e experiências vencedoras no trato com o processo de negócio, gerando a dinâmica denominada melhores práticas, sob esse manto de visões, vamos encontrar a autodenominada ABPMP - Association of Business Process Management Professional, a qual movimento além de um volume grande de produção de novos conhecimentos, também um razoável volume de novas propostas e insights para a lida com a questão deste objeto, o processo de negócio;

$\checkmark$ Existe a tecnologia denominada workflow, que desenvolve a automação dos fluxos de trabalhos dos processos em empresas de todas as naturezas, também são olhares dos quais derivam constantemente 
novas tecnologias e artefatos que suportam e interferem nas relações entre usuários e solução corporativas de gestão do processo de negócio; Há sistemas de informação e suas regras de negócio, tantas vezes embutem em si, de modo explícito ou implícito, regras do processo de negócio, o qual, nesse contexto se torna parte de uma nebulosa engrenagem onde atores, trabalhadores de empresas públicas ou privadas, se submetem ao julgo desse controle e são apenas operários de informações de todos os tipos, desde estratégicas até operacionais e de simples manuseio de recursos informacionais. Entre outros casos e redutos que tratam desse tema fascinante.

Para representar um universo de conhecimentos, terminologias e abrangência, haveria necessidade de muito mais esforço, tanto individual quanto no coletivo dos especialistas do front de processo de negócio.

Portanto, para clarificar a intenção deste pesquisador, o propósito deste trabalho representará uma síntese desse fenômeno tão intrigante e de interesse de tantos diferentes setores da vida social, acadêmica e produtiva.

Para representá-lo, então, é que se adote uma "arquitetura da informação", a qual busca assim desvelar o sentido abrangente do fenômeno informacional, por trás desse universo de profusão produtiva e dos conhecimentos ali residentes.

Tal arquitetura, fatalmente, carece do approach dos elementos fundantes do objeto e de suas ilações e relações, sejam elas taxonômicas ou funcionais. Caso se deseje a representação e assim se alcançar, será uma forma de se afirmar tratar-se da organização das informações que a compõem, no espectro de razoável abrangência.

\subsubsection{Representação de uma estrutura Ontológica}

Para descrever o resultado da pesquisa aqui desenvolvida e relatada, escolheu-se alguns artefatos consagrados no universo da academia, particularmente dentre opções já consideradas como aceitáveis estruturas para representação do conhecimento relativo ao tema estudado, o processo de negócio, como descrito na metodologia apresentada nesta dissertação.

Assim, para suprir a necessidade de obtenção de opinamento e validação da terminologia proposta, adotou-se um questionário interativo, no formato da ilustração abaixo, 
onde esse método permitiu uma gradação da relevância do item, na opinião do especialista, estabelecendo-se assim uma classificação do mesmo, tanto quanto, implicitamente, quanto ao seu grau de importância ou, pelo menos, a existência ou não de uma deliberada irrelevância do que mesmo representasse.

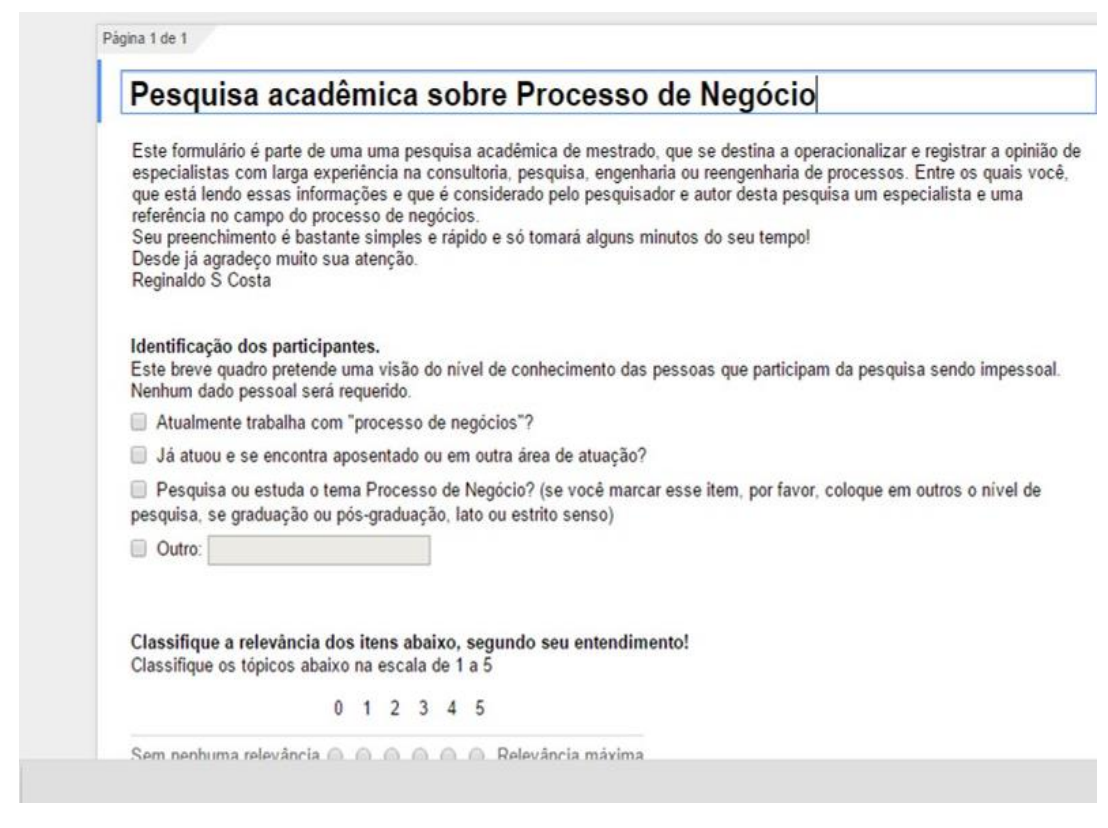

Figura 07 - Imagem do Formulário de avaliação terminológica Fonte: criação do autor, 2015

Esse formulário foi divulgado entre especialistas e esses interagiram com o mesmo, emprestando sua opinião, visando graduar a relevância do item sugerido/proposto.

\subsubsection{Taxonomia Navegacional}

A adoção de uma taxonomia como forma de alimentar um modelo ontológico, é uma das alternativas já consagradas visando a construção desses artefatos, desde que o modelo de conhecimento existente no objeto seja compatível com as premissas da taxonomia.

Pelas razões a seguir elencadas, justificou-se a adoção feita para a construção do modelo de organização da informação do processo de negócio, na forma de taxonomia, dentre as opções que foram estudadas para a construção de uma ontologia ilustrativa do fenômeno do processo de negócio. 
Embora o objeto de estudos seja, como dito, as vezes volátil e adaptável a diversas linguagens, a escolha da taxonomia navegacional se justificou-se pelas seguintes premissas:

a) Compatibilidade;

b) Estimulação;

c) Comunicabilidade;

d) Utilidade.

Essa classificação vem ao encontro das características e propriedades do fenômeno estudado nesta dissertação, conforme recomenda o estudo desenvolvido por Cavalcante (2012, págs. 42/43).

Essa natureza de problema, permitiu algumas possibilidades para sua modelagem enquanto uma estrutura taxonômica. Portanto, para o objetivo desta dissertação, o simples fato de permitir a navegabilidade do conceito, seja por seus conhecedores, especialistas de diversas áreas, tanto quanto por usuários ou estudiosos que pretendam conhecer o alcance de suas nuances e extensão, a navegabilidade foi suficiente para a compreensão de seus desígnios estruturais.

Assim sendo, segue uma análise que permite melhor compreender a justificativa da adesão do objeto desta pesquisa às linhas definidoras de uma taxonomia navegacional:

a) Compatibilidade: A estrutura dominante que busca a representação do processo de negócio é, predominantemente, apresentado sob a perspectiva de sua orientação em rede, onde sua interface recai quase sempre no sentido de uma visualização sob a forma de fluxos, havendo alguns modelos que são mais estanques, denominados modelos ad hoc, visões específicas e únicas obtidas dos modelos de rede; em outros casos podem conter estruturas compatíveis com as atividades e funções da organização em sua estrutura organizacional ou fluxo de decisão, em todos esses exemplos, o processo de negócio, enquanto taxonomia navegacional oferece compatibilidade e, enquanto rede ou estrutura de sucessivos passos, adequando-se com a noção de navegabilidade;

b) Estimulação: Essa qualidade pressupõe que a taxonomia produza um efeito de facilitar a comunicação e a compreensão natural com os usuários do segmento que a taxonomia aborda.

c) Comunicabilidade: Os termos devem ser representativos dos conceitos por detrás da taxonomia, ela adere inclusive à linguagem típica dos usuários que 
com ela lidam, essa premissa, antes de mais nada, é critério para a própria escolha dos termos a empregar;

d) Utilidade: A taxonomia deverá ser composta por termos essenciais para a compreensão da proposta representada. Sendo ainda, se necessário, subdivididos para sua maior abrangência, quando for o caso.

Assim sendo, a conclusão e o entendimento desta pesquisa foram no sentido de que uma taxonomia navegacional, traz suficientes elementos para a compreensão dessa terminologia representativa da organização da informação relativa ao processo de negócio. Sendo assim, portanto, compatível com as especificidades desse tema/objeto.

Segue, abaixo, um quadro demonstrativo da organização da taxonomia que se consolidou no curso desta pesquisa e com a qual será representado os pilares da ontologia do processo de negócio: 


\begin{tabular}{|c|c|c|}
\hline \multicolumn{3}{|c|}{ Taxonomia do processo de negócio } \\
\hline \multirow{3}{*}{$\begin{array}{l}\text { Processo de } \\
\text { Negócio }\end{array}$} & Conhecimento & $\begin{array}{l}\text { Regras/Normas } \\
\text { Organograma } \\
\text { Mapeamento } \\
\text { Documentos e formulários } \\
\text { Aplicativos } \\
\text { Cultura empresarial } \\
\text { Clima organizacional } \\
\text { Estrutura hierárquica } \\
\text { Know-how } \\
\text { Imagem }\end{array}$ \\
\hline & Interferência & $\begin{array}{l}\text { Fluxo de trabalho } \\
\text { Regras e papéis } \\
\text { Workflow e GED } \\
\text { Reciclagem Pessoas } \\
\text { Estrutura organizacional e as funções }\end{array}$ \\
\hline & Avaliação & $\begin{array}{l}\text { Indicadores dos processos } \\
\text { Satisfação dos clientes } \\
\text { Desempenho de colaboradores } \\
\text { Controladoria e Governança } \\
\text { Sistemas automatizados }\end{array}$ \\
\hline
\end{tabular}

Esses foram os elementos pesquisados e utilizados na estruturação do questionário submetido aos especialistas, onde eles deram sua opinião sobre a relevância de cada uma dessas classes e subclasses do processo de negócio. 


\subsubsection{Questionário web}

Em reunião informal e não estruturada com alguns especialistas que atuam em diferentes áreas do processo de negócio, registrou-se diversos insights relativas ao modus operandi desses profissionais. A mais relevante conclusão foi da já mencionada dispersão do conceito, uma vez que a diversidade de formas de sua utilização, tanto quanto o porte, cultura, níveis econômicos e natureza do processo de negócio encontrado e a própria tangência dos perfis envolvidos em tal universo, tornaria impraticável, no contexto de uma dissertação desta natureza, a apreensão de opiniões de todos esses atores.

No entanto, houve consenso no sentido de que um modelo de pesquisa aberta via web, poderia trazer contribuições para a classificação do grau de relevância desses conceitos e sua avaliação por especialistas que atuam diretamente como profissionais de processo de negócio. Tal pesquisa daria balizamento a proposta da ontologia a ser empregada e, portanto, sustentação à arquitetura da informação proposta.

Desta forma foi detalhado e cabe aqui reforçar, o caráter didático do modelo, ressalvado o fato de não ter o mesmo a pretensão de esgotar o fenômeno em toda sua extensão, o trabalho serviu, antes, para subsidiar estudos sobre aspectos ontológicos do processo de negócio.

Além desse aspecto, cumpre destacar que a opinião dos especialistas trouxe também importante contribuição no sentido da consagração da terminologia e da taxonomia utilizada. Não houve nenhuma das classes definidas foi descartada do ponto de vista de sua relevância, contudo, em algumas a importância foi considerada relativamente baixa.

Sendo assim, haveria o pressuposto da possibilidade de alguma das propostas ser totalmente desprezada e, no entanto, o pior grau de relevância foi de um único especialista, para a proposta do conhecimento através do "mapeamento de processos" (técnica de abordagem comumente utilizada pelos profissionais de Consultoria de processo de negócio, através de ferramentas e métodos como a metodologia RBG citada nesta pesquisa).

Essa resposta praticamente fugiu à linha média, mediana ou normal da pesquisa, que se achou bastante distante dos demais $96 \%$ (noventa e seis por cento) dos que responderam à pesquisa e que atribuíram alguma relevância aos itens propostos.

Destaca-se que a seleção dos participantes se deu por convite direto, seja pelo pesquisador/autor, ou através dos convidados inicialmente, estabelecendo-se, assim, uma rede 
de conexão entre profissionais do ramo do processo de negócio. Praticamente excluiu-se a possibilidade de algum participante não se adequar ao perfil esperado.

Embora há que se admitir essa possibilidade, por mais remota que seja, uma vez que não havia identificação das pessoas que responderam ao questionário, que era anônimo e poderia ser utilizado por alguém que tivesse acesso ao link.

\subsection{Resumos da Pesquisa}

A pesquisa foi respondida por 25 (vinte e cinco) pessoas, distribuídos no seguinte perfil:

\section{Perfil dos Participantes \\ (números totais)}

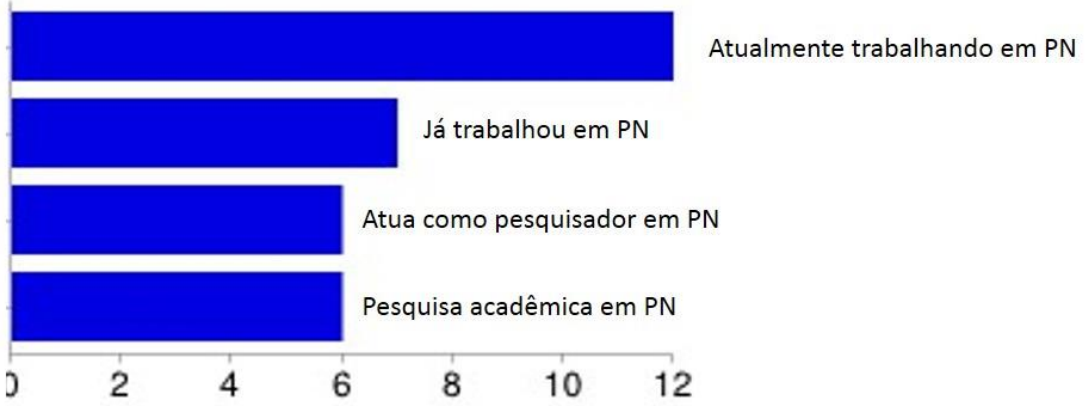

Fonte: Questionário web (criação do autor, 2015)

Como dito, o perfil dos participantes foi bastante homogêneo, no sentido de algum conhecimento prévio do tema pesquisado. Em geral apoiaram a relevância das propostas, enquanto representativas de um opinamento balizado e balizador da ontologia sobre o tema.

Admitiu-se a controvérsia inerente aos processos intelectuais da pesquisa acadêmica. Mormente quando se convive com o universo empírico das práticas de mercado ou do front da tecnologia da informação, dada a sua expansão e diversidade de vertentes que emergem a cada momento, a partir de um nicho de conhecimento, de demandas e/ou de mercado. 
O resultado das respostas ofereceu uma razoável hegemonia, embora alguns itens tenham sido mais fragmentados que outros, como se poderá apreender dos gráficos das respostas que se seguem e que serão comentadas e analisadas a seguir:

Todas as questões foram submetidas a uma avaliação escalar de sua relevância, segundo o ponto de vista do participante da pesquisa. Esse modelo foi oferecido para ilustrar a inteiração e, principalmente, para tornar o processo de respostas simples e objetivo, além de uma interface que demandasse o mínimo de tempo e esforço do pesquisado.

\begin{tabular}{|c|c|c|c|c|c|c|}
\hline \multicolumn{7}{|c|}{$\begin{array}{l}\text { Classifique a relevância dos itens abaixo, segundo seu entendimento } \\
\text { Classifique os tópicos abaixo na escala de } 1 \text { a } 5\end{array}$} \\
\hline 0 & 1 & 2 & 3 & 4 & 5 & \\
\hline Sem nenhuma relevância $C$ & $C$ & $\mathrm{C}$ & $C$ & $C$ & 0 & Relevância máxima \\
\hline
\end{tabular}

A organização do questionário, obedeceu à estrutura da taxonomia inicialmente desenhada, visando a sua fácil assimilação pelo pesquisado e, portanto, pressupondo uma interface de comunicação natural para a pessoa de um especialista, mesmo admitindo-se que possam existir diversas outras formas de representar o mesmo universo de questão. Esse também é um pressuposto de qualquer projeto de construção de ontologia, que é sempre construída coletivamente e de modo colaborativo.

Assim, seguiram as perguntas abaixo e para elas o resultado apresentado sob a forma de gráfico de barras verticais, com os números absolutos e o percentual de incidência de respostas. Cabe lembrar que tais dados representam o grau de relevância de uma determinada classe no contexto de um processo de negócio, ou uma subclasse, uma vez que é naturalmente estruturada essa árvore do conhecimento sobre o processo de negócio e submetida aos que respondem o questionário, como um pressuposto da estrutura desse conhecimento. 
Para a classe "Conhecer", foram feitas as seguintes propostas:

Enunciado: Para "conhecer" um Processo de Negócio, atribua pesos aos tópicos abaixo:

\section{Regras/Normas do Negócio}

$\begin{array}{llllll}0 & 1 & 2 & 3 & 4 & 5\end{array}$

\begin{tabular}{l|l|l|l|l|l}
0 & 0 & 0 & 0 & 0 & 0
\end{tabular}

\section{Relevância:}

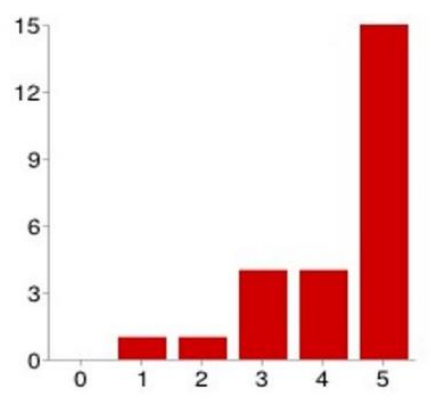

\begin{tabular}{|c|c|}
\hline \multicolumn{2}{|c|}{ Respostas/ Percentuais } \\
\hline 0 & $0 \%$ \\
\hline 1 & $4 \%$ \\
\hline 1 & $4 \%$ \\
\hline 4 & $16 \%$ \\
\hline 4 & $16 \%$ \\
\hline 15 & $60 \%$ \\
\hline
\end{tabular}

O entendimento/opinião dos pesquisados é de que o conhecimento de um processo de negócio depende fortemente do acesso às suas regras e normas, formais ou informais, já que não foi descartada nem uma ou outra natureza de regulamentação.

2. Organograma real e formal

$\begin{array}{llllll}0 & 1 & 2 & 3 & 4 & 5\end{array}$

\begin{tabular}{l|l|l|l|l|l}
0 & 0 & 0 & 0 & 0 & 0
\end{tabular}




\section{Relevância:}

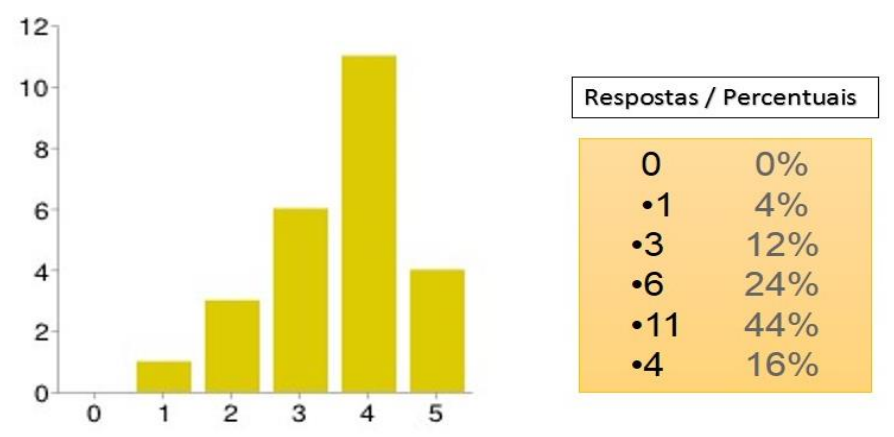

Embora sem a mesma quase unanimidade que a regra de negócio assumiu, o conhecimento sobre o organograma, é considerado altamente relevante pelos especialistas/pesquisados.

A distribuição das respostas, vista pela perspectiva do gráfico de barras que representa a sua visão estatística, mostra uma curva bastante próxima da curva normal, o que lhe aumenta o grau de aceitabilidade enquanto sua relevância para a compreensão e conhecimento de um processo de negócio.
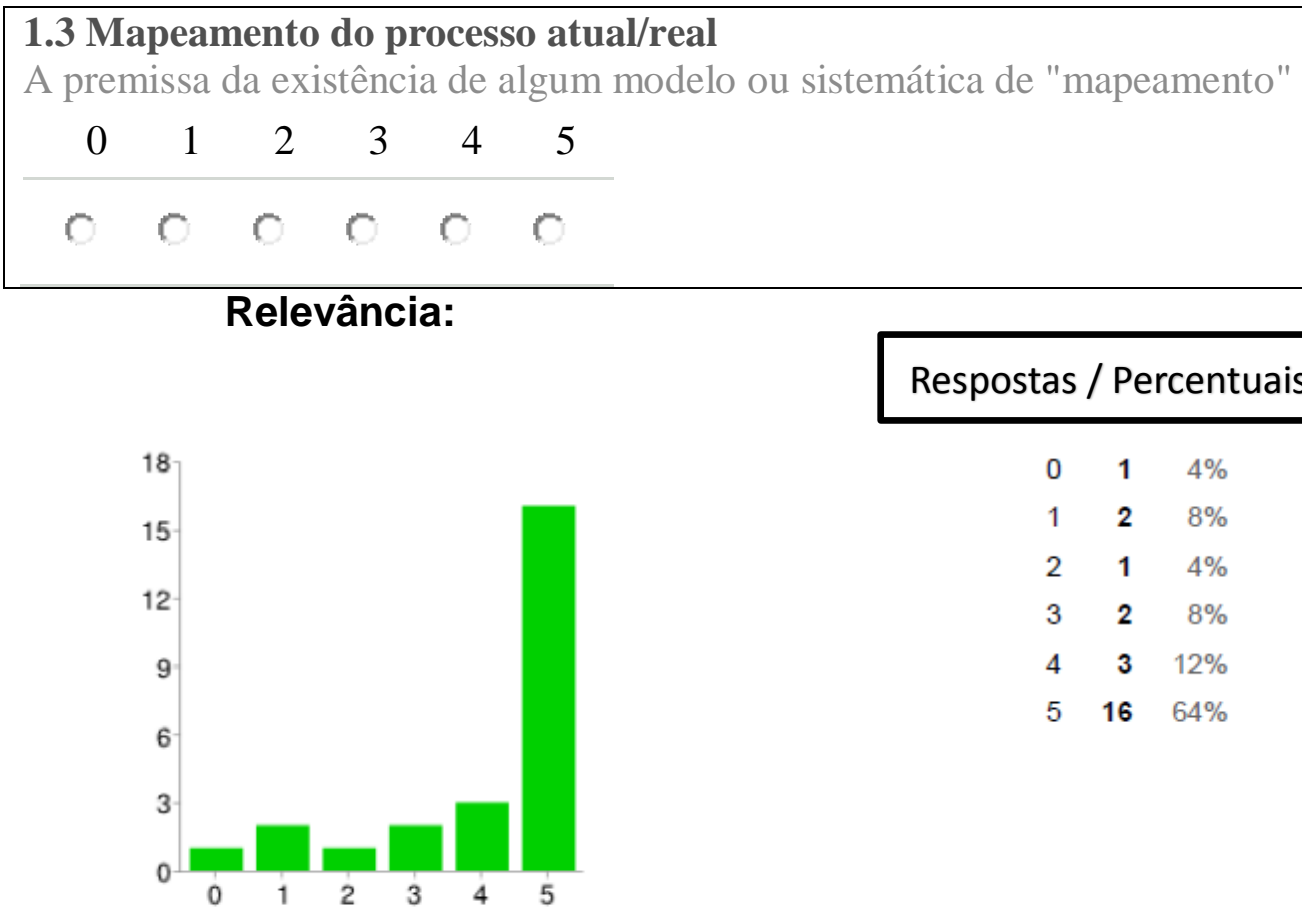

$\begin{array}{rrr}0 & \mathbf{1} & 4 \% \\ 1 & \mathbf{2} & 8 \% \\ 2 & \mathbf{1} & 4 \% \\ 3 & \mathbf{2} & 8 \% \\ 4 & \mathbf{3} & 12 \% \\ 5 & \mathbf{1 6} & 64 \%\end{array}$

Esse resultado demonstra um aspecto bastante importante da percepção dos especialistas sobre o processo de negócio, qual seja um quase consenso em relação à noção do 
"mapeamento" enquanto uma visão da arquitetura da rede de informações e dentro dele o processo de tomada de decisão.

A existência de escolhas que recaiam em níveis minimizados de relevância para a questão do mapeamento, tem algumas possíveis causas.

Uma delas seria o perfil de trabalho do pesquisado, onde revela que o mesmo se utiliza de outros sistemas de conhecimento do modelo decisório adotado no processo de negócio.

Outra possibilidade recai no fato de uma forma de coincidência de modus operandi dos pesquisados, que tem essa abordagem de levantamento apoiada no uso de recursos e artefatos de mapeamento do processo analisado.

O item seguinte se refere a avaliação da relevância dos documentos e formulários em uso nas organizações, sendo o resultado a seguir apresentado.

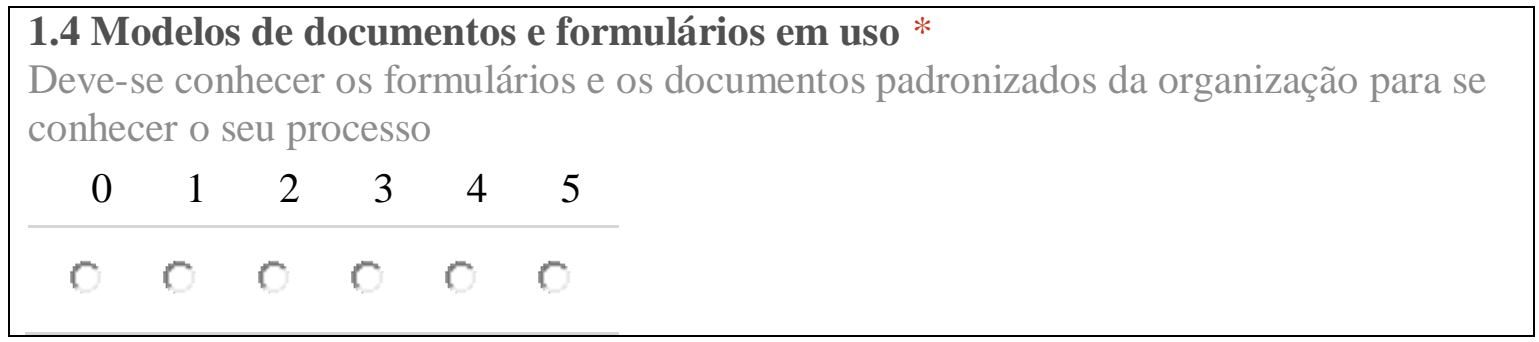

\section{Resultados:}

\section{Respostas / Percentuais}

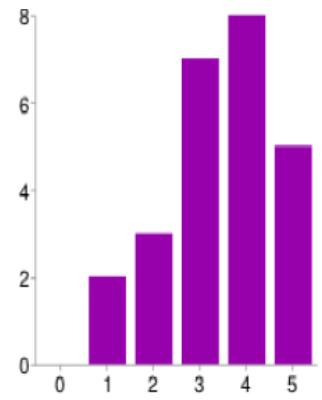

A distribuição dessas respostas chega a surpreender. Note-se que houve pouca relevância para a possibilidade de acesso aos modelos de documentos e formulários da organização, visando conhecer seus processos. 
Essa lógica seria básica mesmo que se tratasse da mais distinta e mesmo antiga forma de abordar a compreensão dos modelos de trabalho de uma organização, ainda que a pretensão fosse, por exemplo, a confecção de um sistema automatizado de informação ou a construção de um modelo de dados. Não seria comum mesmo em qualquer outro modus operandi que fosse adotado para compreender-se o estilo administrativo, o grau de burocratização, o processo decisório ou outras questões que revelem o caráter e o perfil da organização enquanto processo de negócio.

O item seguinte trata dos Sistemas, aplicativos e outros processos automatizados, que foi levantado como de interesse:

\subsection{Softwares e/ou Sistemas em uso}

Levantar, analisar e compreender os fluxos de informações e procedimentos existentes nos sistemas automatizados.

\begin{tabular}{l|l|l|l|l|l}
0 & 1 & 2 & 3 & 4 & 5 \\
\hline 0 & 0 & 0 & 0 & 0 & 0
\end{tabular}

\section{Relevância:}

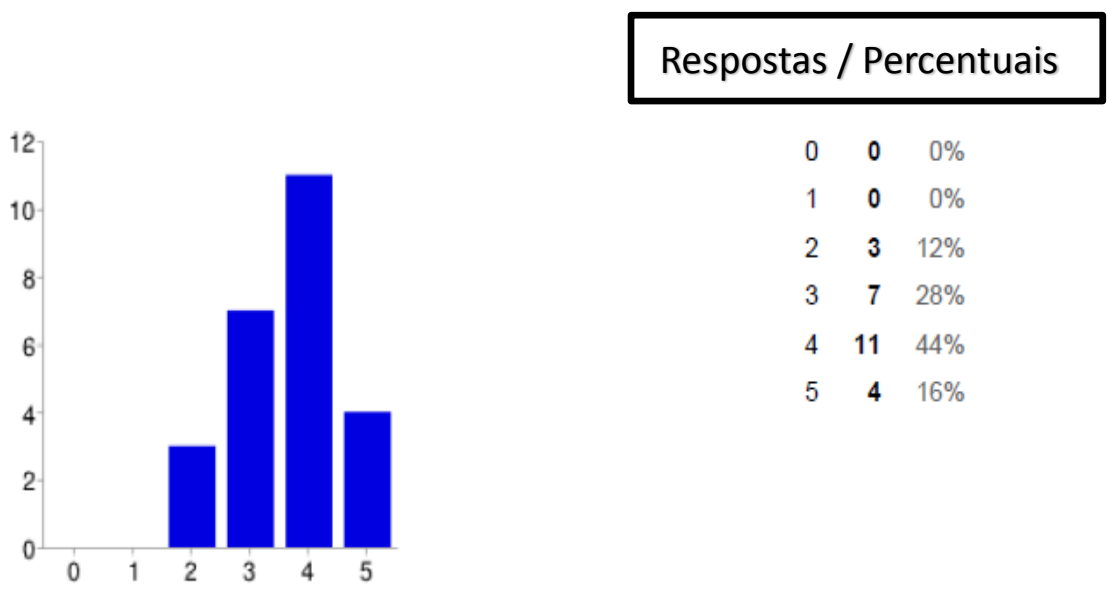

Essa pergunta também oferece uma tendência relacionada ao perfil dos profissionais, revelando um aspecto bastante destacado do profissional que lida diretamente com processo de negócio, seria consultoria e voltado para questões de engenharia e ergonomia do processo de negócio. 
Esses profissionais representam uma parcela relativamente pequena de pessoas com atuação especializada de tecnologia da informação e, portanto, pela sua perspectiva de atuação, para eles o processo de negócio poderia praticamente no todo ser visto pela lente dos sistemas automatizado, enquanto para outros tantos, oriundos de atividades mais do ramo de consultoria e organização, seria visto e compreendido por outros meios, como os modelos de decisão, níveis hierárquicos, etc. Portanto, a avaliação que por assim dizer valoriza ou superestima as questões de tecnologia da informação, seria atribuída muito mais aos profissionais que atuam justamente nessas áreas da tecnologia.

A predominância, no entanto, de profissionais que atuam em sistemas da ergonomia e inteligência corporativa, evidentemente, também percebem o grau de relevância dos sistemas automatizados, mas sabem e lidam principalmente com outros aspectos, muito mais próximos das questões executivas e da organização dos processos.

A partir do item a seguir, as respostas passam a avaliar as questões aqui classificadas como de natureza "subjetiva", pois estariam afetas a aspectos classificados como de grau elevado de abstração, sendo assim, analisados como uma categoria diferenciada, ou mesmo uma subclasse diferente da apresentada até este ponto do questionário e também atribuídas à classe do Conhecer do processo de negócio.

Essa categoria de perguntas, por outro lado, também pode ser entendida como indissoluvelmente vinculadas ao conhecimento de um processo de negócio e, em especial, um aspecto crítico do ponto de vista dos impactos que os mesmos provocam ou podem provocar dentre as razões de sucesso ou de fracasso das organizações.

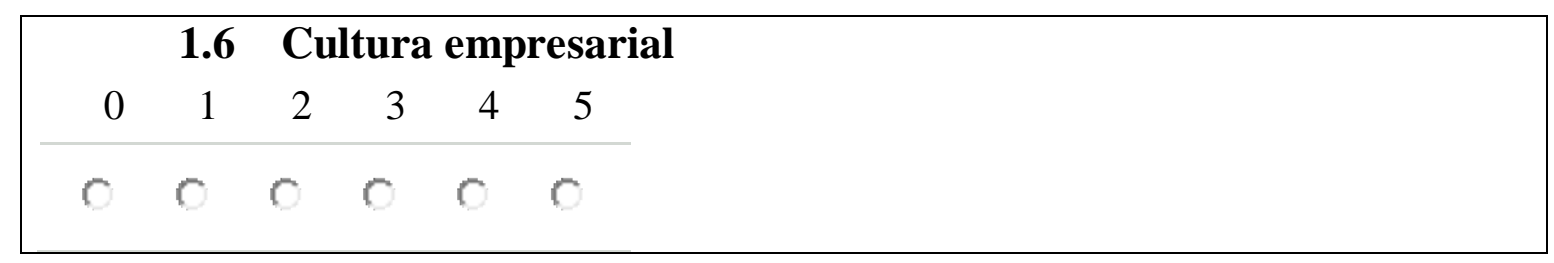




\section{Relevância:}

\section{Respostas / Percentuais}

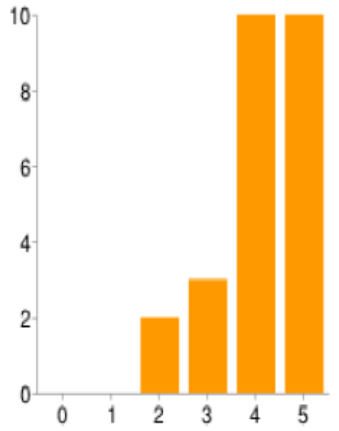

$\begin{array}{rrr}0 & 0 & 0 \% \\ 1 & 0 & 0 \% \\ 2 & 2 & 8 \% \\ 3 & 3 & 12 \% \\ 4 & 10 & 40 \% \\ 5 & 10 & 40 \%\end{array}$

A relevância que foi atribuída à cultura empresarial pelos pesquisados deixa entrever uma alta importância atribuída pelos especialistas ao aspecto humano, portanto, do processo de negócio.

Nessa realidade percebe-se ainda, em diversas formas de atuação dos consultores de mercado, visando o realinhamento da motivação dos colaboradores, seja diante de crises sazonais, seja para suprir a proposta de introdução de novos produtos e serviços ou mesmo novas metas que serão vislumbradas nos eventos de planejamento estratégico ou em momentos de reengenharia do processo de negócio global.

Percebe-se que a introdução de um fator subjetivo numa ontologia, experimenta um razoável grau de dificuldade, no que diz respeito à sua possível apropriação como regra de decisão ou de inteligência num sistema especialista qualquer.

No entanto, justamente por esse grau de incerteza, a sua validade aprovada por especialistas, torna-a um fator relevante para a compreensão de um processo de negócio.

Vale recuperar e relembrar que a proposta é de uma ontologia que permita compreender um fenômeno tipicamente em rede. Podendo essa classe de variável, quando e se necessário seu aproveitamento, ser também tratada sob a ótica de um modelo não-linear, ou seja, um modelo baseado em um grau de precisão relativa.

A análise dessa questão, no entanto, nos remete ao debate que perpassa o front que busca dialogar com a vasta produção de novas ontologias que ocorre em diversos redutos, 
seja por pesquisadores acadêmicos, seja em segmentos de grupos de discussão que se alinham visando produzir ontologias especializadas, pode ainda, a própria articulação de setores produtivos de empresas, que formam bases colaborativas e mesmo processos abertos e de interesse de comunidades diversas.

Essa profusão de novas coletâneas ontológicas, acabam por propiciar novos espaços para sistemas de buscas especializados e para a construção de grandes acervos de metadados sobre as mais diversas temáticas.

A produção semântica pode ter seu aproveitamento em franco vigor.

As análises das questões enumeradas de 1.7 até 1.10, seguem-se de maneira mais resumida, uma vez que a análise até aqui apresentada, na prática seria a mesma, ou apenas guardaria leves diferenças.

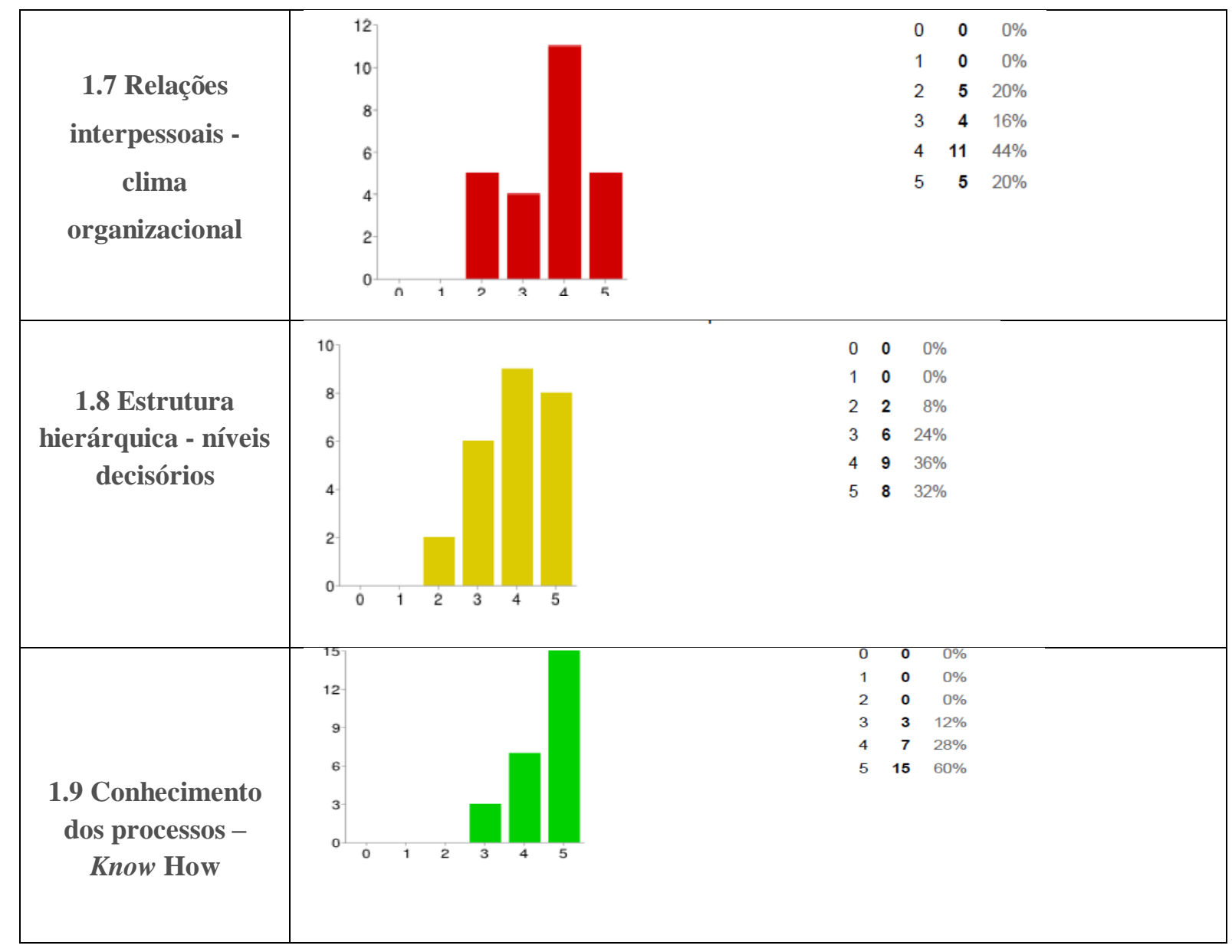




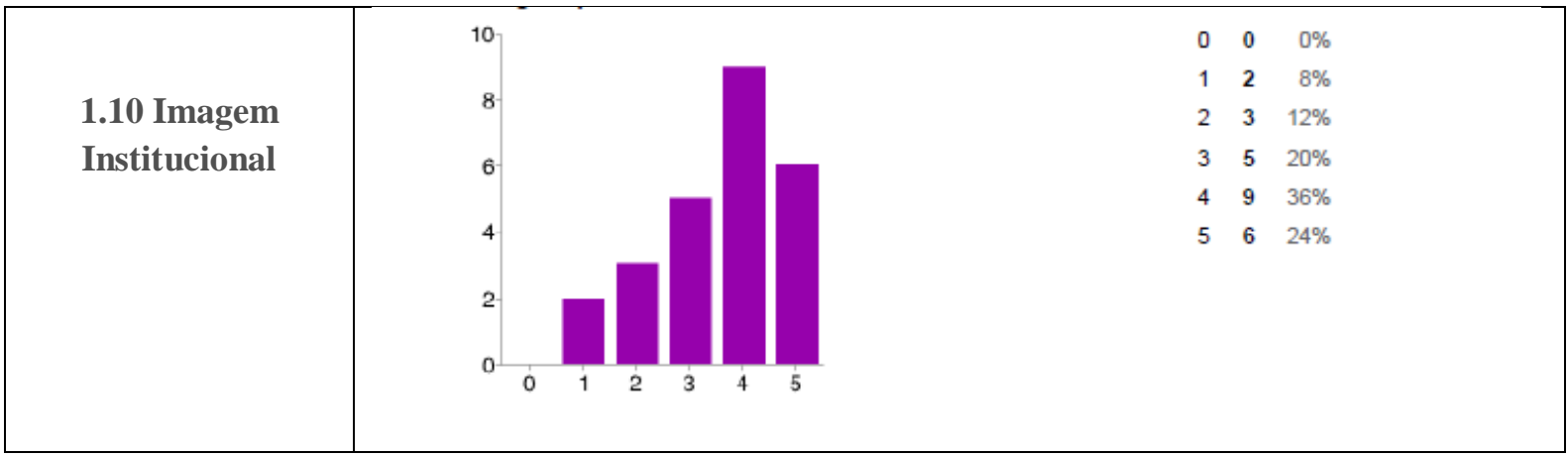

Avaliação da Classe do tipo interferir, que se refere às ações de mudança, reengenharia ou substituição do processo de negócio existente. Essa classe de ação é o lado mais delicado da chamada engenharia de processos, pois nela recaem as mais importantes expectativas relativas às possibilidades de intervenção no processo de negócio.

As questões selecionadas para buscar a opinião dos especialistas, naturalmente, esbarram num difícil dilema que representa uma tal empreitada. Isso acontece seja pela grande responsabilidade que representa quanto à própria sobrevivência da empresa, seja também pelos impactos na ecologia humana das organizações.

Isso pode também ser visto pelo peso que representa uma deliberação dessa natureza, quanto a tudo o que é depositado como de responsabilidade do especialista em processo de negócio, mormente quando a ele é atribuída a autoridade e o arbítrio para interferir num sistema produtivo em sua essência, resultados e, portanto, na sua sobrevivência.

Foram selecionados para essa amostra de relevância, os seguintes tópicos de uma ação de intervenção num processo existente:

a) Reescrever-se seus fluxos de trabalho - isso pressupõe uma forma de intervenção baseada no uso de ferramentas de automação, ou não, desde que interfiram diretamente no modus operandi do processo de negócio;

b) Reescrever e fazer conhecer novas regras e papéis - o processo de trabalho e, portanto, as formas de produção e decisão, nas organizações são orientados, via de regra, pela espontânea sistematização que, apesar de muitas vezes existirem regras e papéis definidos, principalmente com o decorrer do tempo, vão se orientando pelas condições disponíveis; artefatos muitas vezes recriados de soluções anteriores, sistemas reciclados; outras vezes contam com fluxos de informação que não respeitam as regras, estrito senso, criadas para orientar esses processos, entre outros aspectos. Resumindo essa 
subclasse, percebe-se que é através dela que são modificadas as estruturas produtivas nas organizações.

c) Criar um sistema/novo de workflow e GED - a força da automação está sempre presente na maioria dos cenários de mudanças e de transformação das empresas. Esse item sugere uma reflexão a respeito de sua relevância, sua importância num contexto de interferência de uma organização em mudança. Esse tipo de solução nem sempre é o único existente. Obviamente existem outras formas de se automatizar o processo de negócio. Mas este é um dos mais populares.

d) Promover treinamentos, palestras e workshops para mudança dos padrões humanos de trabalho - essa intervenção se dá no foro das pessoas, pressupondo que através de sua realimentação educativa e/ou seminários visando a mudança comportamental trarão impactos na atitude produtiva.

e) Mudar a estrutura organizacional e as funções dos atores - esse tipo de ação é muito utilizado pelas organizações públicas. O que se busca aqui é uma reflexão crítica sobre sua relevância e, portanto, sua eficácia enquanto impacto transformador do processo produtivo das organizações.

Esse conjunto de ações ou subclasses dentro de uma ontologia de estudos como a presente, implica em escolhas, as quais recaem, quase sempre, nos critério e arbítrio do pesquisador, ainda que apoiado ou referendado por um grupo de especialistas.

O que se busca, é trabalhar-se buscando justamente a maior presença de consenso ou o grau de dispersão de um olhar que busca atribuir relevância num processo de construção de uma ontologia, a ser consagrada em e para um contexto de caráter tão abrangente quanto o processo de negócio.

Segue abaixo os resultados das opiniões dos pesquisados quanto aos itens comentados e que são a proposta para a taxonomia de um modelo ontológico, no que diz respeito à interferência no processo de negócio.

Resultados da pesquisa: 


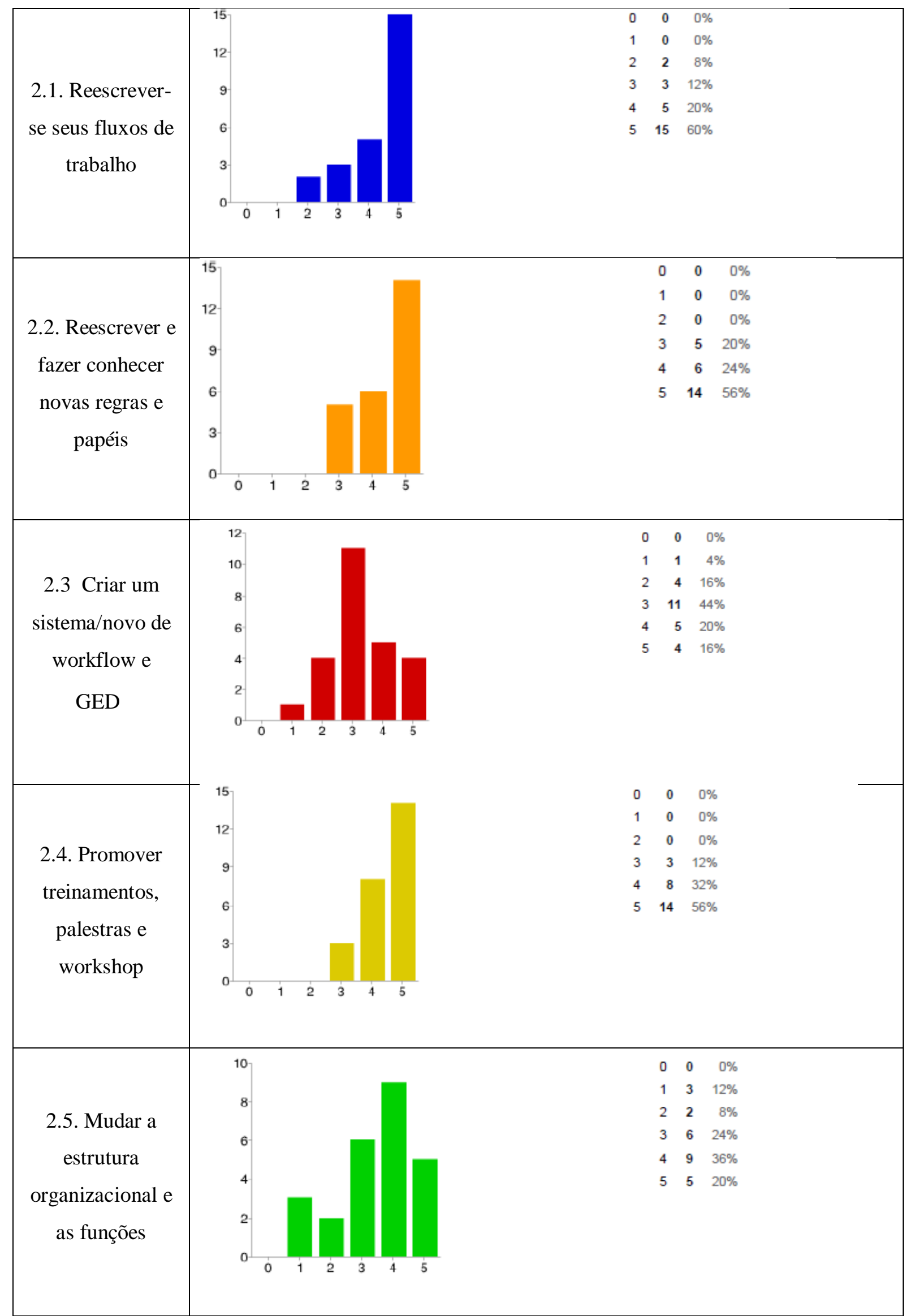


Quanto aos resultados obtidos, destaca-se os itens que tiveram alguma coincidência quanto ao maior grau de relevância do item pesquisado. Trata-se dos 2.1, 2.2 e 2.4, do questionário de pesquisa.

Essa escolha sistemicamente recaída na maior relevância dessas ações como parte das mais importantes formas de interferência num processo de negócio de uma empresa, revela a quase unanime forma de atuação dos profissionais consultores de processos.

Para esses profissionais, as principais ferramentas que dispõem para sugerir mudanças nas organizações recaem justamente nos treinamentos, fluxos de trabalho e reengenharia humana nas organizações.

Em grande parte, outras soluções, como as automatizadas, são produtos no mais das vezes de decisões internas das organizações. Parte pelo volume de recursos financeiros e pelo oneroso processo pelo qual passa a introdução de uma nova tecnologia e seus artefatos transformadores dos modelos de trabalho nas empresas.

Sob a premissa de que se trata de um profissional de alto custo e vasta qualificação, as organizações recorrem aos consultores de processo, para que lhes ajudem a proceder com suas mudanças ou melhorias.

Assim sendo, essa seria a mais natural forma, no contexto das empresas, de se intervir nos seus mecanismos produtivos. Portanto, a premissa de distorção acaba sendo aquilatada, pelo status quo do mercado.

No terceiro item do modelo, inseriu-se a ideia da Avaliação, como temática para os especialistas manifestarem suas opiniões. Lembrando que toda escolha requer uma renúncia, para modelar a semântica da Avaliação, enquanto fenômeno de uso corrente no contexto do processo de negócio, foram selecionadas cinco ações, segundo as quais se poderia compreender e avaliar o desempenho do processo de negócio.

Essas ações seriam:

a) Implantar ou recuperar os indicadores dos processos - os indicadores dos processos são as mais usadas fontes para alimentação da situação do processo de negócio. Sua utilização é uma das formas de se medir o estágio de maturidade do processo de Governança em TI, por exemplo. Também já foi mencionado neste trabalho, a face nativa dos indicadores, como subproduto dos fluxos automatizados através do uso de tecnologias workflow. Neste contexto, eles são utilizados com o papel de serem as fontes que irão subsidiar fortemente a classe de avaliação de um processo de negócio. 
b) Avaliar a satisfação dos clientes - essa subclasse de avaliação, é também amplamente utilizado pelas empresas, principalmente as que se sentem de algum modo ameaçadas pela concorrência ou simplesmente pela perda momentânea de mercados, ou sofrem qualquer forma de rebaixamento nas vendas. Como elemento de alimentação de um método de avaliação, aparece entre as propostas, a análise do grau de satisfação dos seus clientes ou usuários, visando uma maneira de verificar o grau de importância desse tio de avaliação e, portanto, da relevância que se reveste para o processo de negócio ser avaliado na sua performance e resultados frente a seus clientes.

c) Promover reuniões com os colaboradores e dialogar sobre o desempenho dos processos - essa abordagem quase sempre é utilizada como método de trabalho por consultores e por profissionais que atuam na área de processo de negócio. A sua inclusão nesta pesquisa busca compreender e apreender o grau de relevância com que é tratado pelos especialistas pesquisados.

d) Obter informações e dados juntos as controladorias - a controladoria é um processo permanente dentro das empresas, que se preocupa com a aderência dos processos às normas e padrões exigidos, como também, em alguns casos, possuem a guarda de informações contábeis e outros indicadores que podem ser utilizados para uma compreensão do processo de negócio.

Essas subclasses serviram, assim, para uma compreensão do nível de relevância com que são vistos pelos pesquisados, o que é demonstrado conforme os resultados que serão demonstrados a seguir.

Questão 3.1 - Uso dos indicadores (Implantar ou recuperar os indicadores dos processos) 


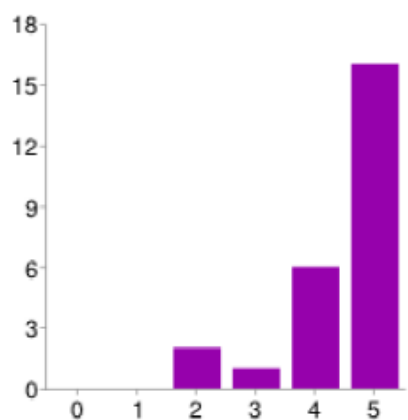

Os indicadores, como foi dito acima, se tornaram e a cada dia se consolidam como o grande modo de avaliação das organizações, mesmo em casos de sua aparente inexistência, pois até mesmo em balanços contábeis, no levantamento de números de transações e clientes, nos volumes de produção em diversos setores, sempre é neles que recai a principal fonte de compreensão do estado de coisas em que se encontra o desempenho das organizações.

Essa quase unanimidade observada na adoção dos indicadores retrata fortemente sua importância e sua extensão enquanto mecanismo de revelação da qualidade do processo de negócio e sua saúde produtiva.

As limitações dos indicadores aparecem justamente quando se busca utiliza-los e os mesmos se acham em desuso, ou desatualizados, ou mesmo não existem. Por isso, pela sua importância essa subclasse prevê até mesmo sua implantação, caso não existam.

Questão 3.2 - Grau de satisfação dos clientes (Avaliar a satisfação dos clientes):

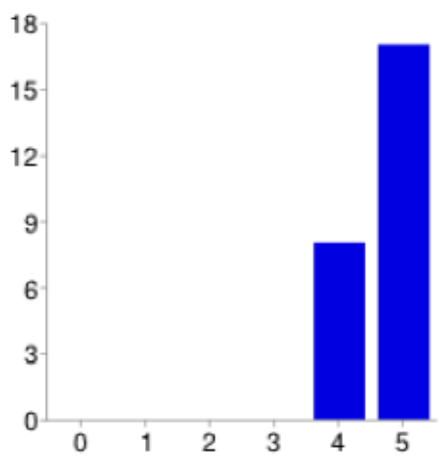

$\begin{array}{rrr}0 & 0 & 0 \% \\ 1 & 0 & 0 \% \\ 2 & 0 & 0 \% \\ 3 & 0 & 0 \% \\ 4 & \mathbf{8} & 32 \% \\ 5 & \mathbf{1 7} & 68 \%\end{array}$

A noção de cliente quase sempre parece recair em organizações de natureza comercial ou de prestação de serviços. No entanto, a premissa desta pesquisa, é que qualquer tipo de instituição tem algum público, clientela ou população para a qual destinar os resultados 
de sua atividade, até mesmo justificar sua existência, seja ela um discreto escritório de pesquisa ou análise, ou uma ONG que trabalhe apenas publicando dados analisados, lá estará, sempre, algum destinatário de seus resultados, seus produtos ou seus serviços.

No caso da empresa pública, algumas funções são de natureza tão discretamente visíveis que quase parecem não ter clientes. Mas de algum modo sempre os tem.

Essa a noção que passa o resultado da enquete junto a especialistas de processo de negócio, mesmo que alguns deles o classifiquem com relevância 4 (quatro) numa escala de 0 a 5 (zero a cinco).

Questão 3.3 - Entrevistas com os colaboradores (Promover reuniões com os colaboradores e dialogar sobre o desempenho dos processos)
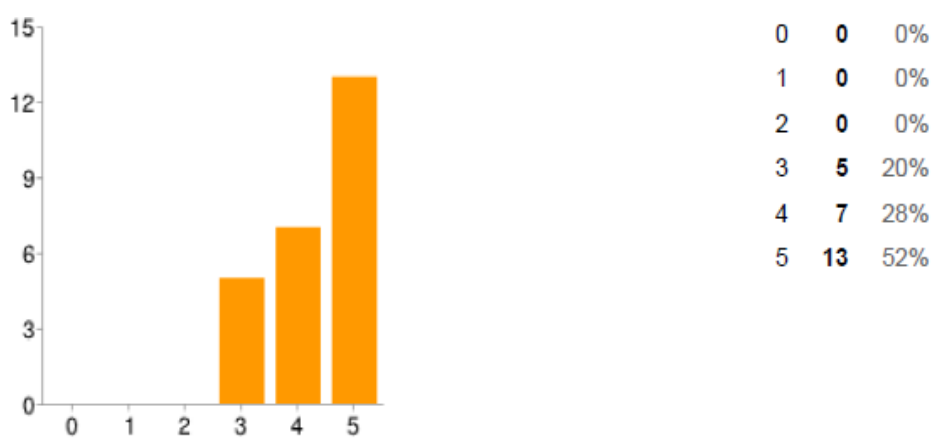

O fator humano é a unidade-chave, por assim dizer, de qualquer organização e, no entanto, a necessidade ou a deliberação em colocar essa dimensão sob a alça de mira de uma avaliação é uma decisão temerária. Particularmente em se tratando de organização governamental de qualquer nível.

Eis que a fragilidade dos mecanismos de avaliação, objetivos ou subjetivos, sempre tornam essa parcela dos processos sujeitas a uma grande margem de dúvida, quanto a sua eficácia, como forma de avaliação de uma instituição, ou um setor funcional específico.

Os métodos usados em uma certa fase da reengenharia de processos, produziu um grande volume de resistências, justamente porque buscou a sua fonte-chave de avaliação e de motor para mudanças nas pessoas. Esses ajustes, leia-se demissões, rebaixamentos de cargos e salários, remanejamentos arbitrários e outras formas de intervenção branca, como é chamada nos meios que atuam em consultoria de processos, provocou - e ainda provoca - um sem 
número de resistências, reações e formas abertas ou veladas de combater-se as engenharias dos processos.

A participação de pessoas na obtenção de informações também inclui o fato da delação, ou seja, quem ousaria a oferecer um julgamento muito sincero e abrangente sobre os problemas por traz das situações de baixa produtividade ou de entraves nos fluxos decisórios, ou mesmo em questão de cadeias de comando.

No entanto, essa subclasse necessariamente faz parte do acervo de fontes que permitem reconhecer e avaliar o processo de negócio e dele obter-se diagnósticos, pois são elementos básicos para qualquer tipo de intervenção, mudança, reorientação, revisão e outras formas de reengenharia do processo de negócio, mesmo não sendo os meios mais populares de atuação na reengenharia de processos.

Questão 3.4 - Obter informações e dados juntos a controladorias.

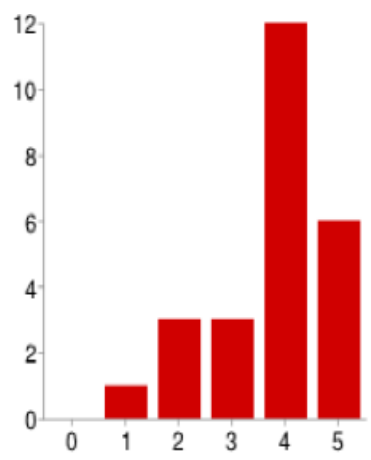

$\begin{array}{rrr}0 & 0 & 0 \% \\ 1 & 1 & 4 \% \\ 2 & 3 & 12 \% \\ 3 & 3 & 12 \% \\ 4 & 12 & 48 \% \\ 5 & 6 & 24 \%\end{array}$

Existem normalmente setores ou pessoas que se encarregam do acompanhamento e da governança dos processos nas organizações em geral e, no caso governamental, isso é uma exigência normativa para a garantia da transparência do uso de recursos públicos, contratações e outras questões de interesse do Estado. Esses setores, denominados normalmente controladorias, seriam fontes imprescindíveis para se avaliar um processo?

O modus operandi típico dos processos de controle interno e de governança, quase sempre se baseiam na manutenção de estoques de informações, dados e séries históricas do desempenho dos setores. 
Eles poderiam podem oferecer importantes contribuições para a avaliação de um processo produtivo, o seu desempenho histórico ou mesmo algum fator que, isoladamente ou não, tenha repercutido nos controles internos. Eles exercem o papel de intervir ou de recomendar ações e correções nos sistemas produtivos ou nos fluxos de informação. Certamente essa função precípua da controladoria e da governança são aliados imprescindíveis para a avaliação do processo de negócio. É essa a percepção que os especialistas deixam transparecer de sua opinião a respeito.

Questão 3.5 - Extrair log e informações a partir dos sistemas automatizados

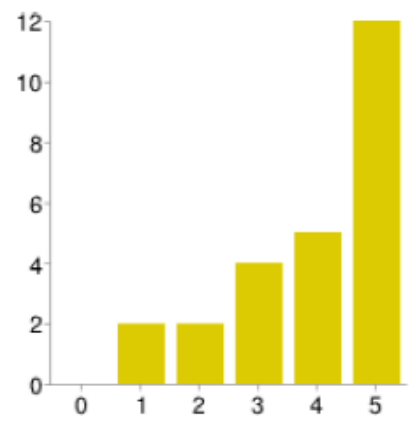

$\begin{array}{rrr}0 & \mathbf{0} & 0 \% \\ 1 & \mathbf{2} & 8 \% \\ 2 & \mathbf{2} & 8 \% \\ 3 & \mathbf{4} & 16 \% \\ 4 & \mathbf{5} & 20 \% \\ 5 & \mathbf{1 2} & 48 \%\end{array}$

Existem informações perenes e muitas vezes em grande variedade e grande volume, que registram informações sobre o desempenho dos sistemas, suas falhas, volumes, atores, etc. Essas informações podem/devem ou não ser utilizadas para avaliar os processos? É isso que se propõe ponderar em termos de relevância.

O perfil do consultor de processos, muitas vezes, precisa ser complementado por outros conhecimentos técnicos mais específicos e mais adequados para apoiar e compreender questões de natureza diversa daquela para a qual o consultor esteja preparado. Por isso, normalmente, a atuação das consultorias de processo se dá através de atuação em equipes multidisciplinares, no caso de empresas de grande porte ou de projetos bem específico de diagnóstico de avaliação em contextos complexos, como em data-centers ou outras estruturas de grande volume de informações e dados.

A utilização dessas fontes como se vê na opinião dos pesquisados, tem um número expressivo de relevância máxima. É praticamente impossível se pensar em um negócio qualquer sem a presença e a contribuição dos sistemas informatizados e, deles, para a compreensão dos processos produtivos e informações relevantes sobre eles. 
Embora o uso dessas informações não seja simplista, através da ajuda de especialista ou de uma ferramenta de mineração, se pode analisar grandes volumes de metadados dos sistemas de informação. Justamente, neste caso, busca-se os sinais e os registros de estrangulamentos dos meios de produção; a sobrecarga de informações; os tempos de conexão - indicativo muitas vezes de excessivas horas de trabalho, tornando-se os metadados dos sistemas automatizados de informação e dos mecanismos de automação em geral, uma fonte importante de informações que podem ser utilizadas para a avaliação do processo de negócio. 


\subsection{Uma arquitetura de Informação do Processo de Negócio}

O objetivo central desta dissertação é a obtenção de uma arquitetura de informação que possa representar o processo de negócio, baseada na ontologia do processo de negócio.

O trabalho até aqui empreendido buscou os elementos fundantes para tal arquitetura de informação do processo de negócio, objeto desta pesquisa.

A figura a seguir busca representar a arquitetura que se chegou neste estudo, da qual se desdobrará o tema e a argumentação da sua defesa.

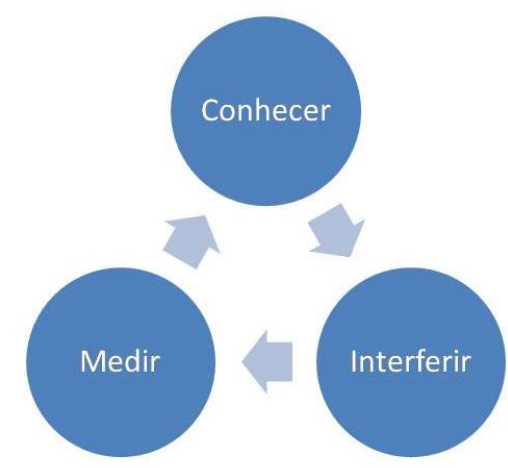

Figura 08 - Arquitetura do Processo de Negócio I

Macro ciclo do Processo de Negócio

(Fonte: criação do autor, 2015)

A estrutura representa os três pilares que sustentam qualquer abordagem relativa ao processo de negócio, tornando-se, assim, a fundação das suas classes mais abrangentes, que são:

A) O Conhecer - essa classe representa o conjunto dos aspectos cognitivos que envolvem um espaço informacional do processo de negócio e, assim sendo, parte de sua arquitetura. Isso se torna a forma de apropriação e representação do fenômeno do ponto de vista de sua compreensão e, portanto, a sua assimilação enquanto ser, sua existência ontológica, além dos aspectos relativos à sua rede de produção, seus atores, seus fundamentos e regras afins; 
B) O Interferir - na rota da engenharia do processo de negócio, existe quase sempre uma intenção transformadora, reformuladora ou, quando nada, atualizadora. Nesse sentido, a arquitetura precisa ter um pilar de definição em cima do qual se irá intervir, sendo ele o conjunto de elementos que comporão a ação, dando sentido de orquestração a qualquer mudança pretendida no processo de negócio. Instrumentos de intervenção serão parte desta estrutura, e compõem o contexto onde ela irá se desvanecer, do mesmo modo, caso não aconteça. O simples conhecimento dos elementos e subclasses desse pilar já permitiria um acervo de possibilidades, tanto para um gestor, quanto para um consultor no assunto.

C) O Avaliar - essa face do processo de negócio é talvez uma das mais adormecidas, do ponto de vista da realidade da média das empresas, mormente empresas públicas. Isso se dá às vezes por razões de autoproteção, formas de evitar o confronto com a realidade, por vezes adota-se uma relação discreta quanto à autocritica ou a crítica de atores e setores, por seu desempenho e produção apática num contexto de produção, servindo antes de munição para os confrontos de interesse ou a justificativa para a extinção de setores ou o seu rebaixamento, quanto a estruturas, organogramas ou orçamentos. Trata-se, ao que se vê, de um fenômeno de reações fortemente emocionais na maioria das empresas e mesmo em empresas privadas não se conhece, com raras exceções - as que mantenham constantemente os seus sistemas produtivos sendo monitorados, como recomendaria uma metodologia como o BSC - Balanced Scorecard, já que sua proposta é no sentido de uma avaliação constante dos indicadores, criando até mesmo um conceito de "painel de controle" através do qual se toma decisões e se promove ajustes.

A seguir é apresentada uma arquitetura expandida do processo de negócio, incluindo-se elementos pinçados das subclasses que foram inseridas no modelo taxonômico sugerido nesta dissertação.

Para representação dessa visão abrangente da arquitetura do processo de negócio, usou-se um modelo inspirado na notação Rich Picture, proposta como parte da metodologia denominada SSM - Soft System Methodology, citada na metodologia desta dissertação, onde utiliza-se elementos gráficos que se organizam de forma natural para representar um conceito, 
ou uma proposta ilustrativa de um fenômeno, como o que se busca demonstrar, ou seja, uma arquitetura inspirada na notação da técnica rich picture, do fenômeno aqui estudado.

\subsubsection{Arquitetura da Informação do Processo de Negócio II}

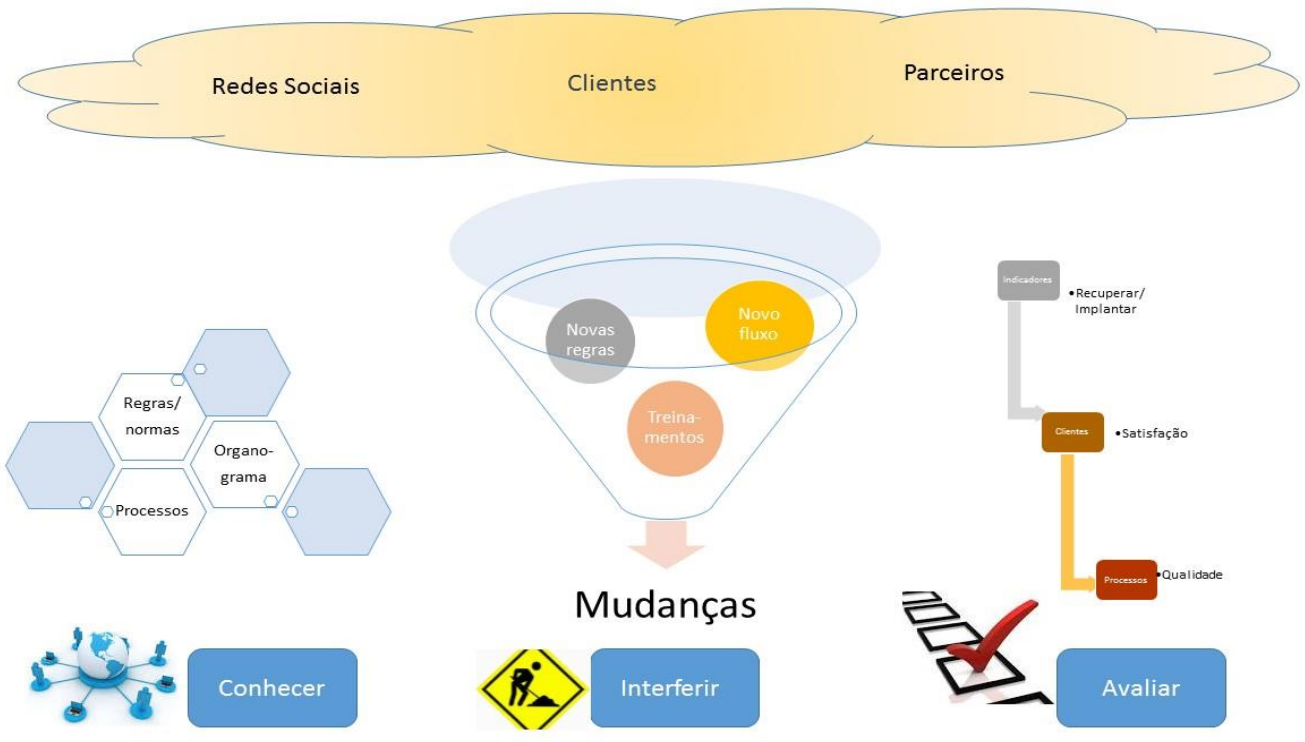

Figura 09: Rich Picture do Processo de Negócio

Fonte: criação do autor, 2015.

Nesta visão, incluem-se os elementos até aqui desarticulados de um contexto, no caso as subclasses que foram assim eleitas como parte da árvore de conhecimento que compõe o processo de negócio. Esses componentes são aqui vistos como subprocessos que compõem o processo de negócio, em outras palavras suas subclasses.

Na ilustração proposta, a articulação das classes e subclasses aparecem como parte do espaço informacional, ilustrando, de modo não linear a extensão da arquitetura do processo de negócio, tendo como complementos, as subclasses já apresentadas e que foram submetidas aos especialistas, tornando-se parte de sua convivência, nessa visualização também a nuvem da internet, pois sua existência, implícita, não poderia deixar de ser contemplada, como parte do espaço informacional, sendo assim imprescindível componente do processo.

Também se poderá, em estudos futuros, incluir-se neste modelo as questões de inovação latu sensu, que perpassaria todos os elementos do modelo, podendo afetar qualquer um deles, ou mesmo o modelo como um todo, caso surja novos insumos imprescindíveis. 


\subsubsection{Uma arquitetura em rede}

A ilustração a seguir é obtida de uma árvore hiperbólica, na qual foi desenhada uma arquitetura navegacional do processo de negócio, visando sua compreensão enquanto estrutura de conhecimento e de inteiração informacional.

Ela foi desenhada utilizando-se a ferramenta de software livre, Treebolic.

A diferença que essa organização da informação, como arquitetura, oferece é, justamente, a interatividade e a navegabilidade natural entre as classes e subclasses, que nessa abordagem se tornam nós de uma árvore ou rede de conhecimento.

Esse tipo de visualização - em árvore hierárquica, ofereceu para esta dissertação um casamento perfeito, ao que se pode perceber, para as taxonomias navegacionais, como a que foi construída nesta pesquisa e que serviu de porto para essa proposta de arquitetura, como se pode deparar da figura a seguir

A ilustração representada na Figura 10, é o flagrante de uma interface que permite a navegação na rede/árvore representada. Por essa ferramenta o leitor/usuário escolha qual das classes deseja visualizar especialmente e se desloca através do espaço de navegação, indo na direção do objeto que deseja melhor observar ou interagir.

Os nós centrais da rede são as classes e delas derivam suas subclasses, permitindo uma compreensão e direcionamento intuitivo e amigável.

Esse modelo, caso fosse do interesse, em sua construção se poderia incluir links de navegação, ícones ilustrativos e outros recursos, visando torna-la cada vez mais completa, em termos de conteúdo, como também articulada com outras fontes de sistemas informatizados ou simples objetos de outras bases.

A versão utilizada nesta pesquisa se limitou a trazer a representação das classes e subclasses e demonstrar sua interatividade, fazendo com que o tema do processo de negócio fosse demonstrado de modo navegacional em forma de rede/arvore do conhecimento do tema. 
Figura 10

Arquiteturas do processo de negócio - rede

Árvore Hiperbólica do Processo de Negócio

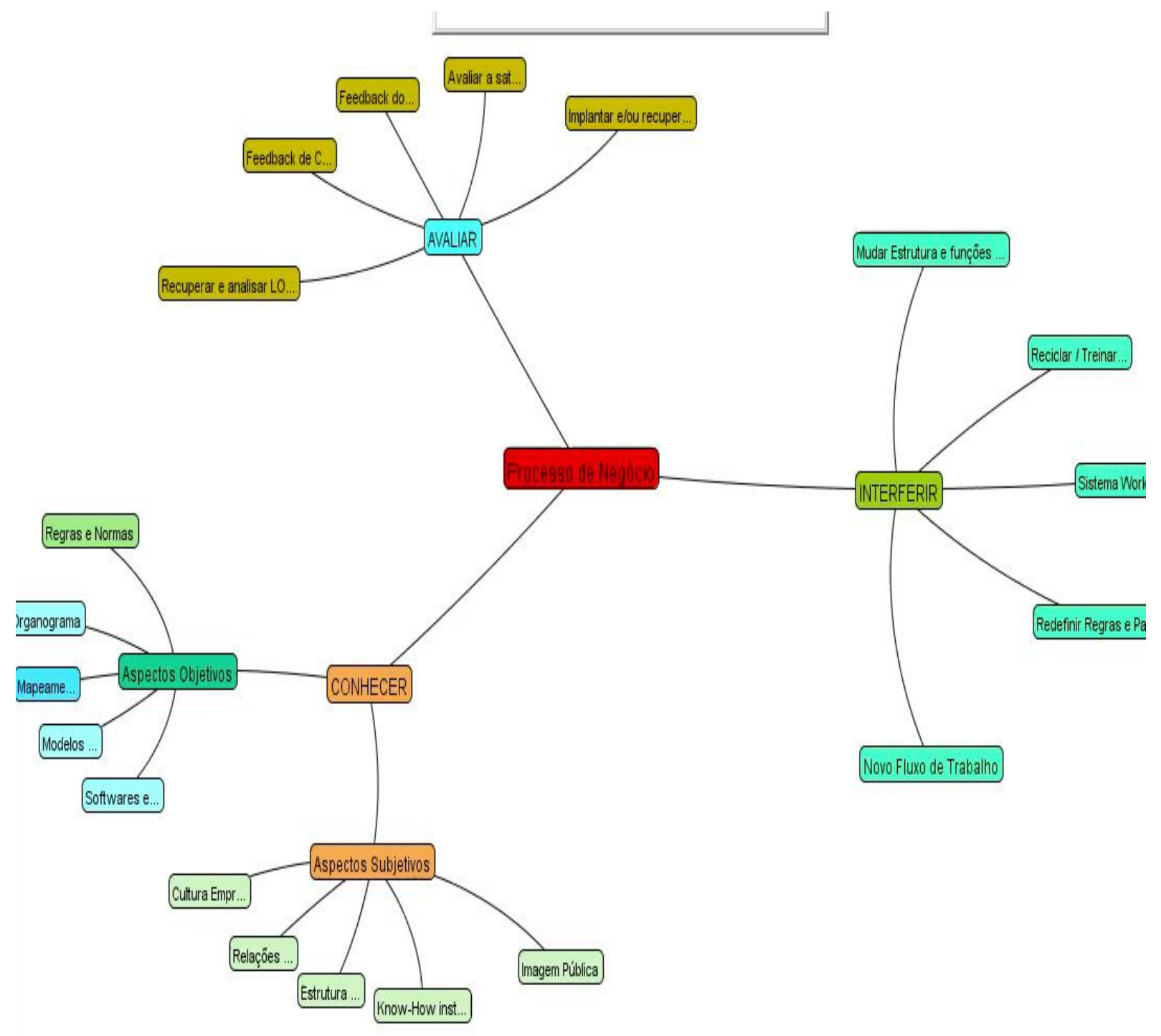

Fonte: criação do autor, 2015 


\subsection{Conclusão}

O objetivo geral desta pesquisa foi:

"Um estudo do fenômeno do processo de negócio como conceito de organização da informação, através de elementos de sua ontologia, visando a construção de uma arquitetura de informação sobre o tema".

As diversas nuances que perpassam o tema, ilustraram em diversos contextos deste trabalho, a diversidade de facetas do processo de negócio, enquanto fenômeno de forma, texto e contexto, tanto multidimensional, quanto multidisciplinar, além de trazer elementos, mobilizando um volume expressivo de produções a respeito, despertando o interesse tanto da comunidade acadêmica, quanto de profissionais do mercado de tecnologia e de serviços de consultoria.

No sentido, portanto, da organização da informação sobre o universo temático do processo de negócio, pode-se dizer que se obteve suficientes elementos para a proposição de uma arquitetura de informação sobre o fenômeno em questão.

Para a construção dessa arquitetura, foram obtidas importantes contribuições de profissionais do segmento, além do suporte de especialistas desse front, também, em entrevistas prévias à seleção e sistematização da pesquisa web, a qual apoiou a eleição de um conjunto de classes e subclasses para criar condições de compor um estudo da sua ontologia.

Com base nesse processo de produção intelectual, entende-se que se obteve os fundamentos para uma arquitetura amparada num estudo ontológico prévio do fenômeno estudado: o processo de negócio.

As versões arquiteturais modeladas, por outro lado, trouxeram propostas complementares à noção de formas de organização da informação sobre o fenômeno do processo de negócio.

Nesse sentido são apresentadas três diferentes opções para preencher essa proposta, ou seja, para representar a arquitetura da informação do processo de negócio. 
Portanto, considera-se que a pesquisa permitiu obter êxito na proposta e a produção de uma visão arquitetural, o que se desdobrou em três diferentes formas de representação da arquitetura almejada, quais sejam:

a) Arquitetura do macrociclo do processo de negócio (figura 08);

b) Arquitetura do processo de negócio sob a notação Rich Picture, (Figura 09), com a inclusão de algumas dimensões adicionais, em relação a primeira visão, quais sejam: as subclasses do processo de negócio, como também a dimensão da nuvem, onde encontram-se outros atores, eventualmente não claros na visão inicial dos três pilares:

c) Arquitetura baseada numa árvore hiperbólica, essa última (figura 10), destinada a uma opção navegável do modelo informacional e semântico, que oferece uma interface intuitiva e natural, a qual, embora faça parte de um universo taxonômico muito próprio e especializado, como, ademais, é característico das ontologias, permite uma compreensão intuitiva do fenômeno.

Outras metas que foram previstas na fase inicial, envolveram a pesquisa qualitativa da temática do objeto processo de negócio, através da seleção de estudos, acadêmicos ou técnicos, tendo como tema o processo de negócio, tendo sido lidos e aqui citados diversos deles, sendo admitido, a priori, a inviabilidade de se ter um levantamento de todo o universo a respeito, num flagrante de um momento de tão intensa movimentação que o assunto envolve.

Assim sendo, fixou-se no levantamento muito mais próximo do conceito de amostra bibliográfica, o que foi considerado, para a pretensão desta pesquisa, suficiente material, com o qual foi estabelecido diversos ângulos de debate e diálogo temático.

Também foi, em parte desses subsídios bibliográficos, que se obteve os elementos para a produção da estrutura ontológica e, antes, de uma taxonomia do processo de negócio, escolha que permitiu a construção de um arcabouço arquitetônico do espaço informacional do tema.

Nesse sentido, portanto, considera-se também suficiente, dentro do contexto e da pretensão deste pesquisador, o volume e a qualidade de subsídios que foram apropriados nesta dissertação.

Por fim, especificamente dentro das metas estabelecidas, a realização da pesquisa empírica foi realizada conforme planejada e, dela, diversas compreensões foram obtidas, 
cabendo destacar o caráter não-conclusivo, ou pelo menos não definitivo de que se reveste o estudo aqui realizado.

Do ponto de vista de uma visão incremental, o que se obteve foi apenas um ponto de partida, visando uma possível construção de uma ontologia definitiva a qual, pela sua natureza folksonômica, ou seja, tem sua alimentação e crescimento forjada na colaboração e, no sentido de sua plena abrangência e usabilidade, deverá vincular-se a uma comunidade de especialistas e dela obter sua vitalidade e aplicabilidade, seja em projetos de sistemas inteligentes (inteligência artificial) seja pela simples construção e compartilhamento de uma base ontológica do processo de negócio.

Em outras palavras, espera-se que esse tema seja eleito pela comunidade usuária para que o mesmo se beneficie desse interesse comum e dentro dele possa evoluir e ser incrementado.

Nesse sentido, as possibilidades do tema para novos estudos e pesquisas são grandes, dependendo apenas do despertar do interesse por quem de direito.

Por outro lado, do ponto de vista das hipóteses aventadas nesta dissertação, podese afirmar que as mesmas foram confirmadas na medida em que:

a) Hipótese: "O fenômeno estaria estreitamente ligado a questão epistemológica da organização da informação" - as referências e insumos teóricos e bibliográficas que foram inseridos neste estudo, demonstram que o tema tem sido do interesse da ciência da informação e de outras áreas da academia, representando, assim, que o tema tem relevância para a Ciência e, portanto, tem sua ligação epistemológica no seio da academia. Assim sendo, pode-se dizer que a hipótese foi confirmada pela pesquisa.

b) Hipótese - "Os elementos da taxonomia navegacional e da ontologia apoiariam a construção da organização da informação do fenômeno" - as propostas e respostas obtida nos modelos aqui apresentados, demonstram que essa hipótese obteve resposta afirmativa da pesquisa.

c) Hipótese - “A arquitetura da informação seria uma forma de representação que ajudaria na compreensão do fenômeno" - a pesquisa confirmou essa afirmação, na medida em que as figuras 08, 09 e 10 desta dissertação, ilustram formas arquiteturais sobre o tema da pesquisa, o processo de negócio, como consequência deste trabalho. 
Trabalhos futuros sobre o tema, poderão incluir a exploração de novos insights que a presente pesquisa não pode abordar, entre os quais incluir-se-ia:

$\checkmark$ A construção de modelo informatizado de ontologia do processo de negócio, que permita sua utilização em contexto de aplicação em sistemas de apoio à decisão, ou outros sistemas de informação especializado ou inteligência artificial;

$\checkmark$ A inserção de elementos de inovação, como parte do estudo do processo de negócio, sob a perspectiva de sua compreensão ontológica, a partir do uso de modelos que permitam o ensaio virtual de cenários, com a inclusão de novas tecnologias, novas abordagens ou outros insumos inovadores;

$\checkmark$ Outros estudos que o tema possibilite, não perceptíveis por este pesquisador e que possam trazer novas compreensões para o fenômeno aqui estudado, denominado processo de negócio. 


\section{Referências Bibliográficas}

ALBAGLI, Sarita. Divulgação científica: informação científica para a cidadania? Artigo. Revista Ci. Inf., Brasília, v. 25, n. 3, p. 396-404, set./dez. 1996.

ALBUQUERQUE, João P. Flexibilidade e Modelagem de Processo de negócio: uma relação multidimensional. Instituto de Ciências Matemáticas e de Computação, Universidade de São Paulo - São Paulo - SP, Brasil. RAE. Versão 52, n. 3. Maio/junho. 2012.

ALMEIDA, Maurício B. e BAX, Marcello P. Uma visão geral sobre ontologias: pesquisa sobre definições, tipos, aplicações, métodos de avaliação e de construção. Artigo. Ciência da Informação. v. 32, n. 3, p. 7-20, set./dez. Brasília, 2003.

CAVALCANTE, Rafael Silva. Critérios para avaliação de taxonomias navegacionais em sítios de comércio eletrônico. Dissertação de mestrado. Orientadora: Marisa Bräscher Basílio Medeiros. FCI/UnB. 2012.

SERACEVIC, Tefko. A natureza interdisciplinar da ciência da informação. Artigo. Revista Ciência da Informação - Vol. 24, número 1, 1995.

CHECKLAND, P. and POULTER, J. Learning for Action. New York, NY (2000).

CHECKLAND, P. Retrospective; Systems Research and Behavioral Science. John Wiley \& Sons, Ltd. 2000.

, Soft Systems Methodology: A Thirty-Year Retrospective. (2000)

COSTA, Lourenço. Formulação de uma metodologia de modelagem de processo de negócio para implementação de workflow. Dissertação de Mestrado em Engenharia de Produção. Universidade Tecnológica do Paraná. 2009.

COSTA, Reginaldo S. A adoção de árvores hiperbólicas como instrumentos de representação de conhecimento nos sistemas de informação multimodais. Artigo. IV Encontro Ibérico EDICIC 2013 (Associação de Educação e Investigação em Ciência da Informação de Iberoamérica e do Caribe). Universidade do Porto. Portugal. Novembro, 2013. 
Uso da árvore hiperbólica como suporte à rede de comunicação estratégica corporativa. Artigo. Simpósio Ibero-Americano de Gestão do Conhecimento e Inteligência GECIC. Curitiba - PR. Agosto2006

COSTA, Reginaldo S. e MEDEIROS, Sérgio Palmas J. Workflow Pragmático e sem Limites. Livro no prelo. 2001.

DZIEKANIAK, Gisele; PACHECO, Roberto; KERN, Vinicius Medina. Revisitando a organização do conhecimento através dos tesauros, folksonomias e ontologias: aportes da engenharia do conhecimento. In: SILVA, Fabio Couto Corrêa da; SALES, Rodrigo de (org.). Cenários da organização do conhecimento: Linguagens documentárias em cena. Brasília: Thesaurus, 2011, p. 201-237.

DUQUE, C. G (organizador). Ciência da Informação - Estudos e Práticas. Brasília. Centro Editorial. 2011.

DUQUE, Cláudio Gottschalg; A Leitura em Ambiente Multimídia, a produção de inferências por parte do leitor a partir da compreensão de hipertextos Tese de Doutorado da UFMG, 1998.

HEPP, M., Roman, D. An Ontology Framework for Semantic Business Process Management. University of Innsbruck. Austria. 2007.

GUMIEIRO, Katiúcia Araújo. Modelo de negócios para periódicos científicos eletrônicos de acesso aberto. Dissertação de Mestrado em Ciência da Informação. CID/UnB. Orientador. Dra. Sely Maria de Souza Costa. 2009.

KRESS, Gunter and VAN LEEUWEN, Theo. The Grammar of Visual Design, UCL Press, London. 2006.

LAVALLE, A. Gurza, Castello, Graziela e Bichir, R. Mirandola. Os bastidores da Sociedade Civil. CEBRAP. São Paulo. 2006.

LE COADIC, Ives-François. A ciência da informação. Tradução de Maria Yêda F. S. de Figueiras Gomes. 2a . Ed., revisada e atualizada. Brasília. Briquet de Lemos / Livros. 2004. LIMA-MARQUES, M.; MACEDO, F. L. O. Arquitetura da Informação: base para a Gestão do Conhecimento. In: TARAPANOFF, K. (Org.). Inteligência, informação e conhecimento. Brasília, DF: IBICT/UNESCO, 2006. 
LIMA-MARQUES, M. Ontologias, da filosofia à representação do conhecimento. Livro.

Editora Thesaurus. Brasília-DF. 2006.

MACHADO, Cesar de Souza e FISCHER, Norberto. Aplicação da Metodologia Rummler Bräscher Group na Implantação da Norma ISO17799. XXII Encontro Nacional de Engenharia de Produção. Curitiba - PR. Outubro, 2002.

MATIAS-PEREIRA, José. Manual de Metodologia da Pesquisa Científica. Livro. Editora Atlas. $2^{\mathrm{a}}$ ed. 2010.

MATTOS, Talita da C.; SANTORO, Flavia Maria, REVOREDO, Kate e NUNES, Vanessa T. Formalizando Contexto em Processo de negócio. VIII Simpósio Brasileiro de Sistemas de Informação - SBSI. Trilhas Técnicas, pág. 186 a 197. 2012.

MIRANDA, Z. J. G. Mapeamento de sistemas baseados em arquitetura da informação, monografia de conclusão do curso de pós-graduação latu-sensu Inteligência Organizacional e Competitiva na Sociedade da Informação, orientador Prof. - Doutor Mamede Lima Marques, UnB/CID, Brasília, 2006.

NONAKA, Ikujiro e TAKEUCHI, Hirotaka. Criação de Conhecimento na Empresa. Livro. Ed. Elsevier. Brasil. 2003.

OLIVEIRA, Carlson Batista. Uma proposta de Arquitetura da Informação para o processo de inovação em centros de pesquisa. Tese de doutorado. UNB/FCI/CPAI. Orientador. Prof.-Dr. Mamede Lima-Marques. 2012.

PAIVA, Rodrigo O. Uma Anatomia da Arquitetura da Informação. XXXV ENEBD. Múltiplos Olhares em Ciência da Informação, v.2, n.2. Belo Horizonte - MG. 2012. PINTO, Joaquim António P. e DAVID, Ma Manuela Soares. Resolução de Problemas: conceptualização, concepções, práticas e avaliação. Artigo. Depto. de Matemática. Universidade do Porto. Portugal. 2003.

ROBREDO, J. Da Ciência da Informação Revisitada aos Sistemas Humanos de Informação. Brasília. Thesaurus. 2003.

ROBREDO, J. Sobre arquitetura da informação. Artigo. Revista Iberoamericana de Ciência da Informação (RICI), v.1 n.2. 2008.

SADIQ, Wagar e RACCA, Felix. Business Services Orchestration - The Hypertier of Information Technology. Cambridge Information Technology. 2003. 
SANTOS, Monick T.; CORREA, Renato A. e SILVEIRA, Murilo A. A. Estudos brasileiros sobre ontologia na Ciência da Informação. Artigo. DataGramaZero. Revista de Informação vol. 14 n. 1. Fev/2013.

SHIESSL, Marcelo \& BRÄSCHER, Marisa. Ontologia: ambiguidade e precisão. Encontros Bibli: revista eletrônica de biblioteconomia e ciência da informação, v. 17, n. esp.1. 1012.

SILVA, Eliane M. Pereira e DUQUE, Cláudio D. O que é Teoria da Relevância? Texto. PPGCINF/UnB. Março. 2013.

SOUTO, Guilherme P. Contribuições para melhoria da Gestão Organizacional por intermédio do Processo de Negócios. Dissertação de Mestrado. Orientador: Prof.-Dr. Luís Fernando R. Molinaro. Faculdade de Tecnologia. Departamento de Engenharia Elétrica. UnB. 2011. TOMANIK, Eduardo Augusto. O Olhar no Espelho: “conversas" sobre pesquisa em Ciências Sociais. Livro. $2^{\text {a }}$ ed. 2004.

WURMAN, Richard Saul. Information Arquitects. Livro. Ed. Paperback. 1997.

\section{Outras Referências:}

http://www.inf.pucrs.br/ontolp/downloads-organizacional.php

http://www.bce.unb.br/normas-bibliograficas/ 


\section{Pesquisa acadêmica sobre Processo de Negócio}

Este formulário é parte de uma pesquisa acadêmica de mestrado, que se destina a operacionalizar e registrar a opinião de especialistas com larga experiência na consultoria, pesquisa, engenharia ou reengenharia de processos. Entre os quais você, que está lendo essas informações e que é considerado pelo pesquisador e autor desta pesquisa um especialista e uma referência no campo do processo de negócios. Seu preenchimento é bastante simples e rápido e só tomará alguns minutos do seu tempo! Desde já agradeço muito sua atenção.

Reginaldo S Costa

*Campo Obrigatório

Identificação dos participantes.

Este breve quadro pretende uma visão do nível de conhecimento das pessoas que participam da pesquisa sendo impessoal. Nenhum dado pessoal será requerido.
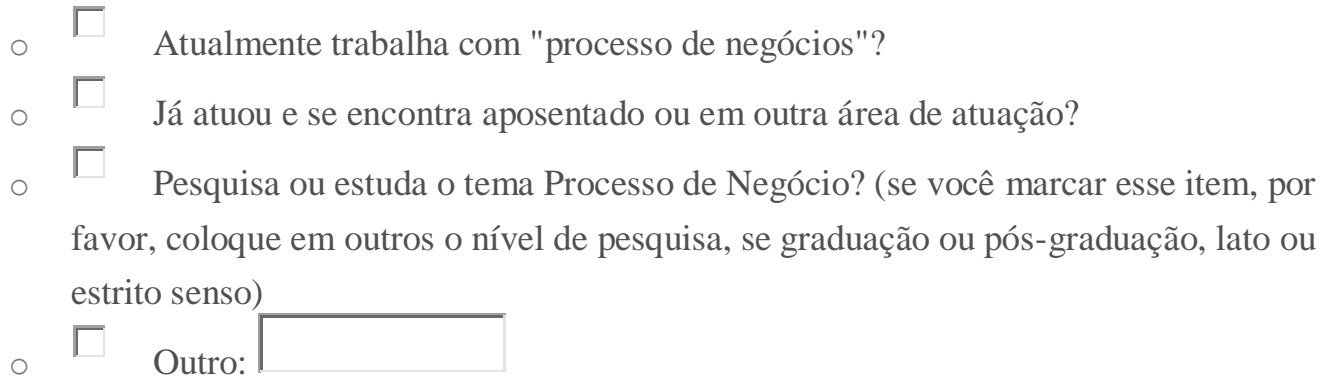

Classifique a relevância dos itens abaixo, segundo seu entendimento!

Classifique os tópicos abaixo na escala de 1 a 5

\begin{tabular}{llllllll|l|l|l} 
& 0 & 1 & 2 & 3 & 4 & 5 & \\
\hline Sem nenhuma relevância & 0 & $C$ & $C$ & 0 & 0 & 6 & Relevância máxima
\end{tabular}

Para "conhecer" um Processo de Negócio, atribua pesos aos tópicos abaixo: *

Regras/Normas do Negócio

$\begin{array}{llllll}0 & 1 & 2 & 3 & 4 & 5\end{array}$ 


\begin{tabular}{l|l|l|l|l}
0 & 0 & 0 & 0 & 0
\end{tabular}

Organograma real e formal *

Organograma real e formal

\begin{tabular}{l|l|l|l|l|l}
0 & 1 & 2 & 3 & 4 & 5 \\
\hline 0 & 0 & 0 & 0 & 0 & 0
\end{tabular}

Mapeamento do processo atual/real *

A premissa da existência de algum modelo ou sistemática de "mapeamento"

$\begin{array}{llllll}0 & 1 & 2 & 3 & 4 & 5\end{array}$

\begin{tabular}{l|l|l|l|l|l}
0 & 0 & 0 & 0 & 0 & 0
\end{tabular}

Modelos de documentos e formulários em uso *

Deve-se conhecer os formulários e os documentos padronizados da organização para se conhecer os seus processos.

$\begin{array}{llllll}0 & 1 & 2 & 3 & 4 & 5\end{array}$

\begin{tabular}{l|l|l|l|l|l}
0 & 0 & 0 & 0 & 0 & 0
\end{tabular}

\section{Softwares e/ou Sistemas em uso *}

Levantar, analisar e compreender os fluxos de informações e procedimentos existentes nos sistemas automatizados.

\begin{tabular}{l|l|l|l|l|l}
0 & 1 & 2 & 3 & 4 & 5 \\
\hline & 0 & 0 & 0 & 0 & 0
\end{tabular}

Quanto aos aspectos subjetivos do conhecimento sobre um Processo de Negócios, atribua sua opinião sobre a relevância dos tópicos abaixo. *

Cultura empresarial

$\begin{array}{llllll}0 & 1 & 2 & 3 & 4 & 5\end{array}$


Relações interpessoais - clima organizacional *

A obtenção sistemática e profissional do grau de equilíbrio, satisfação e harmonia entre os atores da organização.

\begin{tabular}{l|l|l|l|l|l}
0 & 1 & 2 & 3 & 4 & 5 \\
\hline 0 & 0 & 0 & 0 & 0 & 0
\end{tabular}

Estrutura hierárquica - níveis decisórios *

A quantidade de passos verticais existentes para que uma decisão seja tomada nos processos da organização.

\begin{tabular}{l|l|l|l|l|l}
0 & 1 & 2 & 3 & 4 & 5 \\
\hline & 0 & 0 & 0 & 0 & 0
\end{tabular}

Conhecimento do (s) Processo Produtivo (know-how) *

A existência de meios de se conhecer e avaliar o grau de autonomia dos processos produtivos.

\begin{tabular}{l|l|l|l|l|l}
0 & 1 & 2 & 3 & 4 & 5 \\
\hline 0 & 0 & 0 & 0 & 0 & 0
\end{tabular}

\section{Imagem pública institucional *}

Grau de satisfação dos clientes, dos parceiros e governo, em relação à confiabilidade da organização.

\begin{tabular}{llllll|l}
0 & 1 & 2 & 3 & 4 & 5 \\
\hline 0 & 0 & 0 & 0 & 0 & 0
\end{tabular}

Para interferir num Processo de Negócio, defina o grau de relevância dos seguintes itens. *

Criar e documentar um novo fluxo de trabalho

$\begin{array}{llllll}0 & 1 & 2 & 3 & 4 & 5\end{array}$


Reescrever e fazer conhecer novas regras e papéis *

Resultado de qualquer forma de rever os processos, haveria a necessidade de se reescrever ou revisar as regras e os papéis existentes. Ou não.

\begin{tabular}{l|l|l|l|l|l}
0 & 1 & 2 & 3 & 4 & 5 \\
\hline 0 & 0 & 0 & 0 & 0 & 0
\end{tabular}

Criar um sistema/novo de workflow e GED *

Existe sempre a necessidade de se utilizar uma ferramenta de automação?

\begin{tabular}{l|l|l|l|l|l}
0 & 1 & 2 & 3 & 4 & 5 \\
\hline 0 & 0 & 0 & 0 & 0 & 0
\end{tabular}

Promover treinamentos, palestras e workshop para mudança dos padrões humanos de trabalho*

\begin{tabular}{l|l|l|l|l|l}
0 & 1 & 2 & 3 & 4 & 5 \\
\hline 0 & 0 & 0 & 0 & 0 & 0
\end{tabular}

Mudar a estrutura organizacional e as funções dos atores *

Existem padrões de trabalho que sempre busca interferir na estrutura organizacional. Você concorda?

\begin{tabular}{ll|l|l|l|l}
0 & 1 & 2 & 3 & 4 & 5 \\
\hline 0 & 0 & 0 & 0 & 0 & 0
\end{tabular}

Para medir a situação, eficiência ou a eficácia de um Processo de Negócio, defina o grau de relevância dos itens a seguir. *

Implantar ou recuperar os indicadores dos processos
0
1
2
3
4
5 
\begin{tabular}{l|l|l|l|l}
0 & 0 & 0 & 0 & 0
\end{tabular}

Avaliar a satisfação dos clientes *

Seria esse um processo permanente de se medir a eficiência e a eficácia dos processos?

\begin{tabular}{l|l|l|l|l|l}
0 & 1 & 2 & 3 & 4 & 5 \\
\hline & 0 & 0 & 0 & 0 & 0
\end{tabular}

Promover reuniões com os colaboradores e dialogar sobre o desempenho dos processos *

\begin{tabular}{l|l|l|l|l|l}
0 & 1 & 2 & 3 & 4 & 5 \\
\hline 0 & 0 & 0 & 0 & 0 & 0
\end{tabular}

Obter informações e dados juntos a controladorias. *

Existem quase sempre setores ou pessoas que se encarregam do acompanhamento e da governança dos processos. Eles seriam fontes imprescindíveis para se avaliar um processo?

\begin{tabular}{l|l|l|l|l|l}
0 & 1 & 2 & 3 & 4 & 5 \\
\hline 0 & 0 & 0 & 0 & 0 & 0
\end{tabular}

Extrair log e informações a partir dos sistemas automatizados. *

Existem informações perenes e de grande volume sobre o desempenho dos sistemas, suas falhas, volumes, atores, etc. Essas informações podem/devem ser utilizadas para avaliar os processos?

\begin{tabular}{c|c|c|c|c|c}
0 & 1 & 2 & 3 & 4 & 5 \\
\hline 0 & 0 & 0 & 0 & 0 & 0 \\
\hline
\end{tabular}

Nunca envie senhas em Formulários Google. 
Apêndice B

Resultados estatísticos da pesquisa - formato web

\section{5 respostas}

\section{Resumo}

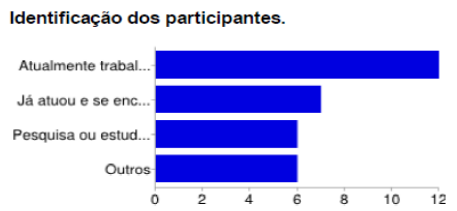

Atualmente trabalha com "processo de negócios"?

Já atuou e se encontra aposentado ou em outra área de atuação?
Pesquisa ou estuda o tema Processo de Negócio? (se vocé marcar esse item, por favor, coloque em outros o nivel de pesquisa, se graduação ou pós-graduação, lato ou est Outros

Classifique a relevância dos itens abaixo, segundo seu entendimento!

2

$\begin{array}{lll}0 & 1 & 4 \% \\ 1 & 0 & 0 \%\end{array}$

$200 \%$

(1)

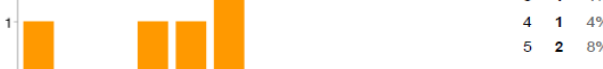

$\begin{array}{lllllll}0 & & & & & & \\ 0 & 1 & 2 & 3 & 4 & 5\end{array}$
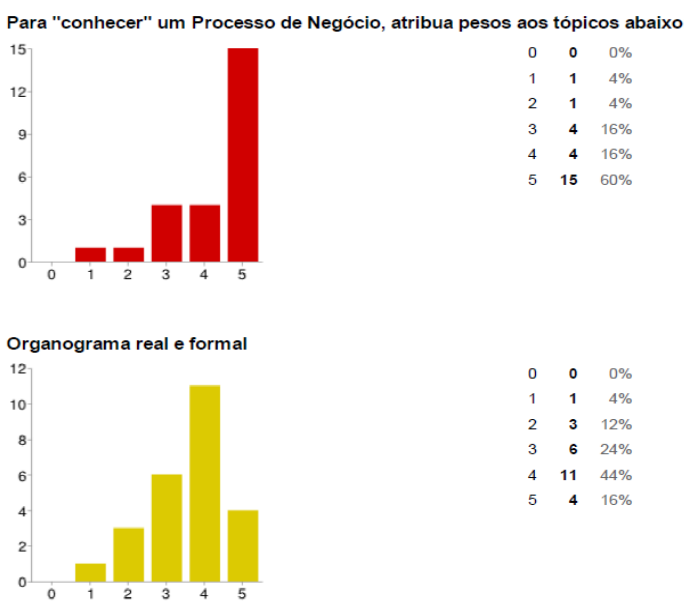
$21 / 04 / 2015$

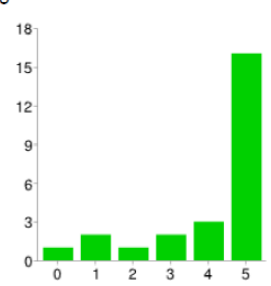

Modelos de documentos e formulários em uso
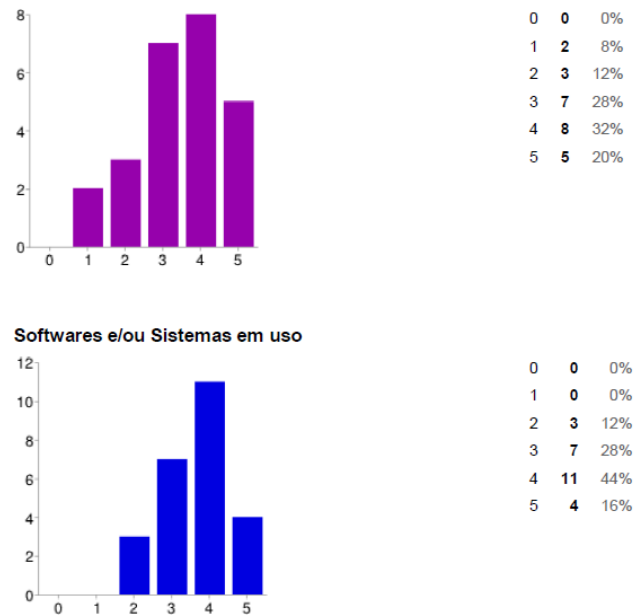

Quanto aos aspectos subjetivos do conhecimento sobre um Processo de Negócios, atribua sua opiniäo sobre a relevância dos tópicos abaixo.

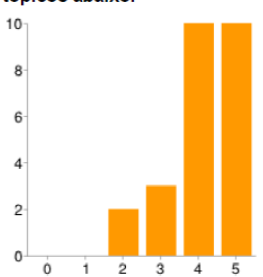

Relaçöes interpessoais - clima organizacional

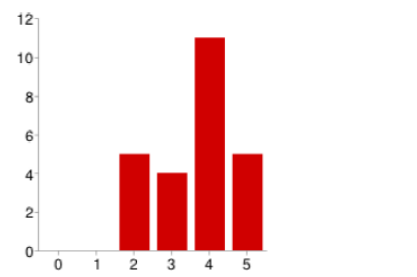

Estrutura hierárquica - niveis decisórios
Pesquisa acadêmica sobre Processo de Negócio - Formulários Google

$0 \quad 1 \quad 4 \%$

$\begin{array}{lll}1 & 2 & 8 \%\end{array}$

$214 \%$

\begin{tabular}{lll}
4 & 3 & $12 \%$ \\
\hline & 16 & $04 \%$
\end{tabular}

$\begin{array}{lll}5 & 16 & 64 \%\end{array}$
$0 \%$

$0 \%$

$1144 \%$

$4 \quad 16 \%$ 
$21 / 04 / 2015$

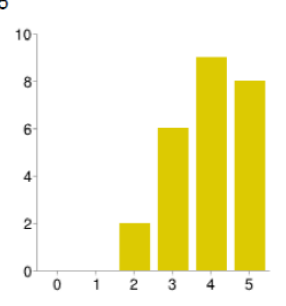

Pesquisa acadêmica sobre Processo de Negócio - Formulários Google

$$
\begin{array}{llr}
0 & 0 & 0 \% \\
1 & 0 & 0 \% \\
2 & 2 & 8 \% \\
3 & 6 & 24 \% \\
4 & 9 & 36 \% \\
5 & 8 & 32 \%
\end{array}
$$
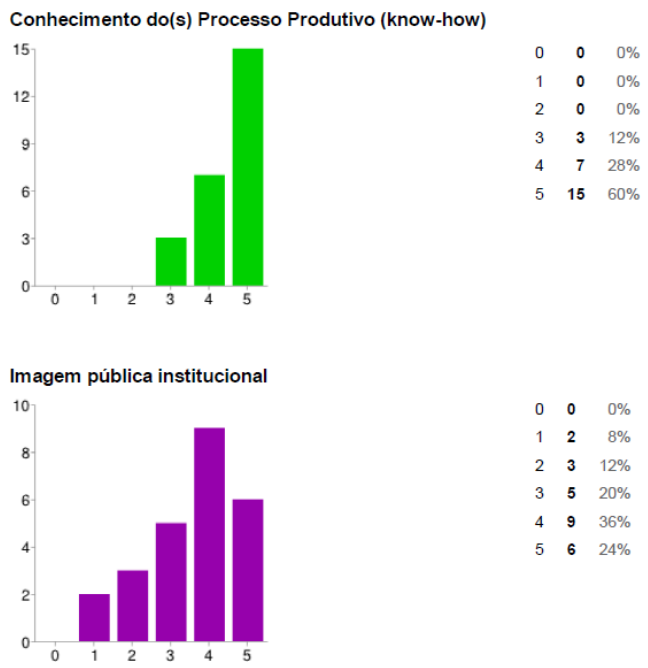

Para interferir num Processo de Negócio, defina o grau de relevância dos seguintes itens.

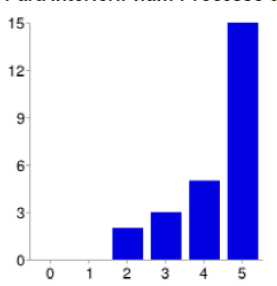

$000 \%$

$\begin{array}{lll}1 & 0 & 0 \%\end{array}$

$228 \%$

$33 \quad 12 \%$

$\begin{array}{rrr}4 & 5 & 20 \% \\ 5 & 15 & 60 \%\end{array}$

Reescrever e fazer conhecer novas regras e papéis

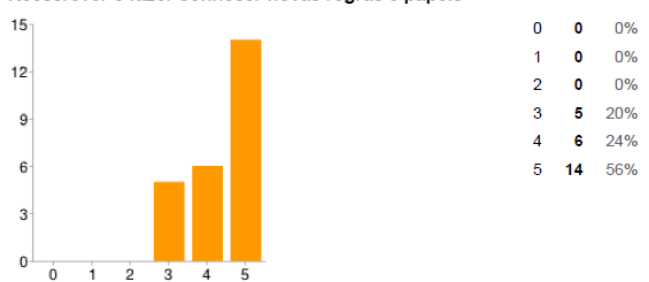

Criar um sistema/novo de workflow e GED 

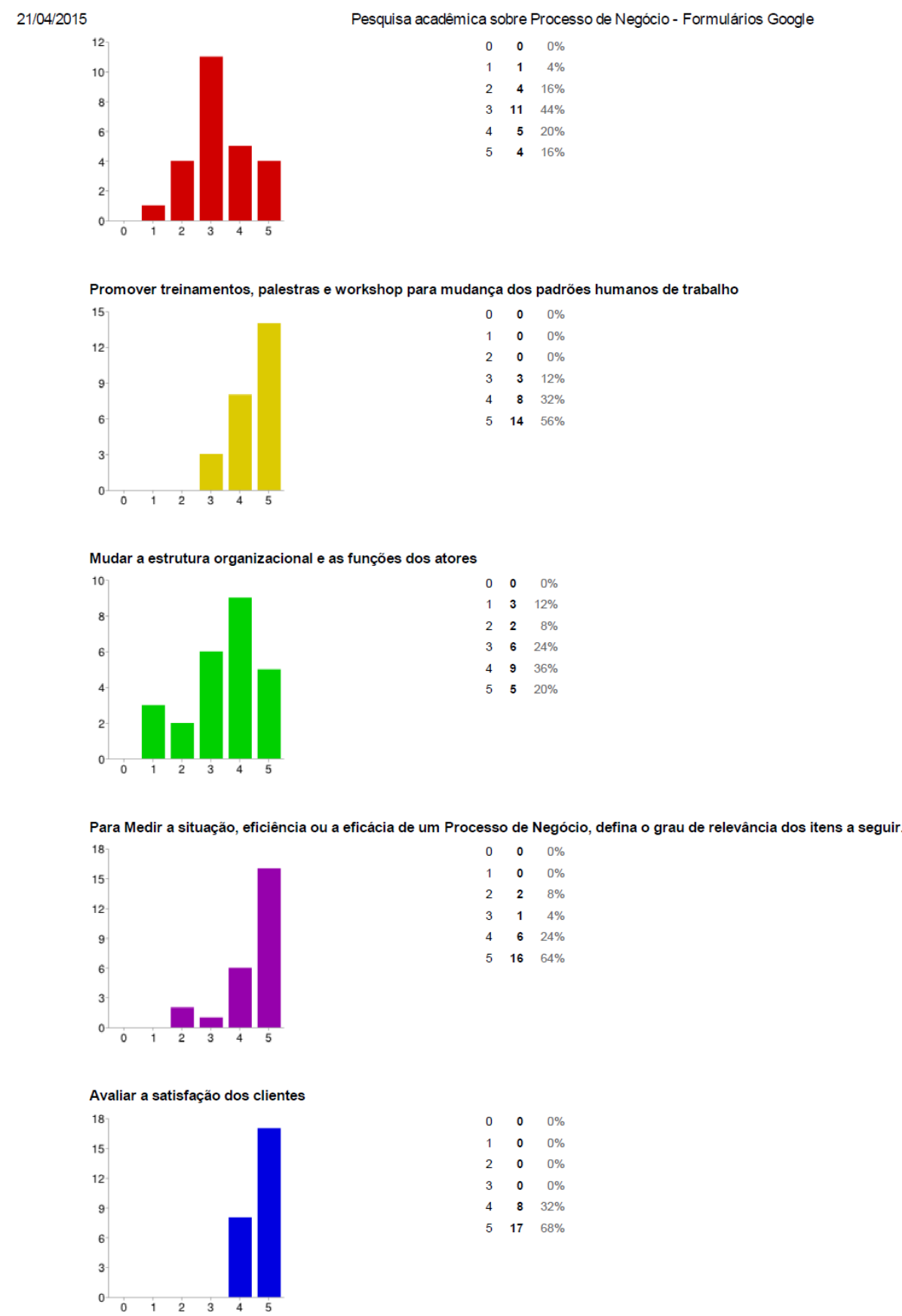

Promover reuniöes com os colaboradores e dialogar sobre o desempenho dos processos 

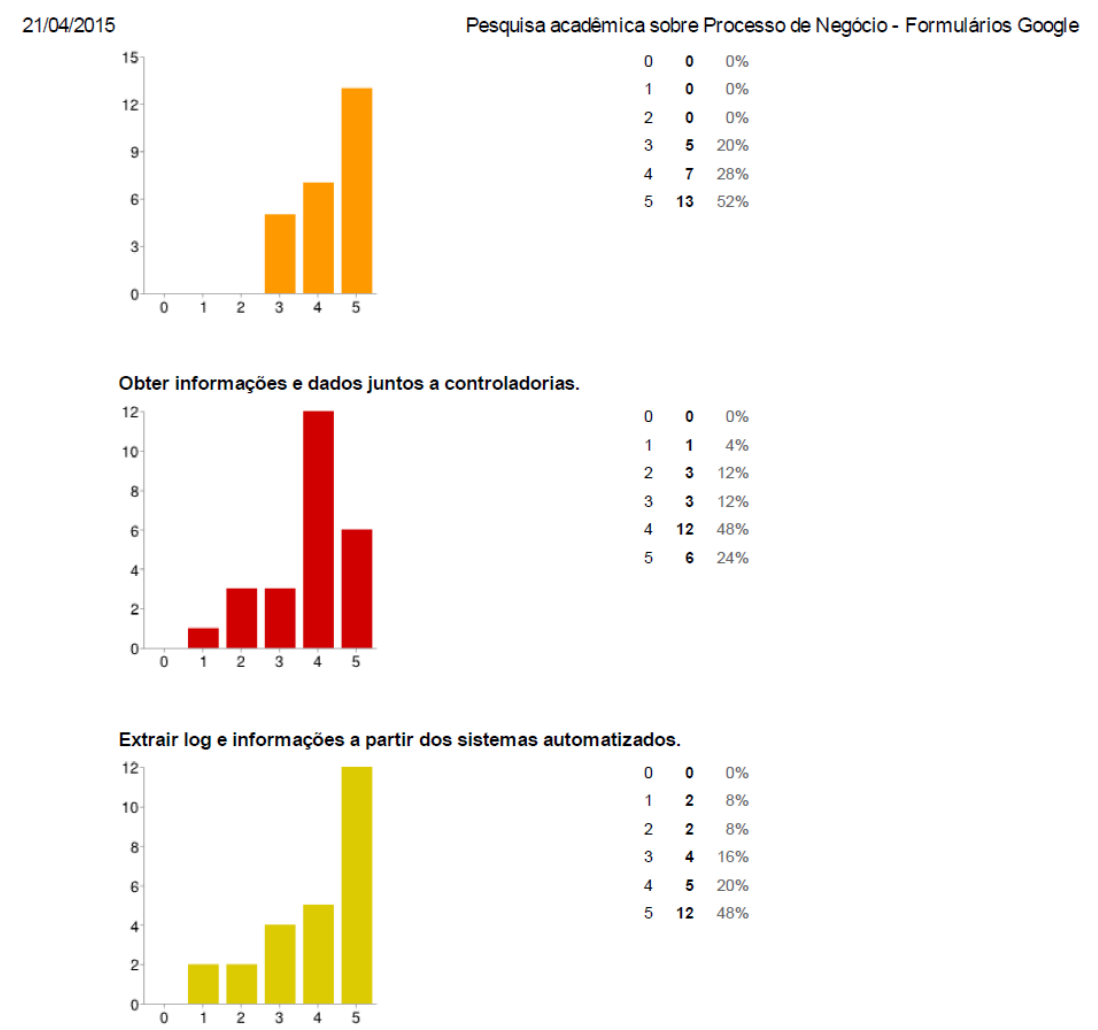

Número de respostas diárias

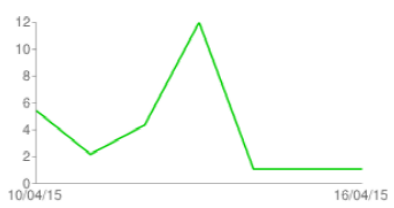


O texto pode ser utilizado para fins didáticos e científicos, sempre citando a fonte.

Contatos com o autor:

reginaldosilveiracosta@gmail.com

Brasília

2015 